In cooperation with the Goliad County Groundwater Conservation District, the Victoria County Groundwater Conservation District, the Pecan Valley Groundwater Conservation District, the Guadalupe-Blanco River Authority, and the San Antonio River Authority

\title{
Streamflow, Groundwater Hydrology, and Water Quality in the Upper Coleto Creek Watershed in Southeast Texas, 2009-10
}

Scientific Investigations Report 2011-5157 
Cover. Coleto Creek near Schroeder, Texas. Photograph by U.S. Geological Survey personnel. 


\section{Streamflow, Groundwater Hydrology, and Water Quality in the Upper Coleto Creek Watershed in Southeast Texas, 2009-10}

By Christopher L. Braun and Rebecca B. Lambert

In cooperation with the Goliad County Groundwater Conservation District, the Victoria County Groundwater Conservation District, the Pecan Valley Groundwater Conservation District, the Guadalupe-Blanco River Authority, and the San Antonio River Authority

Scientific Investigations Report 2011-5157 


\title{
U.S. Department of the Interior \\ KEN SALAZAR, Secretary \\ U.S. Geological Survey \\ Marcia K. McNutt, Director
}

\author{
U.S. Geological Survey, Reston, Virginia: 2011
}

For more information on the USGS - the Federal source for science about the Earth, its natural and living resources, natural hazards, and the environment, visit http://www.usgs.gov or call 1-888-ASK-USGS.

For an overview of USGS information products, including maps, imagery, and publications, visit http://www.usgs.gov/pubprod

To order this and other USGS information products, visit http://store.usgs.gov

Any use of trade, product, or firm names is for descriptive purposes only and does not imply endorsement by the U.S. Government.

Although this report is in the public domain, permission must be secured from the individual copyright owners to reproduce any copyrighted materials contained within this report.

Suggested citation:

Braun, C.L., and Lambert, R.B., 2011, Streamflow, groundwater hydrology, and water quality in the upper Coleto Creek watershed in southeast Texas, 2009-10: U.S. Geological Survey Scientific Investigations Report 2011-5157, 53 p. 


\section{Contents}

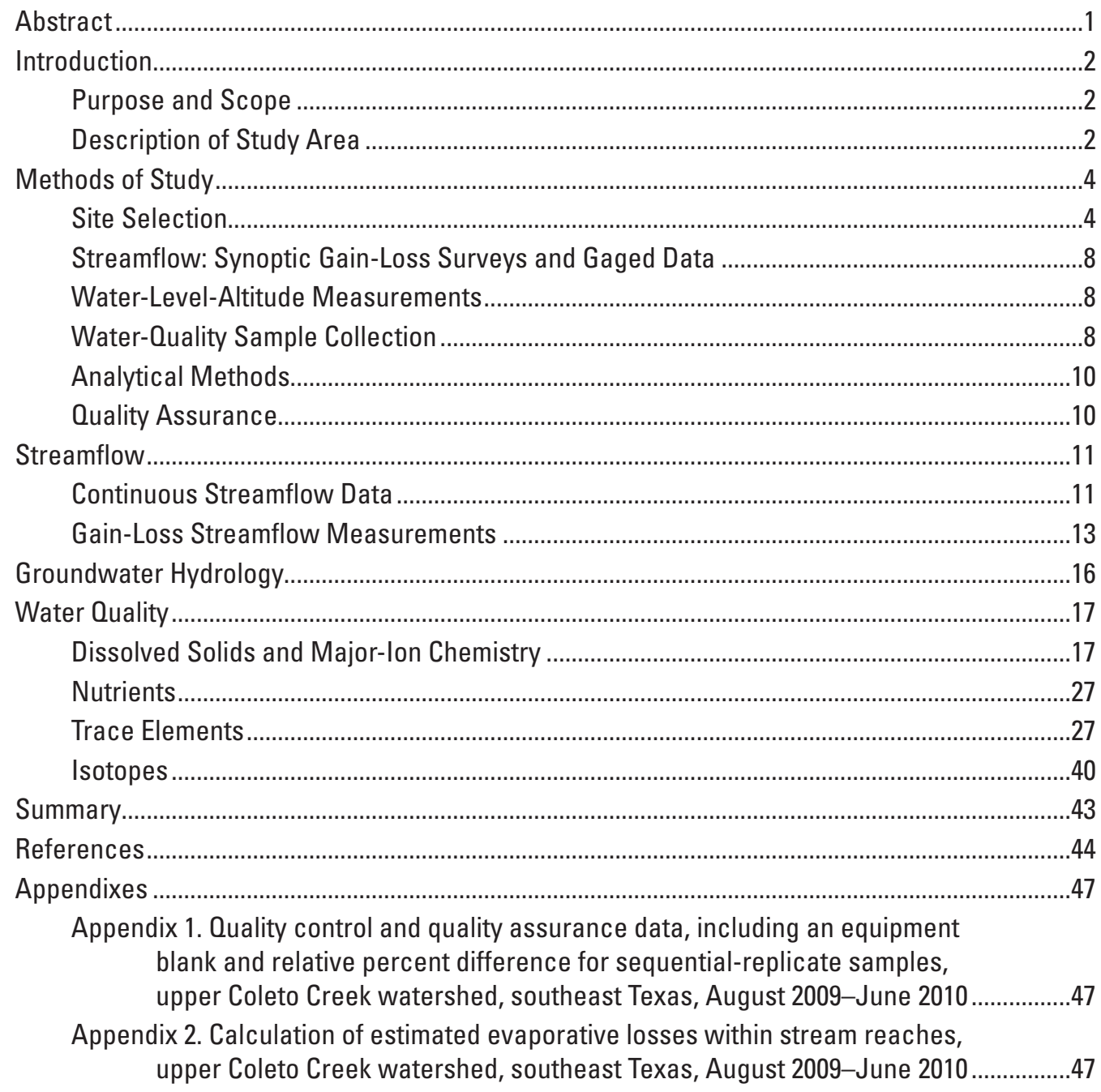




\section{Figures}

1. Map showing location of study area.

2. Diagram showing geologic and hydrogeologic units of the Texas coastal lowlands aquifer system in the upper Coleto Creek watershed in southeast Texas

3. Map showing hydrogeologic units in the upper Coleto Creek watershed, southeast Texas.

4. Map showing locations of all sites where samples were collected or measurements were made in the upper Coleto Creek watershed, southeast Texas

5. Graphs showing measured daily mean streamflow at U.S. Geological Survey streamflow-gaging stations 08176900 Coleto Creek at Arnold Road Crossing near Schroeder, Texas; 08177300 Perdido Creek at Farm Road 622 near Fannin, Texas; precipitation data measured at National Weather Service meteorological station 411880 Coleto Creek Reservoir; and measured watersurface elevations at USGS station 08177400 Coleto Creek Reservoir near Victoria, Texas, June 1, 2009-June 30, 2010.

6. Map showing location of stream reaches, U.S. Geological Survey streamflowmeasurement sites, streamflow-gaging stations, reservoir-stage gaging station, inflows, and spring in the upper Coleto Creek watershed, southeast Texas.

7. Map showing potentiometric surface of the Evangeline aquifer in the upper Coleto Creek watershed, southeast Texas, August 2009

8. Map showing potentiometric surface of the Evangeline aquifer in the upper Coleto Creek watershed, southeast Texas, January 2010

9. Map showing potentiometric surface of the Evangeline aquifer in the upper Coleto Creek watershed, southeast Texas, June 2010.

10. Map showing comparison of potentiometric contours of the Evangeline aquifer in the upper Coleto Creek watershed, southeast Texas, during three synoptic measurement events, August 2009, January 2010, and June 2010

11. Trilinear diagrams showing composition of surface water, groundwater, and spring water in the upper Coleto Creek watershed, southeast Texas, August 2009, January 2010, and June 2010

12. Stiff diagrams showing composition of surface water, groundwater, and spring water in the upper Coleto Creek water-shed, southeast Texas, August 2009, January 2010, and June 2010.

13. Map showing nitrate concentrations (as nitrogen) in surface water, groundwater, and spring water in the upper Coleto Creek watershed, southeast Texas, August 2009, January 2010, and June 2010.

14. Graphs showing relation between delta oxygen-18 and delta deuterium in samples collected from selected surface-water, groundwater, and spring sites in the upper Coleto Creek watershed, southeast Texas, August 2009, January 2010, and June 2010.

15. Graph showing relation between the inverse of strontium concentrations and delta strontium-87 in samples collected from surface-water, groundwater, and spring sites in the upper Coleto Creek watershed, southeast Texas, August 2009, January 2010, and June 2010. 


\section{Tables}

1. Description of surface-water sites in the upper Coleto Creek watershed,

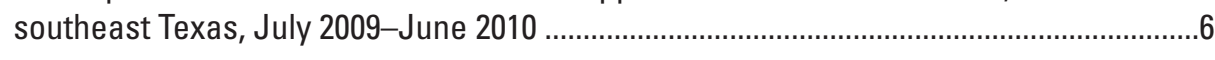

2. Description of groundwater and spring sites in the upper Coleto Creek watershed, southeast Texas, August 2009-June 2010.

3. Rainfall data obtained from National Weather Service meteorological stations in and near the upper Coleto Creek watershed, southeast Texas, during June 1, 2009-August 12, 2009.

4. Summary of streamflow-measurement results, measurement error ratings, and potential measurement errors for reaches along Coleto Creek and contributing streams during streamflow-measurement surveys in July 2009, January 2010, and June 2010, upper Coleto Creek watershed, southeast Texas ............18

5. Gain-loss determinations for reaches along Coleto Creek and contributing streams during three streamflow-measurement surveys in July 2009, January 2010, and June 2010, upper Coleto Creek watershed, southeast Texas ............20

6. Groundwater-level altitude measurements at selected wells in the upper Coleto Creek watershed, southeast Texas, August 2009-June 2010

7. Water-quality data collected from surface-water, groundwater, and spring sites, upper Coleto Creek watershed, southeast Texas, August 2009-June 2010

\section{Conversion Factors, Datums, Water-Quality Units, and Nomenclature}

\begin{tabular}{lcl}
\hline \multicolumn{1}{c}{ Multiply } & By & \multicolumn{1}{c}{ To obtain } \\
\hline inch (in.) & Length & \\
foot $(\mathrm{ft})$ & 25.4 & millimeter $(\mathrm{mm})$ \\
mile $(\mathrm{mi})$ & 0.3048 & meter $(\mathrm{m})$ \\
\hline & 1.609 & kilometer $(\mathrm{km})$ \\
\hline square $\mathrm{mile}^{\left(\mathrm{mi}^{2}\right)}$ & Area & \\
square mile $\left(\mathrm{mi}^{2}\right)$ & 259.0 & hectare $(\mathrm{ha})$ \\
\hline & 2.590 & square kilometer $\left(\mathrm{km}^{2}\right)$ \\
\hline liter $(\mathrm{L})$ & Volume & \\
acre-foot $($ acre-ft) & 0.2642 & gallon $(\mathrm{gal})$ \\
\hline & 1,233 & cubic meter $\left(\mathrm{m}^{3}\right)$ \\
\hline cubic foot per second $\left(\mathrm{ft}^{3} / \mathrm{s}\right)$ & Flow rate & \\
\hline
\end{tabular}

Temperature in degrees Celsius $\left({ }^{\circ} \mathrm{C}\right)$ might be converted to degrees Fahrenheit $\left({ }^{\circ} \mathrm{F}\right)$ as follows:

${ }^{\circ} \mathrm{F}=\left(1.8 \mathrm{x}^{\circ} \mathrm{C}\right)+32$

Temperature in degrees Fahrenheit $\left({ }^{\circ} \mathrm{F}\right)$ might be converted to degrees Celsius $\left({ }^{\circ} \mathrm{C}\right)$ as follows:

${ }^{\circ} \mathrm{C}=\left({ }^{\circ} \mathrm{F}-32\right) / 1.8$ 


\section{Datums}

Horizontal coordinate information is referenced to the North American Datum of 1983 (NAD 83). Vertical coordinate information is referenced to the North American Vertical Datum of 1988 (NAVD 88).

Altitude, as used in this report, refers to distance above the vertical datum.

\section{Water-Quality Units}

Specific conductance is given in microsiemens per centimeter at 25 degrees Celsius $(\mu \mathrm{S} / \mathrm{cm})$.

Concentration of chemical constituents in water are given either in milligrams per liter (mg/L) or micrograms per liter $(\mu \mathrm{g} / \mathrm{L})$.

\section{Isotope Units}

Per mil: A unit expressing the ratio of stable-isotope abundances of an element in a sample to those of a standard material. Per mil units are equivalent to parts per thousand. Stable-isotope ratios, also known as delta values, are computed as follows (Kendall and McDonnell, 1998):

$$
\delta \mathrm{X}=\left[\left(\mathrm{R}_{\text {sample }}-\mathrm{R}_{\text {standard }}\right) / \mathrm{R}_{\text {standard }}\right] \times 1,000
$$

where

$$
\begin{aligned}
& \delta=\text { delta, } \\
& \mathrm{X}=\text { heavier stable isotope, and } \\
& \mathrm{R}=\text { ratio of rare (heavier) isotope to common (lighter) isotope in sample or standard. }
\end{aligned}
$$

The $\delta$ values for stable-isotope ratios discussed in this report are referenced to the following standard materials:

\begin{tabular}{lcc}
\hline Element & R & Standard identity and reference \\
\hline Hydrogen & Hydrogen-2/hydrogen-1 & $\begin{array}{c}\text { Vienna Standard Mean Ocean Water (Craig, 1961; } \\
\text { Gonfiantini, 1984) }\end{array}$ \\
Oxygen & Oxygen-18/oxygen-16 & $\begin{array}{c}\text { Vienna Standard Mean Ocean Water (Craig, 1961; } \\
\text { Gonfiantini, 1984) }\end{array}$ \\
\hline
\end{tabular}




\title{
Streamflow, Groundwater Hydrology, and Water Quality in the Upper Coleto Creek Watershed in Southeast Texas, 2009-10
}

\author{
By Christopher L. Braun and Rebecca B. Lambert
}

\section{Abstract}

The U.S. Geological Survey (USGS), in cooperation with the Goliad County Groundwater Conservation District, Victoria County Groundwater Conservation District, Pecan Valley Groundwater Conservation District, Guadalupe-Blanco River Authority, and San Antonio River Authority, did a study to examine the hydrology and stream-aquifer interactions in the upper Coleto Creek watershed. Findings of the study will enhance the scientific understanding of the study-area hydrology and be used to support water-management decisions to help ensure protection of the Evangeline aquifer and surface-water resources in the study area. This report describes the results of streamflow measurements, groundwater-level measurements, and water quality (from both surface-water and groundwater sites) collected from three sampling events (July-August 2009, January 2010, and June 2010) designed to characterize groundwater (from the Evangeline aquifer) and surface water, and the interaction between them, in the upper Coleto Creek watershed upstream from Coleto Creek Reservoir in southeast Texas. This report also provides a baseline level of water quality for the upper Coleto Creek watershed.

Three surface-water gain-loss surveys-July 29-30, 2009, January 11-13, 2010, and June 21-22, 2010 -were done under differing hydrologic conditions to determine the locations and amounts of streamflow recharging or discharging from the Evangeline aquifer. During periods when flow in the reaches of the upper Coleto Creek watershed was common (such as June 2010, when 12 of 25 reaches were flowing) or probable (such as January 2010, when 22 of 25 reaches were flowing), most of the reaches appeared to be gaining ( 86 percent in January 2010 and 92 percent in June 2010); however, during drought conditions (July 2009), streamflow was negligible in the entire upper Coleto Creek watershed; streamflow was observed in only two reaches during this period, one that receives inflow directly from Audilet Spring and another reach immediately downstream from Audilet Spring. Water levels in the aquifer at this time declined to the point that the aquifer could no longer provide sufficient water to the streams to sustain flow.
Groundwater-level altitudes were measured at as many as 33 different wells in the upper Coleto Creek watershed during three different survey events: August 4-7 and 12, 2009; January 12-14 and 22, 2010; and June 21-24, 2010. These data were used in conjunction with groundwater-level altitudes from three continuously monitored wells to generate potentiometric surface maps for each of the three sampling events to help characterize the groundwater hydrology of the Evangeline aquifer. The altitudes of potentiometric surface contours from all three sampling events are highest in the northeast part of the study area and lowest in the southwest part of the study area. Groundwater flow direction shifts from southeast to east across the watershed, roughly coinciding with the general flow direction of the main stem of Coleto Creek. Groundwaterlevel altitudes increased an average of 2.35 inches between the first and third sampling events as drought conditions in summer 2009 were followed by consistent rains the subsequent fall and winter, an indication that the aquifer responds relatively quickly to both the absence and relative abundance of precipitation.

A total of 44 water-quality samples were collected at 21 different sites over the course of the three sampling events (August 4-7, 2009, January 12-14, 2010, and June 21-24, 2010). In most cases, samples from each site were analyzed for the following constituents: dissolved solids, major ions, alkalinity, nutrients, trace elements, and stable isotopes (hydrogen, oxygen, and strontium). Major-ion compositions were relatively consistent among most of the samples from the upper Coleto Creek watershed (generally calcium bicarbonate waters, with chloride often making a major contribution). Of the 23 trace elements that were analyzed in water samples as part of this study, only arsenic (in two samples) and manganese (in seven samples) had concentrations that exceeded public drinking-water standards or guidelines. At 3 of the 19 sites sampled-State wells 79-06-411, 79-14-204, and Audilet Spring - nitrate concentrations exceeded the threshold (2.0 milligrams per liter) associated with anthropogenic contributions. The majority of the water samples (36 out of 44) that were analyzed for stable isotopes of hydrogen and oxygen during the three sampling events plotted in a relatively tight cluster centered near the global meteoric water line. The 
eight remaining samples, which include the four surface-water samples collected in June 2010, the sample collected from Coleto Creek Reservoir in January 2010, and all three samples collected at State well 79-15-904, deviate from the global meteoric water line in a way that indicates evaporative losses. The isotopic signatures of the three samples collected at State well 79-15-904, when taken in conjunction with its proximity to Coleto Creek Reservoir, indicate that there is likely a hydraulic connection between the two. When all of the sites are examined as a whole, there is a general pattern in strontium concentrations across the entire watershed that indicates that both the surface-water and groundwater samples derive from a single source (the Evangeline aquifer) with relatively uniform water-rock interactions.

\section{Introduction}

The U.S. Geological Survey (USGS), in cooperation with the Goliad County Groundwater Conservation District (GCGCD), Victoria County Groundwater Conservation District (VCGCD), Pecan Valley Groundwater Conservation District (PVGCD), Guadalupe-Blanco River Authority (GBRA), and San Antonio River Authority (SARA), did a study to examine the hydrology and stream-aquifer interactions in the upper Coleto Creek watershed (fig. 1). Findings of the study will enhance the scientific understanding of the study-area hydrology and be used to support water-management decisions for the Evangeline aquifer and surface-water resources in the study area.

The data documented in this report will provide baseline information to address different hydrologic and water-quality issues in a coastal study area undergoing changes in land use, such as possible streambank erosion, loss of wetlands, subsidence, saltwater intrusion, problems associated with excessive nutrients, disease-causing microorganisms, and toxic chemicals originating from industrial activities or mining practices.

\section{Purpose and Scope}

The purpose of this report is to describe streamflow, groundwater-level altitudes, and water quality (from both surface-water and groundwater sites) from three sampling events (July-August 2009, January 2010, and June 2010) in order to characterize surface water, groundwater from the Evangeline aquifer, and the interaction between them, in the upper Coleto Creek watershed upstream from Coleto Creek Reservoir in southeast Texas.

\section{Description of Study Area}

The upper Coleto Creek watershed (fig. 1) is mostly rural and, like other areas of Texas, is experiencing population growth (U.S. Census Bureau, 2011); as a whole, the three counties that make up the study area (De Witt, Goliad, and Victoria) experienced slightly less than a 3 percent population increase between 2000 and 2009. The upper Coleto Creek watershed starts about 12 miles (mi) northwest of Yorktown and ends at Coleto Creek Reservoir. Coleto Creek Reservoir, which is used primarily to provide cooling water for electric power generation, is about $12 \mathrm{mi}$ southwest of Victoria on Coleto and Perdido Creeks and impounds runoff from 507 square miles $\left(\mathrm{mi}^{2}\right)$ of drainage area (Guadalupe-Blanco River Authority, 2007). Conservation storage for the reservoir is 31,040 acre-feet (Texas Water Development Board, 2011).

The upper Coleto Creek watershed overlies the Texas coastal lowlands aquifer system (Chicot, Evangeline, and Jasper aquifers). The Texas coastal lowlands aquifer system is equivalent to the Gulf Coast aquifer system (Ashworth and Hopkins 1995; Kasmarek and Robinson, 2004). The Texas coastal lowlands aquifer system is composed of formations from Oligocene through Holocene age (fig. 2) that dip and thicken toward the Gulf of Mexico. The sediments composing the Texas coastal lowlands aquifer system consist of overlapping mixtures of sand, silt, and clay deposited and reworked by numerous oscillations of ancient shorelines (Ryder, 1996; Lizárraga and Ockerman, 2010). The Jasper aquifer crops out (that is, becomes exposed at land surface) in the northwest corner of the study area; the following hydrogeologic units crop out successively towards the southeast corner of the study area: Burkeville confining unit, Evangeline aquifer, and Chicot aquifer (fig. 3). Geologic units corresponding with each hydrogeologic unit are shown in figure 2 .

The Evangeline aquifer, which is the principal aquifer of interest in this study, is typically wedge shaped (because it dips and thickens toward the coast) and has a high sand-clay ratio; it contains individual sand beds that are characteristically tens of feet thick (Baker, 1979). The aquifer ranges in thickness from 400 to 1,000 feet (ft) where it crops out (the surface expression is shown in fig. 3). Near the coastline, where the top of the aquifer is about $1,000 \mathrm{ft}$ deep, its thickness averages about 2,000 ft (Baker, 1979). The Evangeline is considered one of the most prolific producing aquifers in the Texas Coastal Plain and is known for its abundance of goodquality groundwater (Baker, 1979).

The climate of the study area is described as subtropical humid and is characterized by warm summers and mild winters (Larkin and Bomar, 1983). Heaviest precipitation tends to occur in late spring to early summer and in the fall (Texas Water Development Board, 2007); droughts and floods are common. 


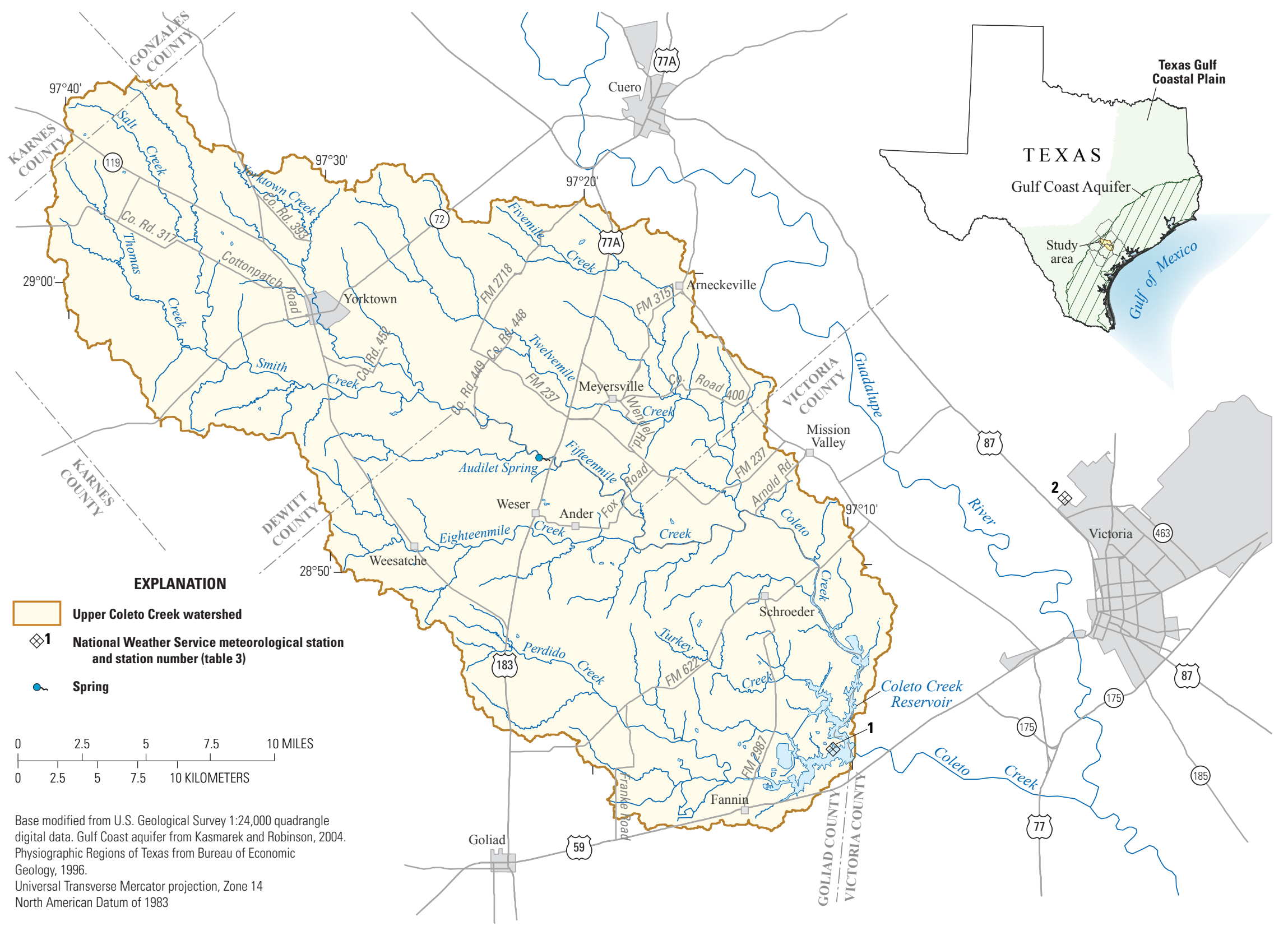

Figure 1. Location of study area. 


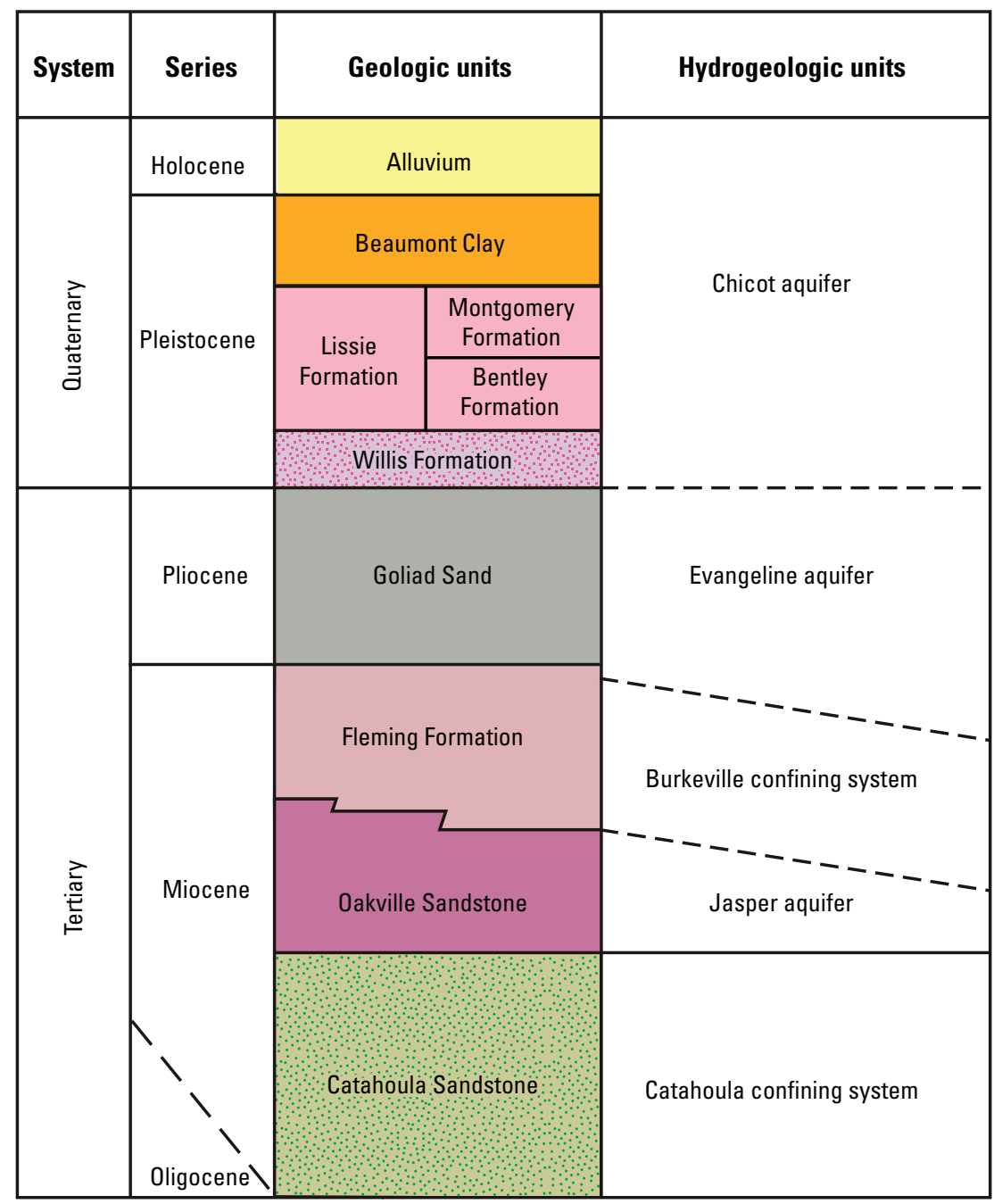

Figure 2. Geologic and hydrogeologic units of the Texas coastal lowlands aquifer system in the upper Coleto Creek watershed in southeast Texas (modified from Baker, 1979, table 1, and Mace and others, 2006, fig. 2-12).

\section{Methods of Study}

\section{Site Selection}

Surface-water sites were selected as part of the initial, broad-based inventory (table 1, fig. 4) on the basis of their accessibility (typically adjacent to public roads, thereby eliminating the need for permission to access private land), position relative to where the Evangeline aquifer crops out, potential contribution to streamflow of the upper Coleto Creek watershed (larger, perennial streams were given priority over smaller, intermittent ones), and location within the study area relative to existing USGS streamflow-gaging stations and to the other surface-water sites identified during the inventory. A subset of the surface-water sites from the broad-based inventory was selected for the gain-loss survey. Sites were selected that provided the greatest potential for streamflow during variable (wet and dry) hydrologic conditions, as well as the most information regarding streamflow gains from or losses to the Evangeline aquifer. Sites at or just below the confluence of two streams, which were considered to be major contributors to streamflow in the study area, also were selected whenever possible. Surface-water sites were selected for water-quality analyses on the basis of potential for perennial flow and proximity to groundwater sites selected for water-quality analyses in order to allow for comparison of water quality between the two.

Available monitoring wells completed in the Evangeline aquifer in the study area were inventoried with assistance from the cooperating agencies (GCGCD, VCGCD, PVGCD, GBRA, SARA) to identify suitable wells for monitoring and water-quality sampling. Approximately 75 percent of the selected wells were within a 1-mi buffer zone around Coleto Creek and its major tributaries; a few additional wells along Perdido Creek were also identified. Information from the 


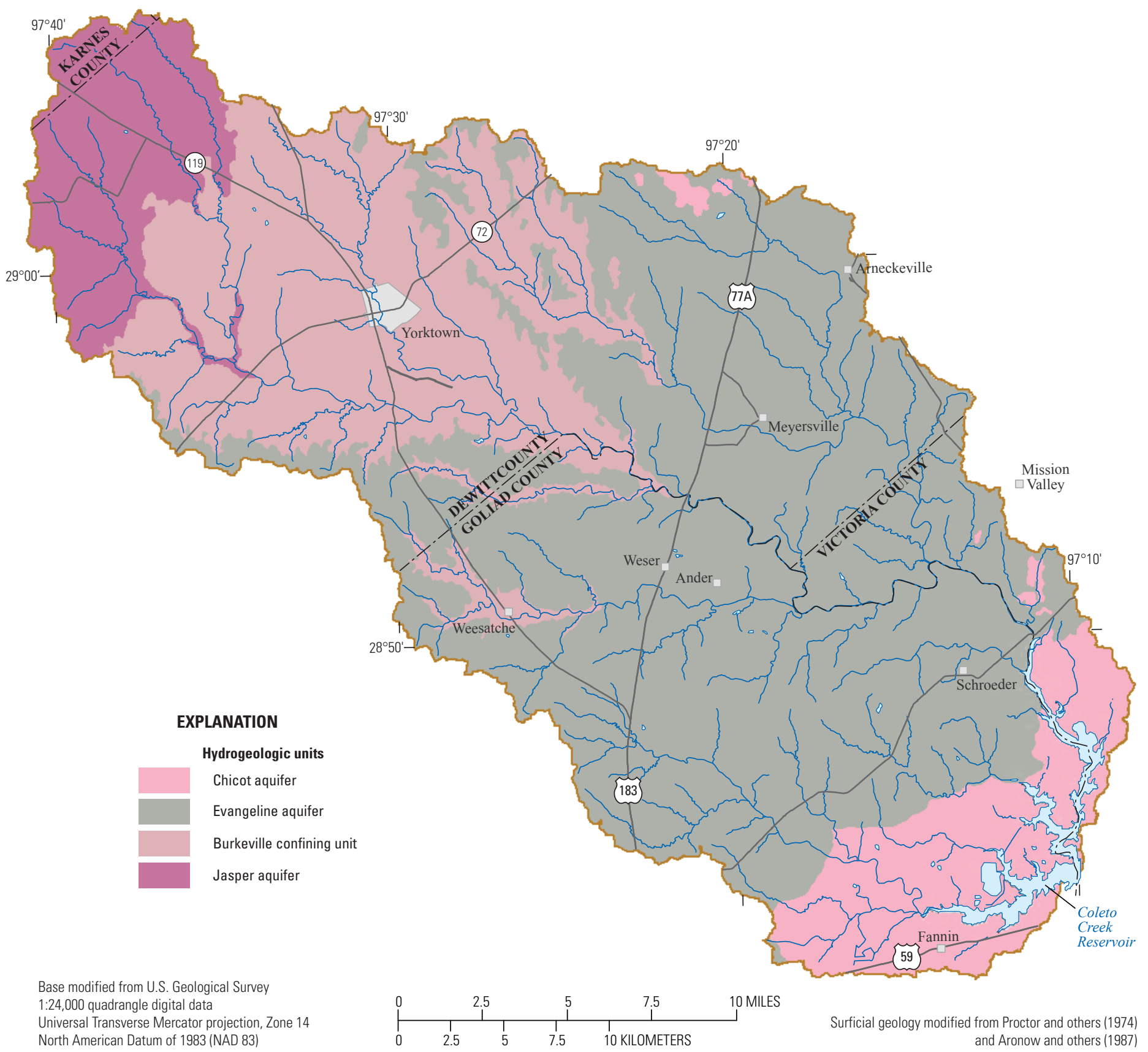

Figure 3. Hydrogeologic units in the upper Coleto Creek watershed, southeast Texas.

initial broad-based well inventory culminated in the selection of 37 existing State wells (fig. 4). Of the selected wells, four were chosen because of their proximity to each of the four surface-water sites selected for water-quality analyses, whereas some wells were selected because they were farther from streams and represented aquifer conditions that were less likely to be influenced by streamflow. Wells were also selected to provide a good spatial distribution across the study area. Both shallow and deep Evangeline aquifer wells were selected for the study. No wells were selected where the Jasper aquifer crops out in the northwest corner of the upper Coleto Creek watershed (fig. 3), because the Evangeline aquifer is absent in this area. Depth to water, well depth, discharge, general construction information, aquifer(s) penetrated, and location were determined for each of the wells inventoried whenever possible. This information was compiled, reviewed, and entered into the USGS National Water Information System (NWIS) database (U.S. Geological Survey, 2011). 
Table 1. Description of surface-water sites in the upper Coleto Creek watershed, southeast Texas, July 2009-June 2010.

[USGS, U.S. Geological Survey; x, measurement made; M, miscellaneous streamflow measurement site; C, continuous streamflow measurement site; R, reservoir-stage gaging station]

\begin{tabular}{|c|c|c|c|c|c|c|c|c|c|c|c|}
\hline \multirow{2}{*}{$\begin{array}{c}\text { Site } \\
\text { identifier } \\
\text { (figs. 4, 6, } \\
\text { 12-15) }\end{array}$} & \multirow{2}{*}{$\begin{array}{l}\text { USGS } \\
\text { station } \\
\text { number }\end{array}$} & \multirow[b]{2}{*}{ USGS station name } & \multirow[b]{2}{*}{$\begin{array}{l}\text { Site } \\
\text { type }\end{array}$} & \multirow[b]{2}{*}{ Data type } & \multirow[b]{2}{*}{ County } & \multicolumn{3}{|c|}{ Gain-loss survey } & \multicolumn{3}{|c|}{ Water-quality sampling } \\
\hline & & & & & & $\begin{array}{l}\text { July } \\
2009\end{array}$ & $\begin{array}{c}\text { January } \\
2010\end{array}$ & $\begin{array}{l}\text { June } \\
2010\end{array}$ & $\begin{array}{c}\text { August } \\
2009\end{array}$ & $\begin{array}{c}\text { January } \\
2010\end{array}$ & $\begin{array}{l}\text { June } \\
2010\end{array}$ \\
\hline 1 & 08176523 & Salt Creek at County Road 317 near Yorktown, Tex. & M & Streamflow & De Witt & $\mathrm{x}$ & $\mathrm{x}$ & $\mathrm{x}$ & & & \\
\hline 11 & 08176526 & Thomas Creek at Cottonpatch Road near Yorktown, Tex. & M & Streamflow & De Witt & $\mathrm{x}$ & $\mathrm{x}$ & $\mathrm{x}$ & & & \\
\hline 13 & 08176529 & Smith Creek at Highway 72 near Yorktown, Tex. & M & Streamflow & De Witt & $\mathrm{x}$ & $\mathrm{x}$ & $\mathrm{x}$ & & & \\
\hline 14 & 08176532 & Smith Creek at Highway 119 near Yorktown, Tex. & M & Streamflow & De Witt & $\mathrm{x}$ & $\mathrm{x}$ & $\mathrm{x}$ & & & \\
\hline 2 & 08176535 & Yorktown Creek at County Road 393 near Yorktown, Tex. & M & Streamflow & De Witt & $\mathrm{x}$ & $\mathrm{x}$ & $\mathrm{x}$ & & & \\
\hline 12 & 08176538 & Yorktown Creek at Highway 72 at Yorktown, Tex. & M & Streamflow & De WItt & $\mathrm{x}$ & $\mathrm{x}$ & $\mathrm{x}$ & & & \\
\hline 23 & 08176540 & Yorktown Creek at County Road 452 near Yorktown, Tex. & M & Streamflow & De Witt & $\mathrm{x}$ & $\mathrm{x}$ & $\mathrm{x}$ & & $\mathrm{x}$ & $\mathrm{x}$ \\
\hline 26 & 08176544 & Fifteenmile Creek at County Road 449 Road near Ander, Tex. & M & Streamflow & Goliad & $\mathrm{x}$ & $\mathrm{x}$ & $\mathrm{x}$ & & & \\
\hline 44 & 08176548 & Fifteenmile Creek at Audilet Crossing near Ander, Tex. & M & Streamflow & DeWitt & & $\mathrm{x}$ & & & & \\
\hline 46 & 08176550 & Fifteenmile Creek near Weser, Tex. & M & Streamflow & DeWitt & $\mathrm{x}$ & $\mathrm{x}$ & $\mathrm{x}$ & & & \\
\hline 76 & 08176555 & Fifteenmile Creek at Fox Road near Ander, Tex. & M & Streamflow & Goliad & $\mathrm{x}$ & $\mathrm{x}$ & $\mathrm{x}$ & & & \\
\hline 62 & 08176565 & Eighteenmile Creek at Highway 119 at Weesatche, Tex. & M & Streamflow & Goliad & $\mathrm{x}$ & $\mathrm{x}$ & $\mathrm{x}$ & & & \\
\hline 70 & 08176580 & Eighteenmile Creek at Highway 77A/183 near Ander, Tex. & M & Streamflow & Goliad & $\mathrm{x}$ & $\mathrm{x}$ & $\mathrm{x}$ & & & \\
\hline 80 & 08176590 & Fifteenmile Creek below Eighteenmile Creek near Ander, Tex. & M & Streamflow & Goliad & & $\mathrm{x}$ & $\mathrm{x}$ & & $\mathrm{x}$ & $\mathrm{x}$ \\
\hline 79 & 08176592 & Fifteenmile Creek near Ander, Tex. & M & Streamflow & Goliad & $\mathrm{x}$ & $\mathrm{x}$ & & & & \\
\hline 20 & 08176594 & Twelvemile Creek at Farm Road 2718 near Yorktown, Tex. & M & Streamflow & De Witt & $\mathrm{x}$ & $\mathrm{x}$ & $\mathrm{x}$ & & & \\
\hline 34 & 08176596 & Twelvemile Creek at Highway 77A/183 near Meyersville, Tex. & M & Streamflow & De Witt & $\mathrm{x}$ & $\mathrm{x}$ & $\mathrm{x}$ & & & \\
\hline 51 & 08176598 & Twelvemile Creek at Wendel Road near Meyersville, Tex. & M & Streamflow & De Witt & $\mathrm{x}$ & $\mathrm{x}$ & $\mathrm{x}$ & & & \\
\hline 9 & 08176599 & Fivemile Creek at Highway 77A/183 near Arneckville, Tex. & M & Streamflow & De Witt & $\mathrm{x}$ & $\mathrm{x}$ & $\mathrm{x}$ & & & \\
\hline 32 & 08176675 & Fivemile Creek at Farm Road 3157 near Arneckville, Tex. & M & Streamflow & De Witt & $\mathrm{x}$ & $\mathrm{x}$ & $\mathrm{x}$ & & & \\
\hline 37 & 08176750 & Fivemile Creek at County Road 400 near Meyersville, Tex. & M & Streamflow & De Witt & $\mathrm{x}$ & $\mathrm{x}$ & $\mathrm{x}$ & & & \\
\hline 55 & 08176825 & Twelvemile Creek at Farm Road 237 near Mission Valley, Tex. & M & Streamflow & Victoria & $\mathrm{x}$ & $\mathrm{x}$ & $\mathrm{x}$ & & & \\
\hline 90 & 08176900 & Coleto Creek at Arnold Road Crossing near Schroeder, Tex. & $\mathrm{C}$ & Streamflow & Goliad & $\mathrm{x}$ & $\mathrm{x}$ & $\mathrm{x}$ & & $\mathrm{x}$ & $\mathrm{x}$ \\
\hline 97 & 08177000 & Coleto Creek near Schroeder, Tex. & M & Streamflow & Victoria & $\mathrm{x}$ & $\mathrm{x}$ & $\mathrm{x}$ & & & \\
\hline 99 & 08177270 & Turkey Creek at Farm Road 2987 near Fannin, Tex. & M & Streamflow & Goliad & $\mathrm{x}$ & $\mathrm{x}$ & $\mathrm{x}$ & & & \\
\hline 87 & 08177300 & Perdido Creek at Farm Road 622 near Fannin, Tex. & $\mathrm{C}$ & Streamflow & Goliad & $\mathrm{x}$ & $\mathrm{x}$ & $\mathrm{x}$ & & $\mathrm{x}$ & $\mathrm{x}$ \\
\hline 101 & 08177310 & Perdido Creek at Franke Road near Fannin, Tex. & M & Streamflow & Goliad & $\mathrm{x}$ & & & & & \\
\hline 104 & 08177350 & Perdido Creek at Farm Road 2987 near Fannin, Tex. & M & Streamflow & Goliad & $\mathrm{x}$ & $\mathrm{x}$ & $\mathrm{x}$ & & & \\
\hline 106 & 08177400 & Coleto Creek Reservoir near Victoria, Tex. & $\mathrm{R}$ & Reservoir stage & Victoria & $\mathrm{x}$ & $\mathrm{x}$ & $\mathrm{x}$ & & $\mathrm{x}$ & \\
\hline
\end{tabular}




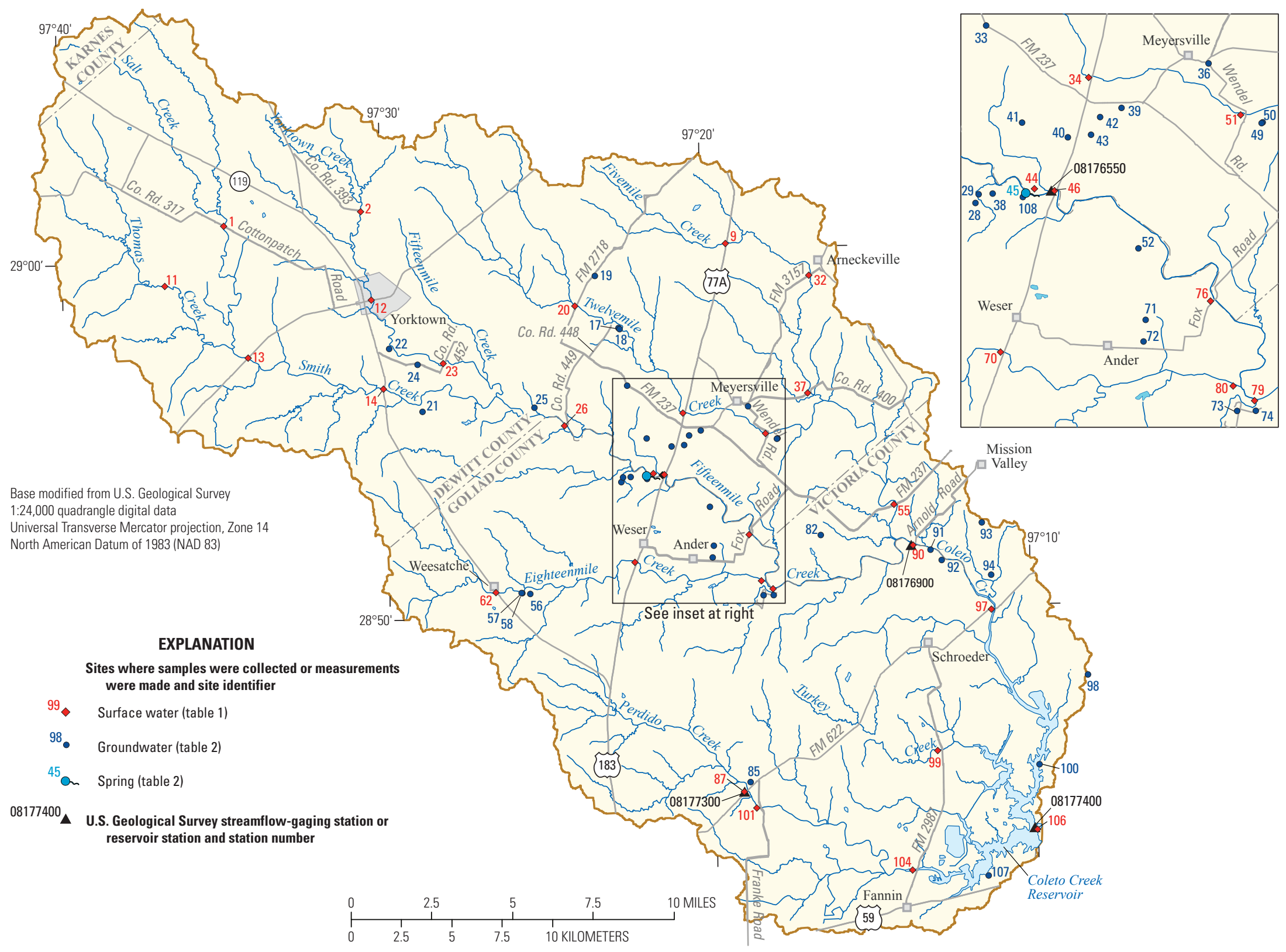

Figure 4. Locations of all sites where samples were collected or measurements were made in the upper Coleto Creek watershed, southeast Texas. 
Streamflow, Groundwater Hydrology, and Water Quality in the Upper Coleto Creek Watershed in Southeast Texas

\section{Streamflow: Synoptic Gain-Loss Surveys and Gaged Data}

Three surface-water gain-loss surveys were done in different seasons with differing hydrologic conditions - summer 2009 (July 29-30), winter 2010 (January 11-13), and again in summer 2010 (June 21-22) - to more accurately determine the seasonal variation, locations, and magnitude of stream-aquifer interaction. Methods used to measure streamflow (discharge) amounts during each gain-loss survey are described in detail by Rantz and others (1982). The results of the gain-loss assessments in this study are intended to provide initial information to improve the understanding of the study-area hydrology, but these results will not be adequate for broad characterization of gaining and losing streamflow over all hydrologic regimes, nor can they be extrapolated over time. Synoptic streamflow measurements were made at 25 surface-water measurement sites during each of the three gain-loss surveys (table 1, fig. 4). Streamflow measurements were made in one or two of the three gain-loss surveys at three alternate measurement sites (USGS stations 08176548 Fifteenmile Creek at Audilet Crossing near Ander, Tex., 08176590 Fifteenmile Creek below Eighteenmile Creek near Ander, Tex., and 08177310 Perdido Creek at Franke Road near Fannin, Tex.). These alternate sites were used to verify results collected at the primary sites or as a check for flow in a site upstream from a primary site that had no flow. Streamflow measurements were made in two of the three gain-loss surveys at one site (USGS station 08176592 Fifteenmile Creek near Ander, Tex.).

Streamflow data collected during June 1, 2009-June 30, 2010, from two USGS streamflow-gaging stations in the upper Coleto Creek watershed (08176900 Coleto Creek at Arnold Road Crossing near Schroeder, Tex. [hereinafter station 08176900 on Coleto Creek] and 08177300 Perdido Creek at Farm Road 622 near Fannin, Tex. [hereinafter station 08177300 on Perdido Creek]) provided additional data points (for the time periods between gain-loss surveys) for the assessment of gaining and losing reaches. Streamflow measurements were made about every 2 months during the study at the two streamflow-gaging stations, and continuous streamflow records are computed from the stage, or gage height, which is measured every 60 minutes by using a pressure transducer or radar equipment. An analysis of potential measurement error for the rated streamflow values has been included in the gain-loss calculations that include rated streamflow from existing streamflow-gaging stations (discussed in the "Gain-Loss Streamflow Measurements" section).

\section{Water-Level-Altitude Measurements}

Using methods described by Cunningham and Schalk (2011), depth to groundwater was measured at as many as 33 different State wells in the upper Coleto Creek watershed with either a steel tape or an electronic water-level contact tape (e-line) three separate times: (1) August 4-7 and 12,
2009; (2) January 12-14 and 22, 2010; and (3) June 21-24, 2010. At some sites, water levels might not have been measured for one of the following reasons: the well was being pumped at the time of the site visit, the field technician was unable to obtain permission to access the well, or the well was not incorporated into the network until after the first round of sampling. The depth to groundwater data were used to generate potentiometric surface maps for each of the three rounds of data collection. Water-level altitudes (WLAs) were subsequently computed by subtracting depth to water at each sampling location from ground-surface elevation at that location; ground-surface elevations were obtained by intersecting well locations with land-surface altitudes derived from the USGS National Digital Elevation dataset (Gesch, 2007). These data were used in conjunction with WLAs (when available) from three wells, which are continuously monitored for WLAs by the Texas Commission on Environmental Quality (TCEQ). Data from the three TCEQ wells used for this report were entered into the NWIS database (U.S. Geological Survey, 2011). Of the three monitoring wells operated by TCEQ, two were deactivated by TCEQ after the first sampling event (State wells 79-05-505 and 79-15-604 were deactivated on October 18, 2009, and November 4, 2009, respectively), but the third (State well 79-13-224) was active throughout the course of the study. USGS station numbers corresponding to all State well numbers used in this report are listed in table 2.

\section{Water-Quality Sample Collection}

A total of 44 water-quality samples were collected at 21 sites over the course of the three sampling events (August 4-7, 2009, January 12-14, 2010, and June 21-24, 2010). However, all sites were not sampled for all chemical constituents during all three sampling events. Stable isotope samples for hydrogen and oxygen were collected at all 21 sites. Physical properties (dissolved oxygen, $\mathrm{pH}$, specific conductance, temperature, and turbidity) were measured onsite using a YSI handheld multiparameter meter at all sites except USGS station 08177400 Coleto Creek Reservoir near Victoria, Tex., (hereinafter the Coleto Creek Reservoir site). Waterquality samples collected from all surface-water sites (table 1), and from Audilet Spring and the groundwater sampling sites (with the exception of those collected from State well 79-23-205 and the Coleto Creek Reservoir site; table 2) were analyzed for dissolved solids, major ions, alkalinity, nutrients, trace elements, and the stable isotope of strontium. Samples collected from State well 79-23-205 and the Coleto Creek Reservoir site were analyzed for hydrogen and oxygen stable isotope analyses exclusively. Of the 19 sites analyzed for a full suite of constituents, 4 were surface-water sites (streams) and the remaining 15 were groundwater sites (wells).

The four stream sites selected for water-quality analyses (USGS stations 08176540 Yorktown Creek at County Road 452 near Yorktown, Tex., 08176590 Fifteenmile Creek below Eighteenmile Creek near Ander, Tex., 08176900 on Coleto 
Table 2. Description of groundwater and spring sites in the upper Coleto Creek watershed, southeast Texas, August 2009-June 2010.

[USGS, U.S. Geological Survey; x, measurement made]

\begin{tabular}{|c|c|c|c|c|c|c|c|c|c|c|}
\hline \multirow{2}{*}{$\begin{array}{c}\text { Site } \\
\text { identifier } \\
\text { (figs. 4, 6, } \\
\text { 12-15) }\end{array}$} & \multirow[b]{2}{*}{$\begin{array}{c}\text { USGS } \\
\text { station number }\end{array}$} & \multirow{2}{*}{$\begin{array}{l}\text { State } \\
\text { well } \\
\text { number }\end{array}$} & \multirow[b]{2}{*}{ Site type } & \multirow[b]{2}{*}{ County } & \multicolumn{3}{|c|}{ Water-level measurement } & \multicolumn{3}{|c|}{ Water-quality sampling } \\
\hline & & & & & $\begin{array}{l}\text { August } \\
2009\end{array}$ & $\begin{array}{c}\text { January } \\
2010\end{array}$ & $\begin{array}{l}\text { June } \\
2010\end{array}$ & $\begin{array}{c}\text { August } \\
2009\end{array}$ & $\begin{array}{c}\text { January } \\
2010\end{array}$ & $\begin{array}{l}\text { June } \\
2010\end{array}$ \\
\hline 17 & 285750097224001 & 79-05-303 & Groundwater & DeWitt & $\mathrm{x}$ & $\mathrm{x}$ & $\mathrm{x}$ & $\mathrm{x}$ & & \\
\hline 18 & 285752097224201 & 79-05-304 & Groundwater & DeWitt & & $\mathrm{x}$ & $\mathrm{x}$ & & & \\
\hline 19 & 285919097232301 & $79-05-305$ & Groundwater & DeWitt & & $\mathrm{x}$ & $\mathrm{x}$ & & & \\
\hline 21 & 285541097285301 & 79-05-407 & Groundwater & DeWitt & $\mathrm{x}$ & $\mathrm{x}$ & $\mathrm{x}$ & & & \\
\hline 22 & 285726097295301 & $79-05-406$ & Groundwater & DeWitt & $\mathrm{x}$ & $\mathrm{x}$ & $\mathrm{x}$ & & & \\
\hline 24 & 285658097290101 & 79-05-408 & Groundwater & De Witt & $\mathrm{x}$ & $\mathrm{x}$ & $\mathrm{x}$ & $\mathrm{x}$ & $\mathrm{x}$ & $\mathrm{x}$ \\
\hline 25 & 285543097252301 & 79-05-505 & Groundwater & De Witt & $\mathrm{x}$ & & & & & \\
\hline 28 & 285337097224301 & 79-05-903 & Groundwater & Goliad & $\mathrm{x}$ & $\mathrm{x}$ & $\mathrm{x}$ & & & \\
\hline 29 & 285344097224001 & 79-05-904 & Groundwater & Goliad & $\mathrm{x}$ & $\mathrm{x}$ & $\mathrm{x}$ & & & \\
\hline 33 & 285616097222801 & $79-06-411$ & Groundwater & DeWitt & $\mathrm{x}$ & $\mathrm{x}$ & $\mathrm{x}$ & $\mathrm{x}$ & $\mathrm{x}$ & $\mathrm{x}$ \\
\hline 36 & 285537097184201 & 79-06-506 & Groundwater & De Witt & $\mathrm{x}$ & $\mathrm{x}$ & $\mathrm{x}$ & & & \\
\hline 38 & 285345097222501 & $79-06-712$ & Groundwater & Goliad & $\mathrm{x}$ & $\mathrm{x}$ & $\mathrm{x}$ & & & \\
\hline 39 & 285459097201101 & 79-06-703 & Groundwater & DeWitt & $\mathrm{x}$ & $\mathrm{x}$ & $\mathrm{x}$ & & & \\
\hline 40 & 285434097191901 & 79-06-807 & Groundwater & DeWitt & $\mathrm{x}$ & $\mathrm{x}$ & $\mathrm{x}$ & & & \\
\hline 41 & 285445097215301 & 79-06-709 & Groundwater & DeWitt & $\mathrm{x}$ & $\mathrm{x}$ & $\mathrm{x}$ & $\mathrm{x}$ & & \\
\hline 42 & 285451097203401 & 79-06-710 & Groundwater & DeWitt & $\mathrm{x}$ & $\mathrm{x}$ & $\mathrm{x}$ & & & \\
\hline 43 & 285435097204301 & 79-06-707 & Groundwater & DeWitt & $\mathrm{x}$ & $\mathrm{x}$ & & & & \\
\hline 49 & 285443097174801 & 79-06-808 & Groundwater & DeWitt & $\mathrm{x}$ & $\mathrm{x}$ & $\mathrm{x}$ & $\mathrm{x}$ & $\mathrm{x}$ & $\mathrm{x}$ \\
\hline 50 & 285443097174802 & 79-06-809 & Groundwater & DeWitt & $\mathrm{x}$ & $\mathrm{x}$ & & & & \\
\hline 52 & 285254097195801 & $79-06-810$ & Groundwater & Goliad & $\mathrm{x}$ & $\mathrm{x}$ & $\mathrm{x}$ & $\mathrm{x}$ & & \\
\hline 56 & 285037097253901 & $79-13-231$ & Groundwater & Goliad & & $\mathrm{x}$ & $\mathrm{x}$ & & & \\
\hline 57 & 285038097255402 & $79-13-224$ & Groundwater & Goliad & $\mathrm{x}$ & & $\mathrm{x}$ & & & \\
\hline 58 & 285038097255401 & $79-13-225$ & Groundwater & Goliad & $\mathrm{x}$ & $\mathrm{x}$ & $\mathrm{x}$ & & & \\
\hline 71 & 285149097195201 & $79-14-204$ & Groundwater & Goliad & $\mathrm{x}$ & $\mathrm{x}$ & $\mathrm{x}$ & $\mathrm{x}$ & $\mathrm{x}$ & $\mathrm{x}$ \\
\hline 72 & 285129097195401 & $79-14-202$ & Groundwater & Goliad & $\mathrm{x}$ & $\mathrm{x}$ & $\mathrm{x}$ & & & \\
\hline 73 & 285025097182101 & $79-14-205$ & Groundwater & Goliad & $\mathrm{x}$ & $\mathrm{x}$ & $\mathrm{x}$ & $\mathrm{x}$ & $\mathrm{x}$ & $\mathrm{x}$ \\
\hline 74 & 285025097180201 & $79-14-203$ & Groundwater & Goliad & $\mathrm{x}$ & & $\mathrm{x}$ & & & \\
\hline 82 & 285203097163001 & 79-14-303 & Groundwater & Victoria & $\mathrm{x}$ & $\mathrm{x}$ & $\mathrm{x}$ & & & \\
\hline 85 & 284518097185401 & 79-14-804 & Groundwater & Goliad & $\mathrm{x}$ & $\mathrm{x}$ & $\mathrm{x}$ & $\mathrm{x}$ & $\mathrm{x}$ & $\mathrm{x}$ \\
\hline 91 & 285134097130601 & $79-15-101$ & Groundwater & Goliad & $\mathrm{x}$ & $\mathrm{x}$ & $\mathrm{x}$ & $\mathrm{x}$ & $\mathrm{x}$ & $\mathrm{x}$ \\
\hline 92 & 285116097124501 & $79-15-102$ & Groundwater & Goliad & $\mathrm{x}$ & $\mathrm{x}$ & $\mathrm{x}$ & & & \\
\hline 93 & 285216097112801 & $79-15-205$ & Groundwater & Victoria & $\mathrm{x}$ & $\mathrm{x}$ & $\mathrm{x}$ & $\mathrm{x}$ & & \\
\hline 94 & 285049097111201 & $79-15-206$ & Groundwater & Victoria & $\mathrm{x}$ & $\mathrm{x}$ & $\mathrm{x}$ & $\mathrm{x}$ & & \\
\hline 98 & 284801097081601 & $79-15-604$ & Groundwater & Victoria & $\mathrm{x}$ & & & & & \\
\hline 100 & 284535097095101 & 79-15-904 & Groundwater & Victoria & $\mathrm{x}$ & $\mathrm{x}$ & $\mathrm{x}$ & $\mathrm{x}$ & $\mathrm{x}$ & $\mathrm{x}$ \\
\hline 107 & 284240097112201 & $79-23-205$ & Groundwater & Victoria & & & & & $\mathrm{x}$ & \\
\hline 108 & 285345097215201 & 79-06-713 & Groundwater & DeWitt & & $\mathrm{x}$ & $\mathrm{x}$ & & $\mathrm{x}$ & $\mathrm{x}$ \\
\hline 45 & 285354097215401 & $\begin{array}{l}\text { 79-06-711 } \\
\text { (Audilet } \\
\text { Spring) }\end{array}$ & Spring & Goliad & & & & $\mathrm{x}$ & $\mathrm{x}$ & $\mathrm{x}$ \\
\hline
\end{tabular}


Creek, and 08177300 on Perdido Creek [table 1, fig. 4]) were not flowing when the sites were visited during August 2009, so five alternate sites (wells) were sampled in their place (State wells 79-15-206, 79-15-205, 79-06-810, 79-06-709, and 79-05-303, respectively). Because the streams were flowing past the four streamflow-gaging stations during the two subsequent sampling events, the five alternate sites were sampled only once (August 2009), and the four stream sites were sampled two times each (January 2010 and June 2010). Samples were collected only once (during January 2010) from the Coleto Creek Reservoir site and from State well 79-23-205, whereas State well 79-06-713 was sampled twice, in January 2010 and June 2010. The nine remaining sites (all wells) were each sampled during all three sampling events.

Water-quality samples were collected, processed, and preserved in accordance with standard USGS methods documented in the "National Field Manual for the Collection of Water-Quality Data" (U.S. Geological Survey, variously dated). In preparation for the collection of groundwater samples, all wells were pumped until the physical properties stabilized prior to sample collection and processing. Surfacewater sampling was also predicated on field-measurement stabilization prior to sample collection and processing. Physical properties were considered stable when the variation between five or more sequential field-measurement readings was less than 0.3 milligram per liter $(\mathrm{mg} / \mathrm{L})$ for dissolved oxygen, 5 percent for specific conductance, 0.05 unit for $\mathrm{pH}$, and 0.2 degrees Celsius for temperature. Groundwater and surface-water samples were collected at each site in a 2-liter Teflon bottle, which was then subsampled into the appropriate bottles for the desired analyses at the site in question.

\section{Analytical Methods}

Using the inflection point method, alkalinity was determined at the time of sample collection by titration of $50 \mathrm{~mL}$ of filtered sample with 1.6-normal sulfuric acid to a $\mathrm{pH}$ of less than 4.0 (Rounds, 2006). All samples had negligible hydroxide and carbonate concentrations, so these ions were not considered in this report. The water-quality samples were analyzed for major ions, nutrients, trace elements, and selected stable isotopes. Water samples were analyzed in accordance with approved methods by the USGS National Water Quality Laboratory (NWQL) in Denver, Colo., for major ions (Fishman and Friedman, 1989; Fishman, 1993), nutrients (Fishman, 1993; Patton and Truitt, 2000), and trace elements (Fishman and Friedman, 1989; Garbarino, 1999; and Garbarino and others, 2006).

Samples for stable isotopes of hydrogen and oxygen were analyzed by the USGS Stable Isotope Laboratory in Reston, Va. (Epstein and Mayeda, 1953; Coplen and others, 1991). Stable isotopes are reported as the ratio of the two most abundant isotopes of a given element. The most abundant isotopes of hydrogen are hydrogen- $2\left({ }^{2} \mathrm{H}\right)$, which is also referred to as deuterium (D), and hydrogen-1 $\left({ }^{1} \mathrm{H}\right)$, which is also referred to as protium. The most abundant isotopes of oxygen are oxygen-18 $\left({ }^{18} \mathrm{O}\right)$ and oxygen- $16\left({ }^{16} \mathrm{O}\right)($ Clark and Fritz, 1997). Water molecules with a larger percentage of the lighter hydrogen and oxygen isotopes $\left({ }^{1} \mathrm{H}\right.$ and ${ }^{16} \mathrm{O}$, respectively) evaporate preferentially compared to water molecules with a larger percentage of the heavier hydrogen and oxygen isotopes $\left({ }^{2} \mathrm{H}\right.$ and ${ }^{18} \mathrm{O}$, respectively) (Bruckner, 2009). Stable isotope analysis results for ${ }^{2 / 1} \mathrm{H}$ and ${ }^{18 / 16} \mathrm{O}$ are reported as $\delta \mathrm{D}$ and $\delta^{18} \mathrm{O}$, respectively, each of which represents the relative difference in parts per thousand (per mil) between the sample isotope ratio and the isotope ratio of a known standard (Kendall and McDonnell, 1998). The ratios of naturally occurring, stable isotopes of strontium (strontium-87/strontium-86, also notated $\delta^{87} \mathrm{Sr} / \delta^{86} \mathrm{Sr}$ ) were determined by the USGS National Research Program Laboratory in Menlo Park, Calif., in accordance with approved methods (Bayless and others, 2004).

\section{Quality Assurance}

Quality control (QC) samples were collected to ensure the quality, precision, accuracy, and completeness of the water-quality dataset. Water-quality samples were collected and processed by following the procedures documented in the USGS National Field Manual (U.S. Geological Survey, variously dated). One equipment blank was collected on August 10, 2009, and sequential-replicate samples were collected on August 5, 2009 (State well 79-06-411), and on January 11, 2010 (State well 79-14-804); these results are listed in appendix 1 . The equipment blank was analyzed for major ions, nutrients, and trace elements; replicate samples were analyzed for major ions, nutrients, trace elements, and stable isotopes $\left(\delta \mathrm{D}, \delta^{18} \mathrm{O}\right.$, and $\left.\delta^{87} \mathrm{Sr} / \delta^{86} \mathrm{Sr}\right)$.

As noted by Fleming and others (2011, p. 18), "the accuracy of major dissolved-constituent values in a reasonably complete chemical analysis of a water sample can be checked by calculating the cation-anion balance (Hem, 1985). If the analytical work has been performed accurately, and if all major ions were analyzed, the difference between the two sums will generally not exceed approximately plus or minus 5 percent." Additional quality-control checks of ionic balances revealed the analyses for some constituents were suspect for samples collected at two of the wells. The cationanion balance of samples collected August 6, 2009, at State well 79-15-101 exceeded the plus or minus 5 percent criterion (the cation concentrations were all markedly smaller compared to the anion concentrations, possibly because the deionized water used to rinse the filter had not been completely evacuated prior to filling the sample bottle) and the cation concentrations were judged erroneous by the authors. In addition, alkalinity for the sample collected at State well 79-15-904 on June 21, 2010, was judged erroneously low; there were no corroborating data (such relatively low concentrations of other anions or cations) to substantiate the validity of this alkalinity value. The cation data collected August 6, 2009, from State well 79-15-101 and alkalinity measured June 21, 2010, from 
State well 79-15-904 were not included in the report and will not be discussed further.

Total nitrogen (calculated as the sum of nitrate, nitrite, ammonia, and organic nitrogen) and two trace-metal constituents (cobalt and iron) were detected in the equipment blank collected on August 10, 2009. Cobalt was detected in the blank at a concentration of 0.08 microgram per liter $(\mu \mathrm{g} / \mathrm{L})$, which is relatively small compared to the cobalt concentrations in most environmental samples (less than 26 percent of the median concentration of $0.32 \mu \mathrm{g} / \mathrm{L}$ for all 31 groundwater environmental samples [excluding Audilet Spring]) collected during the study. Iron was detected in the blank at an estimated concentration of $2 \mu \mathrm{g} / \mathrm{L}$, which was less than iron concentrations in each of the 12 groundwater environmental samples in which iron was detected; iron was not detected (had a concentration less than the laboratory reporting level) in the remaining 19 groundwater environmental samples. The estimated concentration of total nitrogen in the blank was $0.07 \mathrm{mg} / \mathrm{L}$, which was less than 7 percent of the median total nitrogen concentration of $1.02 \mu \mathrm{g} / \mathrm{L}$ measured in the 26 groundwater samples with detected amounts of total nitrogen; total nitrogen was not detected in the four remaining groundwater environmental samples. Dissolved solids also were detected at a concentration of $10 \mathrm{mg} / \mathrm{L}$, which was less than 2 percent of the median dissolved solids concentration of $585 \mathrm{mg} / \mathrm{L}$ in the 31 groundwater environmental samples.

The two replicate samples were compared to their associated environmental samples by calculating the relative percent difference (RPD) for each pair of detected constituents (appendix 1). If one or both of the concentrations in a constituent pair were less than the long-term method detection level (LT-MDL) or were reported as estimated, the RPD was not calculated for that pair. Estimated concentrations fall between the laboratory reporting limit (LRL), which is twice the LT-MDL, and the LT-MDL. Concentrations less than the LT-MDL are reported as less than the LRL (Childress and others, 1999). RPDs also were not calculated for physical properties measured in the field or laboratory analysis of specific conductance and $\mathrm{pH}$. Of the 103 constituent pairs (52 from State well 79-06-411 on August 5, 2009, and 51 from State well 79-14-804 on January 11, 2010), the RPD was computed for 74 sequentialreplicate pairs of data (37 from State well 79-14-804 and 37 from State well 79-06-411) using the equation

$$
\mathrm{RPD}=\left|C_{1}-C_{2}\right| /\left(\left(C_{1}+C_{2}\right) / 2\right) \times 100
$$

where

$$
\begin{aligned}
& C_{1} \quad \begin{array}{l}
\text { is the concentration from environmental } \\
\text { sample and }
\end{array} \\
& C_{2} \quad \text { is the concentration from sequential-replicate } \\
& \text { sample. }
\end{aligned}
$$

RPDs less than 15 percent indicate good agreement between analytical results, assuming the concentrations are sufficiently large compared to the LRL. Using samples collected from State well 79-14-804, the RPD was computed for 37 pairs of analyses of physical properties or constituents (hereinafter data pairs). Of these 37 data pairs, the RPD was within 15 percent for 35 data pairs; the 2 data pairs that exceeded 15 percent were for cobalt ( 62 percent), and lead (35 percent). Of the 37 data pairs for which RPD was computed using samples collected from State well 79-06-411, the RPD was within 15 percent for 35 data pairs; the 2 data pairs that exceeded 15 percent were for noncarbonate hardness (36 percent) and cobalt (86 percent).

Water-level measurements were made in accordance with standard USGS procedures (U.S. Geological Survey, 1980). All water-level data were entered into the National Water Information System (NWIS) database and reviewed by USGS personnel following standard USGS procedures. A minimum of two measurements were made at each well. If the two initial measurements were within $0.01 \mathrm{ft}$ of each other, then no additional measurements were required. If the two measurements did not agree within a precision of about $0.02 \mathrm{ft}$, owing to recent pumpage, damp casing, or general difficulty in obtaining a good reading, measurements were repeated until the reason for the lack of agreement was determined or until the results were shown to be reliable. WLA measurements were made when the pumps in wells were idle; however, antecedent pumping conditions and the pumping status of adjacent wells were not always known.

Field logs were used to document proper equipment operation and maintenance, as well as representative sample-collection and measurement conditions. Site visits to streamflow-gaging stations were made routinely (about every 6 weeks) by USGS personnel to ensure that equipment was functioning properly; sites were also visited in the event of equipment malfunctions.

\section{Streamflow}

\section{Continuous Streamflow Data}

Streamflow hydrographs for June 1, 2009-June 30, 2010, were prepared for stations 08176900 on Coleto Creek and 08177300 on Perdido Creek in the study area (figs. $5 A$ and $5 B)$. Rainfall data recorded at the National Weather Service (NWS) meteorological station 411880 Coleto Creek Reservoir (fig. 1, table 3) are shown (fig. 5C). Data from NWS 419361 Victoria Fire Department Station 5 (approximately $18 \mathrm{mi}$ northeast of NWS station 411880) were used to fill in missing record on April 25, 2010, and June 10, 2010. There appears to be a relation between the observed rainfall at NWS station 411880 and the measured streamflow at stations 08176900 on Coleto Creek and 08177300 on Perdido Creek (fig. 5). Exceptional drought conditions (U.S. Drought Monitor, 2011) persisted in the study area during summer 2009; from June 1 through August 12, 2009, only 0.89 inch (in.) of precipitation was recorded at NWS station 411880 (National Climatic Data Center, 2011). As a result, there was no flow past the USGS streamflow-gaging stations on Coleto or Perdido Creek 

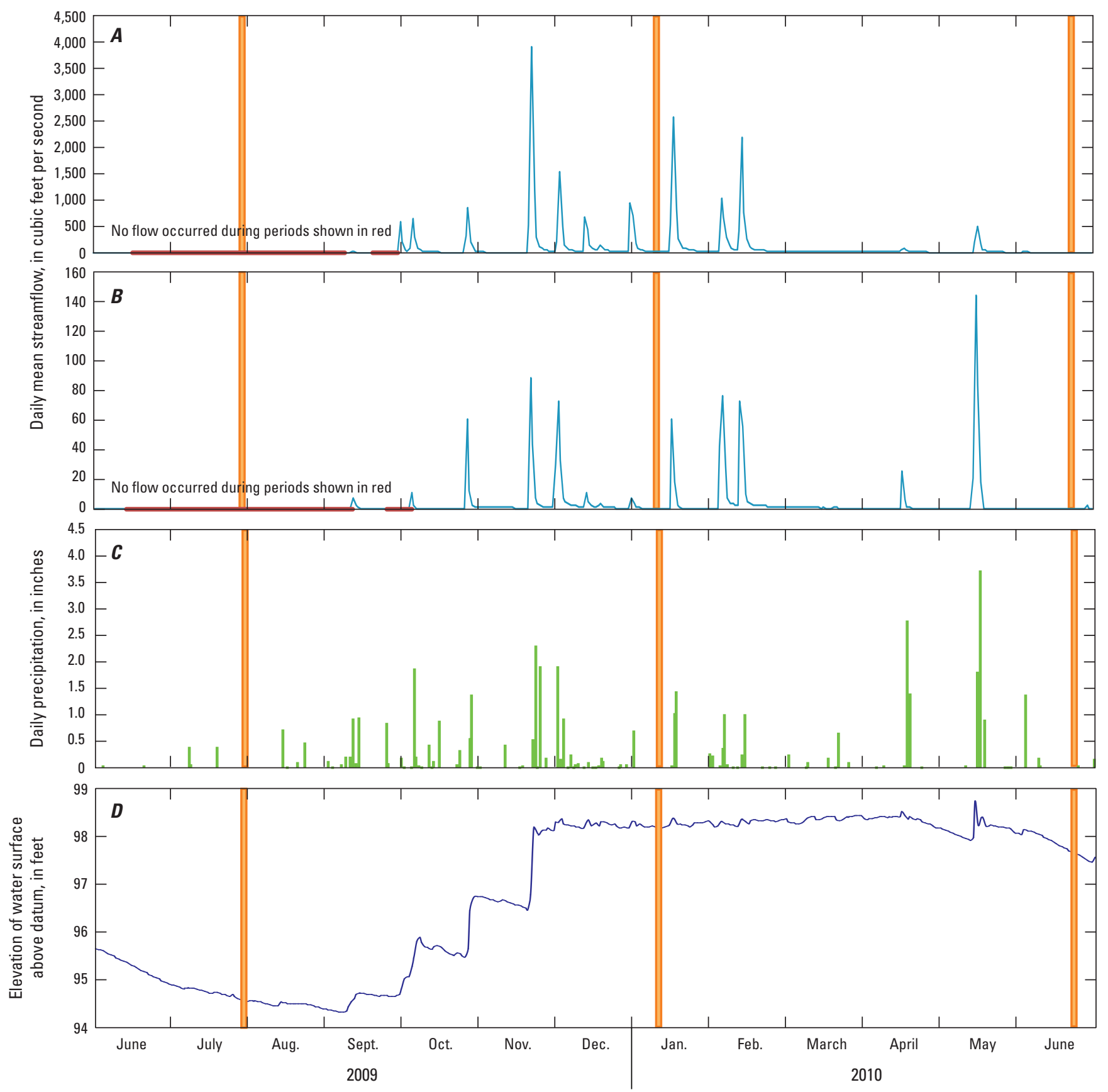

EXPLANATION

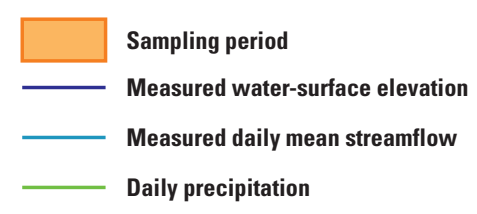

Figure 5. Measured daily mean streamflow at U.S. Geological Survey (USGS) streamflow-gaging stations $A, 08176900$ Coleto Creek at Arnold Road Crossing near Schroeder, Texas, and B, 08177300 Perdido Creek at Farm Road 622 near Fannin, Texas; C, Precipitation data measured at National Weather Service meteorological station 411880 Coleto Creek Reservoir (National Climatic Data Center, 2011); and D, Measured water-surface elevations at USGS station 08177400 Coleto Creek Reservoir near Victoria, Texas, June 1, 2009-June 30, 2010. 
Table 3. Rainfall data obtained from National Weather Service meteorological stations in and near the upper Coleto Creek watershed, southeast Texas, during June 1, 2009-August 12, 2009.

[NWS, National Weather Service; DMS, degrees, minutes, seconds; --, not available]

\begin{tabular}{|c|c|c|c|c|c|c|}
\hline $\begin{array}{l}\text { NWS site } \\
\text { identifier } \\
\text { (fig. 2) }\end{array}$ & Station number and name & $\begin{array}{l}\text { Latitude } \\
\text { (DMS) }\end{array}$ & $\begin{array}{l}\text { Longitude } \\
\text { (DMS) }\end{array}$ & $\begin{array}{l}\text { Type of } \\
\text { data }\end{array}$ & Period of record used & $\begin{array}{c}\text { Amount of } \\
\text { rainfall, } \\
\text { in inches }\end{array}$ \\
\hline 1 & NWS 411880 Coleto Creek Reservoir & $28^{\circ} 43^{\prime}--^{\prime \prime}$ & $97^{\circ} 10^{\prime}--^{\prime \prime}$ & Rainfall & $\begin{array}{c}\text { June } 1,2009, \text { through } \\
\text { August 12, } 2009\end{array}$ & 0.89 \\
\hline 2 & NWS 419361 Victoria Fire Department Station $5^{1}$ & $28^{\circ} 52^{\prime}--^{\prime \prime}$ & $97^{\circ} 01^{\prime}--^{\prime \prime}$ & Rainfall & $\begin{array}{l}\text { April } 25,2010 \text {, and } \\
\text { June } 19,2010\end{array}$ & $\begin{array}{c}0.00 \\
\text { (both days) }\end{array}$ \\
\hline
\end{tabular}

${ }^{1}$ Used to fill in missing record at NWS 411880.

(stations 08176900 on Coleto Creek and 08177300 on Perdido Creek) during most of the summer of 2009 (figs. $5 A$ and $5 B$ ); there also was no flow past the streamflow-gaging stations on Coleto or Perdido Creek during parts of September and October 2009. Rainfall events and resulting increases in streamflow were more frequent from early October 2009 through February 2010. Figure 5 also shows when streamflow measurement surveys were made ("Sampling periods"). During the three measurement surveys (July 29, 2009, January 11, 2010, and June 21,2010), instantaneous streamflows at the station 08176900 on Coleto Creek were zero, 24.6, and 5.85 cubic feet per second $\left(\mathrm{ft}^{3} / \mathrm{s}\right)$, respectively; daily mean streamflows measured at the adjacent gaging station on those same three days were zero, 27 , and $5.4 \mathrm{ft}^{3} / \mathrm{s}$, respectively. Instantaneous streamflows at station 08177300 on Perdido Creek were zero, 0.23 , and $0.04 \mathrm{ft}^{3} / \mathrm{s}$, respectively; daily mean streamflows measured at the adjacent gaging station on those same three days were zero, 0.23 , and $0.04 \mathrm{ft}^{3} / \mathrm{s}$, respectively.

Water-surface elevation data measured at the Coleto Creek Reservoir site from June 1, 2009, through June 30, 2010 , are plotted on figure $5 D$, along with daily precipitation data measured at the NWS meteorological weather 411880 on figure $5 C$. The stage of Coleto Creek Reservoir is regulated by GBRA and is $98 \mathrm{ft}$ when the reservoir is at normal capacity. The general expression of reservoir stage depicts a gradual decrease in stage from $95.65 \mathrm{ft}$ on June 1, 2009, to $94.33 \mathrm{ft}$ on September 6, 2009, after several months of below-average precipitation in the region; minimal inflows from contributing streams were likely received by Coleto Creek Reservoir during this period based on continuously monitored streamflow data collected at stations 08176900 and 08177300 on Coleto and Perdido Creeks, respectively, as well as data collected during the gain-loss survey during July 29-30, 2009. Evaporative effects associated with the summer months also contributed to the reduction in stage during this period. After precipitation events on September 6-9, 2009 (3.86 in.), October 3-4, 2009 (2.28 in.), October 26, 2009 (1.84 in.), and November 20, 2009 (2.85 in.), abrupt increases, in stairstep fashion, raised the overall reservoir stage to the 98.0 - to 98.5 -ft range, where it remained from late November until mid-April; releases from the reservoir were made by GBRA during this period to maintain normal reservoir capacity. From mid-April to the end of June 2010, gradual decreases in reservoir stage, likely associated with evaporative effects, were observed. A large precipitation event on May 14-15, 2010 (5.08 in.), resulted in the peak stage of $98.75 \mathrm{ft}$ for the period shown. Precipitation from large storms tends to be variable, with the largest amounts falling in localized areas. This likely explains why certain precipitation events (1.76 in. on September 22, 2009) did not elicit comparable responses in reservoir stage relative to other events of similar magnitude (1.84 in. on October 26, 2009). Virtually no change in reservoir stage was observed after the precipitation event on September 22, whereas an increase in reservoir stage of $0.8 \mathrm{ft}$ was observed after the October 26 event. Additionally, no change in flow was observed at station 08176900 on Coleto Creek after the precipitation event on September 22 (fig. $5 A$ ), which indicates that this event likely occurred downstream from station 08176900 . Peaks in daily mean streamflow at station 08176900 on Coleto Creek from December 2009 through February 2010 did correspond to peaks in reservoir stage measured at the Coleto Creek Reservoir site, indicating releases likely were being made from Coleto Creek Reservoir to control reservoir stage during this period. Abrupt increases in reservoir stage from June to November 2009 were also observed in measured daily mean streamflow at station 08176900 on Coleto Creek. Changes in reservoir stage caused by releases from Coleto Creek Reservoir are unknown and were not considered in the evaluation of Coleto Creek Reservoir stage.

\section{Gain-Loss Streamflow Measurements}

Groundwater inflow to streams and stream outflow to groundwater are typically not measured directly because these processes usually cannot be observed; even visible inflow from springs cannot always be measured accurately (Ockerman, 2002). As a result, inflow from or outflow to groundwater in stream reaches within the study area were estimated by measuring the difference in streamflow at the upstream and downstream ends of the reaches (fig. 6). Groundwater inflow 
and outflow are not exclusive sources of gain or loss to the streams; other sources might include tributary inflow, stream diversions and return flows, spring inflow, and evaporative losses. Groundwater flux, $G$, is estimated as

$$
G=Q_{D}-Q_{U}-I+D-R-S+E
$$

where

$\begin{array}{cl}Q_{D} \quad \begin{array}{l}\text { is measured streamflow at the downstream } \\ \text { boundary of the reach, }\end{array} \\ Q_{U} \quad \begin{array}{l}\text { is measured streamflow at the upstream } \\ \text { boundary of the reach, }\end{array} \\ I \quad \begin{array}{l}\text { is measured or estimated inflows from } \\ \text { tributaries, }\end{array} \\ D \quad \text { is diversions from the reach, } \\ R & \text { is return flows to the reach, } \\ S & \text { is spring contributions, and } \\ E & \text { is estimated evaporation losses. }\end{array}$

A positive value for $G$ is indicative of a gaining stream reach, whereas a negative value for $G$ is indicative of a losing stream reach. Tributary inflows $(I)$ do exist within the study area, but the way in which the affected reaches $(\mathrm{C} 4, \mathrm{C} 6, \mathrm{C} 11$, $\mathrm{C} 15$, and $\mathrm{C} 19$; fig. 6) were established incorporates these contributions automatically into the measured streamflow at the upstream boundary of the reach. Tributaries other than those that contribute to reaches $\mathrm{C} 4, \mathrm{C} 6, \mathrm{C} 11, \mathrm{C} 15$, and $\mathrm{C} 19$ were ignored because they were assumed to be dry during the three gain-loss surveys. As a result, tributary inflow provides no additional contribution to streamflow. No diversions $(D)$ from reaches in the upper Coleto Creek watershed are known, nor are there any known return flows $(R)$ to the reaches in the upper Coleto Creek watershed, so these contributions were excluded from groundwater flux calculations.

Spring contributions $(S)$ to streamflow were not measured at any of the known springs in the study area. As a result, spring contributions could not be included as a separate source in the groundwater flux calculations. Rather, spring contributions were part of the measured streamflow at the downstream boundaries of each reach that a spring (or springs) contributed to. Discharge from Audilet Spring was observed during all three sampling events but was never measured directly. However, the streamflow contribution associated with Audilet Spring is likely substantial relative to the magnitude of flows observed in individual stream reaches over the upper Coleto Creek watershed as a whole. The greatest difference in measured streamflow in January 2010 within a single reach $\left(10.37 \mathrm{ft}^{3} / \mathrm{s}\right)$ occurred in reach $\mathrm{C} 9$, which receives contributions from Audilet Spring; this value is more than 2.5 times the second highest difference in measured streamflow within a reach from that same time period $\left(4.02 \mathrm{ft}^{3} / \mathrm{s}\right.$ at reach $\left.\mathrm{C} 15\right)$. In addition, the only reaches in the study area with measurable streamflow in July 2009 were reaches C9 and C10 (the reach immediately downstream from reach (9). By eliminating these four terms $(I, D, R$, and $S$ ) from the equation above, equation 2 for $G$ reduces to

$$
G=Q_{D}-Q_{U}+E
$$

Evaporation within each reach was estimated by using pan evaporation data from the Texas Water Development Board Center for Research in Water Resources (2010) for a station in Cheapside, Tex. (about 16 mi northwest of Cuero, Tex.). Monthly evaporation data from a 52-month period (starting on August 1, 2003, and ending on December 1, 2007) were used to calculate average daily pan evaporation rates for each of the three sampling periods. These rates were then applied to the surface area of each reach to estimate evaporative losses. Using the stream widths measured prior to the collection of discharge data, the surface area of each reach was calculated by multiplying the average of the widths at the upstream and downstream ends of the reach by reach length.

Five of the stream reaches in the study area $(\mathrm{C} 4, \mathrm{C} 6$, $\mathrm{C} 11, \mathrm{C} 15$, and C19) include a confluence of two streams, which means there are two upstream ends to each of these five reaches. In these five cases, the average stream width used in the reach surface-area component of the evaporative loss calculation was calculated as a weighted proportion of upstream and downstream widths and stream-segment lengths. Data used in the calculation of evaporative loss estimates are given in appendix 2.

During periods when flow was common (such as June 2010, with 12 of 25 reaches flowing) or likely (such as January 2010, with 22 of 25 reaches flowing) the majority of the reaches were gaining, which means that the aquifer was discharging water to the stream reaches. During January 2010, 19 of the 22 reaches with streamflow were gaining (about 86 percent), and during June 2010, 11 of the 12 reaches with streamflow were gaining (about 92 percent). However, during drought-like conditions (July 2009), there was virtually no streamflow in the entire upper Coleto Creek watershed. The only streamflow observed was in reach C9 (fig. 6), which receives inflow from Audilet Spring, and reach C10 (fig. 6), which is the next downstream reach from C9. Water levels in the aquifer at this time seemed to have been reduced to the point that quantities of water discharged to the streams were insufficient to sustain flow.

In two cases, reaches had to be grouped together for gainloss calculations because a streamflow measurement was not made at the site that acts as the dividing point between the two reaches in question. This occurred in July 2009, when reaches $\mathrm{C} 11$ and $\mathrm{C} 14$ had to be combined because streamflow was not measured at USGS station 08176590 Fifteenmile Creek below Eighteenmile Creek site (site 80 in figs. 4 and 6). There was no way to calculate gains or losses in the two stream reaches individually because this site acts as the downstream boundary of reach $\mathrm{C} 11$ and the upstream boundary of reach $\mathrm{C} 14$. The same is true of reaches C14 and C15 in June 2010, when streamflow was not measured at station 08176592 Fifteenmile Creek near Ander, Tex. (site 79; figs. 4 and 6).

For this report, a stream reach is classified as verifiably gaining or losing only if the difference in streamflow between the upstream and downstream measuring sites exceeds the 
potential error associated with the flow measurements made at those locations. Measurement error is a function of the streamflow measurement rating (excellent, good, fair, or poor) as determined by the hydrographer (streamgager) (Sauer and Meyer, 1992). The rating is based on streambed conditions, velocity homogeneity, cross-section uniformity, and any additional factors that affect the measurement accuracy. Measurements rated as excellent are believed to be within 2 percent of the actual flow, good are believed to be within 5 percent of flow, fair are believed to be within 8 percent of flow, and poor are believed to differ from actual flow by greater than 8 percent (set at 10 percent for the purposes of error calculations in this report). In the event that a measurement rating was unspecified, a measurement rating of "poor" was applied. The potential errors associated with the one to three streamflow measurements used to calculate gain-loss measurements for each reach were summed to obtain the potential composite error for comparison with the computed gain or loss. Most of the reported streamflows in this study (table 4) were an average of two measurements, each made by a different hydrographer. For three cases (at USGS station 08176580 Eighteenmile Creek at Highway 77A/183 near Ander, Tex., on June 22, 2010, station 08177300 on Perdido Creek on June 21, 2010, and at USGS station 08177270 Turkey Creek at Farm

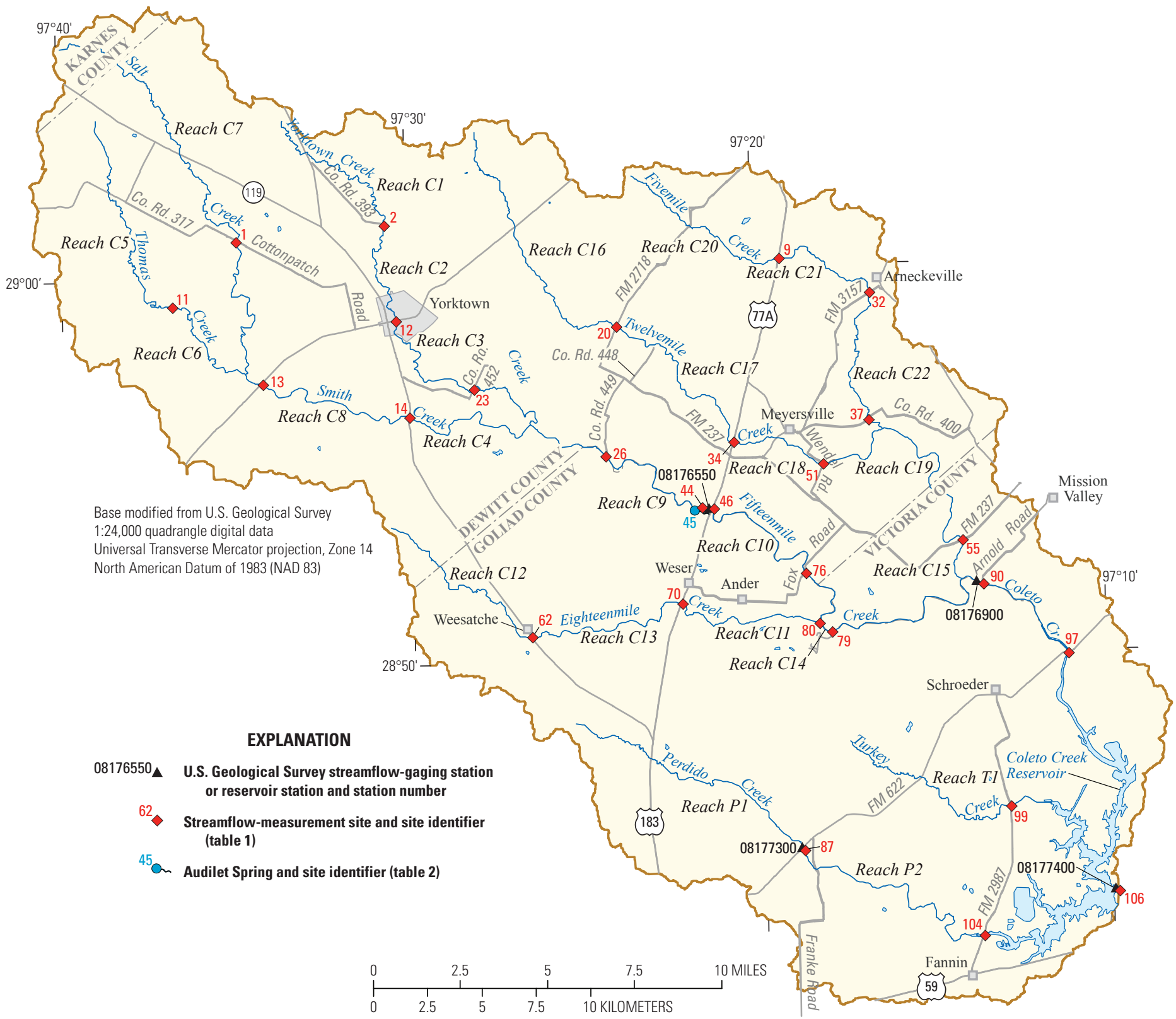

Figure 6. Location of stream reaches, U.S. Geological Survey streamflow-measurement sites, streamflow-gaging stations, reservoirstage gaging station, inflows, and spring in the upper Coleto Creek watershed, southeast Texas. 
Road 2987 near Fannin, Tex., on January 11, 2010), only one measurement could be made, so the value shown has been qualified as an estimate. In one case (USGS station 08176550 Fifteenmile Creek near Weser, Tex., on July 29, 2009), the reported streamflow was an average of four measurements. In some cases, the measurement rating differed between the two consecutively collected measurements at a site. In these instances, an average of the potential errors associated with each of the streamflow measurements was applied to the average of the two streamflow measurements for that location in the potential composite error calculations. None of the streamflow measurements from this study were classified as good or excellent. A summary of gain-loss determinations for reaches along Coleto Creek and contributing streams during each of the three streamflow-measurement surveys is given in table 5 .

\section{Groundwater Hydrology}

Potentiometric-surface maps (maps of water-levelaltitude contours) were generated for each of three sampling periods (August 2009, fig. 7; January 2010, fig. 8; and June 2010, fig. 9) to help characterize the groundwater hydrology of the Evangeline aquifer in the study area. For each of the potentiometric-surface maps, there were one or two waterlevel-altitude measurements that were not used because they differed markedly from surrounding water-level altitudes and groundwater-level-altitude contours, possibly because the well had been recently pumped; these values are designated on figs. 7-9. In general, the groundwater flow direction is toward the southeast in the upper part of the study area (west of U.S. Highway 77A) and toward the east in the lower part of the study area (east of U.S. Highway 77A), roughly coinciding with the general flow direction of the main stem of Coleto Creek (figs. 7-9). Surface-water elevations from the streams in the study area were not included in the contouring process. The number of sites with continuous streamflow data (USGS streamflow-gaging station 08176550 Fifteenmile Creek near Weser, Tex., station 08176900 on Coleto Creek, and station 08177300 on Perdido Creek) is insufficient to provide an accurate graphical representation of the expected potentiometricsurface response with respect to the streams in the study area, particularly at the scale that these maps are presented.

The potentiometric-surface contours exhibit relatively consistent spacing patterns temporally from one sampling interval to the next (figs. 7-9), but some shifting of the potentiometric-surface between contours (to the southeast) did occur between each sampling event. This shift is especially apparent in figure 10, where potentiometric-surface contours from all three sampling events are overlain; in generating this figure, every other contour was removed from figures 7-9 to enhance interpretability. The most substantial shift occurred between August 2009 and January 2010, coincident with consistent precipitation from September 2009 through December 2009 (fig. 5C) after drought conditions during summer 2009 (fig. 10). The magnitude of the shift between January 2010 and
June 2010 was much smaller after inconsistent precipitation between January 2010 and May 2010 (fig. 5C). On the basis of data collected during these three sampling events, it appears that the Evangeline aquifer in the study area might be responding relatively quickly (within 3 months or less) to both the absence of precipitation (August 2009) and relative abundance of precipitation (January 2010). However, a network of wells continuously monitored for water levels on a long-term basis across the study area would be necessary to confirm this relation between changes in groundwater altitudes and rainfall.

Only 0.89 in. of precipitation was recorded at the NWS weather station at Coleto Creek Reservoir (fig. $5 C$; table 3) between June 1, 2009, and August 12, 2009, when the measurement of groundwater-level altitudes (WLAs) was completed. As a result, WLAs increased across the study area between the first (August 2009) and third (June 2010) sampling events (table 6); in wells where WLAs were measured during all three sampling events, WLAs increased $2.35 \mathrm{ft}$ on average during this period, and only one of the wells exhibited a decrease in WLA (State well 79-15-206). Most of the rebound in WLAs (1.71 ft, on average) was observed between the first and second (January 2010) sampling events. Only a 0.64 -in. increase in WLAs was observed, on average, between the second and third sampling events.

Each of the three potentiometric-surface maps (figs. 7, 8, and 9) shows mounding of groundwater around one or more wells. Mounding occurs around State well 79-06-703 in all three of the figures and around State well 79-15-206 in both August 2009 and June 2010. A small groundwater mound also occurs around State well 79-05-904 in August 2009. One possible reason for these patterns would be perched zones within the aquifer.

A perched aquifer zone might also be responsible for the highly elevated WLAs at State wells 79-13-231 (January 2010 and June 2010) and 79-13-224 (August 2009 and June 2010) relative to the WLAs measured at State well 79-13-225 during the same sampling events (table 6). The WLA at State well 79-13-224 was $28.86 \mathrm{ft}$ higher than the WLA at State well 79-13-225 in August 2009; the WLA at State well 79-13-231 was $39.95 \mathrm{ft}$ higher than the WLA at State well 79-13-225 in January 2010; and the WLAs at State wells 79-13-231 and 79-13-224 were 40.53 and $40.16 \mathrm{ft}$ higher than the WLA at State well 79-13-225 in June 2010, respectively. This is despite the fact that State wells 79-13-224 and 79-13-225 are only about $20 \mathrm{ft}$ from one another and State well 79-13-231 is about $0.25 \mathrm{mi}$ away from State well 79-13-225 over relatively flat terrain. WLAs from State wells 79-13-231 and 79-13-224 were not used during the potentiometric surface contouring process because of the large disparities between these two wells and State well 79-13-225. WLAs measured at State well 79-13-225 seemed to be more compatible with WLAs measured across the remainder of the study area, so this is the only one of the three wells used in the potentiometric-surface contouring process. An alternative explanation for the elevated WLAs measured at State wells 79-13-231 and 79-13-224 might be that these wells are partially or completely screened 
across an alluvial aquifer above the Evangeline aquifer. This scenario seems particularly plausible at State well 79-13-231, which is a hand-dug well.

\section{Water Quality}

During the three synoptic sampling events, a total of 44 water-quality samples ( 9 surface-water samples, 32 groundwater samples, and 3 spring samples) were collected and analyzed in most cases for selected physical properties (specific conductance, $\mathrm{pH}$, water temperature, dissolved oxygen, and alkalinity) and constituents (dissolved solids, major ions, nutrients, trace elements, and stable isotopes of hydrogen and oxygen, and strontium). Physical properties were not collected at the Coleto Creek Reservoir site, and the only constituents analyzed in samples collected from the Coleto Creek Reservoir site and State well 79-23-205 were stable isotopes of hydrogen and oxygen. Analytical results for all of the waterquality samples are listed in table 7.

\section{Dissolved Solids and Major-Ion Chemistry}

Dissolved solids concentrations were greater than the (U.S. Environmental Protection Agency (USEPA) Secondary Maximum Contaminant Level (SMCL) for drinking water of $500 \mathrm{mg} / \mathrm{L}$ in 74 percent of the samples that were analyzed for dissolved solids (U.S. Environmental Protection Agency, 2000). Water samples were relatively consistent in major-ion composition and largely reflect the mineral composition of the rock and sediment that make up the aquifer. Trilinear diagrams (fig. 11) show that the predominant cation is calcium, and bicarbonate constitutes the major anion. Chloride tends to be present in higher equivalent concentrations in spring and surface-water samples than in groundwater samples.

Dissolved solids concentrations are an important indicator of the suitability of water for human consumption, agriculture, and industrial use. Drinking water containing dissolved solids in excess of the USEPA SMCL is aesthetically undesirable but might be an adequate option in areas where less mineralized water is unavailable. Measured dissolved solids concentrations from the wells ranged from 435 to $871 \mathrm{mg} / \mathrm{L}$ (table 7); the median dissolved solids concentration among 31 well samples was $585 \mathrm{mg} / \mathrm{L}$, and 22 had concentrations greater than $500 \mathrm{mg} / \mathrm{L}$.

Chloride concentrations in excess of $250 \mathrm{mg} / \mathrm{L}$ (the USEPA SMCL) can impart an objectionable, salty taste in drinking water and accelerate the corrosion of metal pipes (U.S. Environmental Protection Agency, 2000). Chloride concentrations ranged from 34.1 to $271 \mathrm{mg} / \mathrm{L}$ among the samples collected at wells, and the median concentration among these 31 samples was $123 \mathrm{mg} / \mathrm{L}$. All three samples that exceeded
$250 \mathrm{mg} / \mathrm{L}$ were collected at State well 79-05-408. The source or sources of elevated chloride concentrations at this location are unknown; however, possible anthropogenic sources might include inorganic fertilizers, septic-tank effluent, animal feed, or irrigation drainage (World Health Organization, 2011). Chloride might also be leaching from soil or rock into the groundwater in this area.

Stiff diagrams (Stiff, 1951) were constructed by using major-ion data to depict temporal changes in water composition at a given site (fig. 12). At all four surface-water sampling locations, calcium, magnesium, and chloride concentrations were higher in January 2010 than in June 2010. Bicarbonate concentrations also were higher at three of the four surfacewater sites (samples collected at station 08177300 on Perdido Creek were the exception) in January 2010 compared to June 2010. Calcium concentrations in groundwater samples tended to be slightly lower in January 2010 than they were in the August 2009 and June 2010 sampling events. However, these variations are likely too small to be within the range of reproducibility for the laboratory analyses. The fact that all of the calcium concentrations were lower without a corresponding decrease in anion concentrations indicates this pattern might be a result of laboratory bias.

Stiff diagrams were also used as an alternative method for comparing water compositions spatially between different sites. Calcium, bicarbonate, and in some cases chloride were the predominant major ions (fig. 12, table 7). Major-ion compositions were relatively consistent among most of the samples, which can be characterized as generally calcium bicarbonate waters, with chloride often making a major contribution. The principal differences between diagrams from different sites were the magnitude of the calcium and bicarbonate contributions and the contribution of chloride relative to the other major-ion contributions. Chloride contributions to water composition seemed to be most prevalent in the samples collected either from streams or from wells close to the main stem of Coleto Creek. All State wells farther from the main stem of Coleto Creek, such as 79-05-303, 79-06-808, 79-14-204, 79-14-804, and 79-15-904, tended to have a smaller relative contribution of chloride to the major-ion composition. The Stiff diagrams for Audilet Spring and State well 79-06-713 have similar shapes, but the Audilet Spring diagram appears different relative to the State well 79-06-713 diagram. This means that the major ionic constituents that are used to construct Stiff diagrams were present in roughly the same proportions but at higher concentrations in Audilet Spring. This finding indicates that water from both sites might be derived from the same source but that the groundwater at State well 79-06-713 is likely (at least in part) from a different source. The other source is most likely recharge from precipitation, which tends to have relatively low concentrations of major ions compared to surface water or groundwater and would therefore serve to dilute the overall major-ion concentrations. 
Table 4. Summary of streamflow-measurement results, measurement error ratings, and potential measurement errors for reaches along Coleto Creek and contributing streams during streamflow-measurement surveys in July 2009, January 2010, and June 2010, upper Coleto Creek watershed, southeast Texas.

[USGS, U.S. Geological Survey; $\mathrm{ft}^{3} / \mathrm{s}$, cubic feet per second. Error ratings: F, fair; P, poor; U, unspecified; --, no data]

\begin{tabular}{|c|c|c|c|c|c|c|c|c|c|c|c|}
\hline $\begin{array}{c}\text { Site } \\
\text { identifier } \\
\text { (figs. 4, 6, } \\
\text { 12-15) }\end{array}$ & $\begin{array}{c}\text { USGS } \\
\text { station } \\
\text { number }\end{array}$ & Site name & $\begin{array}{l}\text { 1st gain- } \\
\text { loss survey, } \\
\text { July 29-30, } \\
2009\left(\mathrm{ft}^{3} / \mathrm{s}\right)\end{array}$ & $\begin{array}{l}\text { 1st gain- } \\
\text { loss survey } \\
\text { measure- } \\
\text { ment error } \\
\text { rating }\end{array}$ & $\begin{array}{c}\text { 1st gain- } \\
\text { loss survey } \\
\text { potential } \\
\text { measure- } \\
\text { ment error } \\
\left(\mathrm{ft}^{3} / \mathrm{s}\right)\end{array}$ & $\begin{array}{c}\text { 2nd gain- } \\
\text { loss survey, } \\
\text { January 11-13, } \\
2010\left(\mathrm{ft}^{3} / \mathrm{s}\right)\end{array}$ & $\begin{array}{l}\text { 2nd gain- } \\
\text { loss survey } \\
\text { measure- } \\
\text { ment error } \\
\text { rating }\end{array}$ & $\begin{array}{c}\text { 2nd gain- } \\
\text { loss survey } \\
\text { potential } \\
\text { measure- } \\
\text { ment error } \\
\left(\mathrm{ft}^{3} / \mathrm{s}\right)\end{array}$ & $\begin{array}{c}\text { 3rd gain- } \\
\text { loss survey, } \\
\text { June 21-22, } \\
2010 \\
\left(\mathrm{ft}^{3} / \mathrm{s}\right)\end{array}$ & $\begin{array}{l}\text { 3rd gain- } \\
\text { loss survey } \\
\text { measure- } \\
\text { ment error } \\
\text { rating }\end{array}$ & $\begin{array}{l}\text { 3rd gain- } \\
\text { loss survey } \\
\text { potential } \\
\text { measure- } \\
\text { ment error } \\
\left(\mathrm{ft}^{3} / \mathrm{s}\right)\end{array}$ \\
\hline 1 & 08176523 & $\begin{array}{l}\text { Salt Creek at County Road } 317 \\
\text { near Yorktown, Tex. }\end{array}$ & No flow & -- & -- & $0.14^{\mathrm{a}}$ & $\mathrm{P} / \mathrm{P}$ & 0.014 & No flow & -- & -- \\
\hline 2 & 08176535 & $\begin{array}{l}\text { Yorktown Creek at County Road } \\
393 \text { near Yorktown, Tex. }\end{array}$ & No flow & -- & -- & No flow & -- & -- & No flow & -- & -- \\
\hline 9 & 08176599 & $\begin{array}{l}\text { Fivemile Creek at Highway } \\
77 \mathrm{~A} / 183 \text { near Arneckville, Tex. }\end{array}$ & No flow & -- & -- & No flow & -- & -- & No flow & -- & -- \\
\hline 11 & 08176526 & $\begin{array}{l}\text { Thomas Creek at Cottonpatch } \\
\text { Road near Yorktown, Tex. }\end{array}$ & No flow & -- & -- & $.07^{\mathrm{a}}$ & $\mathrm{P} / \mathrm{P}$ & .007 & No flow & -- & -- \\
\hline 12 & 08176538 & $\begin{array}{l}\text { Yorktown Creek at Highway } 72 \text { at } \\
\text { Yorktown, Tex. }\end{array}$ & No flow & -- & -- & $.72^{\mathrm{a}}$ & $\mathrm{P} / \mathrm{P}$ & .072 & $0.30^{\mathrm{a}}$ & $\mathrm{P} / \mathrm{P}$ & 0.03 \\
\hline 13 & 08176529 & $\begin{array}{l}\text { Smith Creek at Highway } 72 \text { near } \\
\text { Yorktown, Tex. }\end{array}$ & No flow & -- & -- & $.46^{\mathrm{a}}$ & $\mathrm{F} / \mathrm{P}$ & .041 & No flow & -- & -- \\
\hline 14 & 08176532 & $\begin{array}{l}\text { Smith Creek at Highway } 119 \text { near } \\
\text { Yorktown, Tex. }\end{array}$ & No flow & -- & -- & $2.21^{\mathrm{a}}$ & $\mathrm{F} / \mathrm{F}$ & .177 & $1.28^{\mathrm{a}}$ & $\mathrm{P} / \mathrm{P}$ & .0128 \\
\hline 20 & 08176594 & $\begin{array}{l}\text { Twelvemile Creek at Farm Road } \\
2718 \text { near Yorktown, Tex. }\end{array}$ & No flow & -- & -- & $.27^{\mathrm{a}}$ & $\mathrm{F} / \mathrm{P}$ & .024 & No flow & -- & -- \\
\hline 23 & 08176540 & $\begin{array}{l}\text { Yorktown Creek at County Road } \\
452 \text { near Yorktown, Tex. }\end{array}$ & No flow & -- & -- & $2.16^{\mathrm{a}}$ & $\mathrm{P} / \mathrm{F}$ & .194 & $.83^{\mathrm{a}}$ & $\mathrm{P} / \mathrm{P}$ & .083 \\
\hline 26 & 08176544 & $\begin{array}{l}\text { Fifteenmile Creek at County Road } \\
449 \text { Road near Ander, Tex. }\end{array}$ & No flow & -- & -- & $.23^{\mathrm{a}}$ & $\mathrm{P} / \mathrm{P}$ & .023 & $2.89^{\mathrm{a}}$ & $\mathrm{P} / \mathrm{P}$ & .289 \\
\hline 32 & 08176675 & $\begin{array}{l}\text { Fivemile Creek at Farm Road } \\
3157 \text { near Arneckville, Tex. }\end{array}$ & No flow & -- & -- & No flow & -- & -- & No flow & -- & -- \\
\hline 34 & 08176596 & $\begin{array}{l}\text { Twelvemile Creek at Highway } \\
77 \mathrm{~A} / 183 \text { near Meyersville, Tex. }\end{array}$ & No flow & -- & -- & No flow & -- & -- & No flow & -- & -- \\
\hline 37 & 08176750 & $\begin{array}{c}\text { Fivemile Creek at County Road } \\
400 \text { near Meyersville, Tex. }\end{array}$ & No flow & -- & -- & $.27^{\mathrm{a}}$ & $\mathrm{P} / \mathrm{P}$ & .027 & No flow & -- & -- \\
\hline 46 & 08176550 & $\begin{array}{l}\text { Fifteenmile Creek near Weser, } \\
\text { Tex. }\end{array}$ & $0.026^{\mathrm{a}}$ & $\mathrm{P} / \mathrm{P} / \mathrm{P} / \mathrm{P}$ & 0.0026 & $10.6^{\mathrm{a}}$ & $\mathrm{F} / \mathrm{F}$ & .848 & $3.94^{\mathrm{a}}$ & $\mathrm{P} / \mathrm{P}$ & .394 \\
\hline 44 & 08176548 & $\begin{array}{l}\text { Fifteenmile Creek at Audilet } \\
\text { Crossing near Ander, Tex. }\end{array}$ & -- & -- & -- & $9.49 *$ & $\mathrm{U} / \mathrm{U}$ & .949 & -- & -- & -- \\
\hline
\end{tabular}


Table 4. Summary of streamflow-measurement results, measurement error ratings, and potential measurement errors for reaches along Coleto Creek and contributing streams during streamflow-measurement surveys in July 2009, January 2010, and June 2010, upper Coleto Creek watershed, southeast Texas.-Continued

[USGS, U.S. Geological Survey; fts/s, cubic feet per second. Error ratings: F, fair; P, poor; U, unspecified; --, no data]

\begin{tabular}{|c|c|c|c|c|c|c|c|c|c|c|c|}
\hline $\begin{array}{c}\text { Site } \\
\text { identifier } \\
\text { (figs. 4, 6, } \\
\text { 12-15) }\end{array}$ & $\begin{array}{l}\text { USGS } \\
\text { station } \\
\text { number }\end{array}$ & Site name & $\begin{array}{l}\text { 1st gain- } \\
\text { loss survey, } \\
\text { July 29-30, } \\
2009\left(\mathrm{ft}^{3} / \mathrm{s}\right)\end{array}$ & $\begin{array}{l}\text { 1st gain- } \\
\text { loss survey } \\
\text { measure- } \\
\text { ment error } \\
\text { rating }\end{array}$ & $\begin{array}{l}\text { 1st gain- } \\
\text { loss survey } \\
\text { potential } \\
\text { measure- } \\
\text { ment error } \\
\left.\text { (ft }{ }^{3} / \mathrm{s}\right)\end{array}$ & $\begin{array}{c}\text { 2nd gain- } \\
\text { loss survey, } \\
\text { January 11-13, } \\
2010\left(\mathrm{ft}^{3} / \mathrm{s}\right)\end{array}$ & $\begin{array}{l}\text { 2nd gain- } \\
\text { loss survey } \\
\text { measure- } \\
\text { ment error } \\
\text { rating }\end{array}$ & $\begin{array}{c}\text { 2nd gain- } \\
\text { loss survey } \\
\text { potential } \\
\text { measure- } \\
\text { ment error } \\
\left(\mathrm{ft}^{3} / \mathrm{s}\right)\end{array}$ & $\begin{array}{c}\text { 3rd gain- } \\
\text { loss survey, } \\
\text { June 21-22, } \\
2010 \\
\left(\mathrm{ft}^{3} / \mathrm{s}\right)\end{array}$ & $\begin{array}{l}\text { 3rd gain- } \\
\text { loss survey } \\
\text { measure- } \\
\text { ment error } \\
\text { rating }\end{array}$ & $\begin{array}{c}\text { 3rd gain- } \\
\text { loss survey } \\
\text { potential } \\
\text { measure- } \\
\text { ment error } \\
\left(\mathrm{ft}^{3} / \mathrm{s}\right)\end{array}$ \\
\hline 51 & 08176598 & $\begin{array}{l}\text { Twelvemile Creek at Wendel Road } \\
\text { near Meyersville, Tex. }\end{array}$ & No flow & -- & -- & $1.51^{\mathrm{a}}$ & $\mathrm{P} / \mathrm{P}$ & 0.151 & No flow & -- & -- \\
\hline 55 & 08176825 & $\begin{array}{l}\text { Twelvemile Creek at Farm Road } \\
237 \text { near Mission Valley, Tex. }\end{array}$ & No flow & -- & -- & $3.40^{\mathrm{a}}$ & $\mathrm{U} / \mathrm{U}$ & .34 & No flow & -- & -- \\
\hline 62 & 08176565 & $\begin{array}{l}\text { Eighteenmile Creek at Highway } \\
119 \text { at Weesatche, Tex. }\end{array}$ & No flow & -- & -- & $.26^{\mathrm{a}}$ & $\mathrm{U} / \mathrm{U}$ & .026 & $0.05^{\mathrm{a}}$ & $\mathrm{P} / \mathrm{P}$ & 0.005 \\
\hline 70 & 08176580 & $\begin{array}{l}\text { Eighteenmile Creek at Highway } \\
\text { 77A/183 near Ander, Tex. }\end{array}$ & No flow & -- & -- & $1.46^{\mathrm{a}}$ & $\mathrm{U} / \mathrm{U}$ & .146 & $.07^{\mathrm{e}}$ & $\mathrm{P}$ & .007 \\
\hline 76 & 08176555 & $\begin{array}{l}\text { Fifteenmile Creek at Fox Road } \\
\text { near Ander, Tex. }\end{array}$ & No flow & -- & -- & $12.13^{\mathrm{a}}$ & $\mathrm{U} / \mathrm{U}$ & 1.213 & $4.54^{\mathrm{a}}$ & $\mathrm{F} / \mathrm{F}$ & .363 \\
\hline 80 & 08176590 & $\begin{array}{l}\text { Fifteenmile Creek below Eigh- } \\
\text { teenmile Creek near Ander, Tex. }\end{array}$ & -- & -- & -- & $15.88^{\mathrm{a}}$ & $\mathrm{U} / \mathrm{U}$ & 1.588 & $5.85^{\mathrm{a}}$ & $\mathrm{P} / \mathrm{P}$ & .585 \\
\hline 79 & 08176592 & $\begin{array}{l}\text { Fifteenmile Creek near Ander, } \\
\text { Tex. }\end{array}$ & No flow & -- & -- & $17.21^{\mathrm{a}}$ & $\mathrm{U} / \mathrm{U}$ & 1.721 & -- & -- & -- \\
\hline 87 & 08177300 & $\begin{array}{l}\text { Perdido Creek at Farm Road } 622 \\
\text { near Fannin, Tex. }\end{array}$ & No flow & -- & -- & $.23^{\mathrm{a}}$ & $\mathrm{P} / \mathrm{P}$ & .023 & $.04^{\mathrm{e}}$ & $\mathrm{P}$ & .004 \\
\hline 101 & 08177310 & $\begin{array}{l}\text { Perdido Creek at Franke Road } \\
\text { near Fannin, Tex. }\end{array}$ & No flow & -- & -- & -- & -- & -- & -- & -- & -- \\
\hline 90 & 08176900 & $\begin{array}{l}\text { Coleto Creek at Arnold Road } \\
\text { Crossing near Schroeder, Tex. }\end{array}$ & No flow & -- & -- & $24.63^{\mathrm{a}}$ & $\mathrm{F} / \mathrm{F}$ & 1.97 & $5.85^{\mathrm{a}}$ & $\mathrm{F} / \mathrm{F}$ & .468 \\
\hline 97 & 08177000 & Coleto Creek near Schroeder, Tex. & No flow & -- & -- & Backwater & -- & -- & Backwater & -- & -- \\
\hline 99 & 08177270 & $\begin{array}{l}\text { Turkey Creek at Farm Road } 2987 \\
\text { near Fannin, Tex. }\end{array}$ & No flow & -- & -- & $.017^{\mathrm{e}}$ & $\mathrm{U}$ & .0017 & No flow & -- & -- \\
\hline 104 & 08177350 & $\begin{array}{l}\text { Perdido Creek at Farm Road } 2987 \\
\text { near Fannin, Tex. }\end{array}$ & No flow & -- & -- & No flow & -- & -- & No flow & -- & -- \\
\hline
\end{tabular}

${ }^{\mathrm{a}}$ Average of measurements.

*Data not used in gain-loss calculations.

${ }^{\mathrm{e}}$ Estimated. 
Table 5. Gain-loss determinations for reaches along Coleto Creek and contributing streams during three streamflow-measurement surveys in July 2009, January 2010, and June 2010, upper Coleto Creek watershed, southeast Texas.

[ft, feet; $\mathrm{ft}^{3} / \mathrm{s}$, cubic feet per second; bold font indicates gain or loss that is less than potential measurement error for that particular reach]

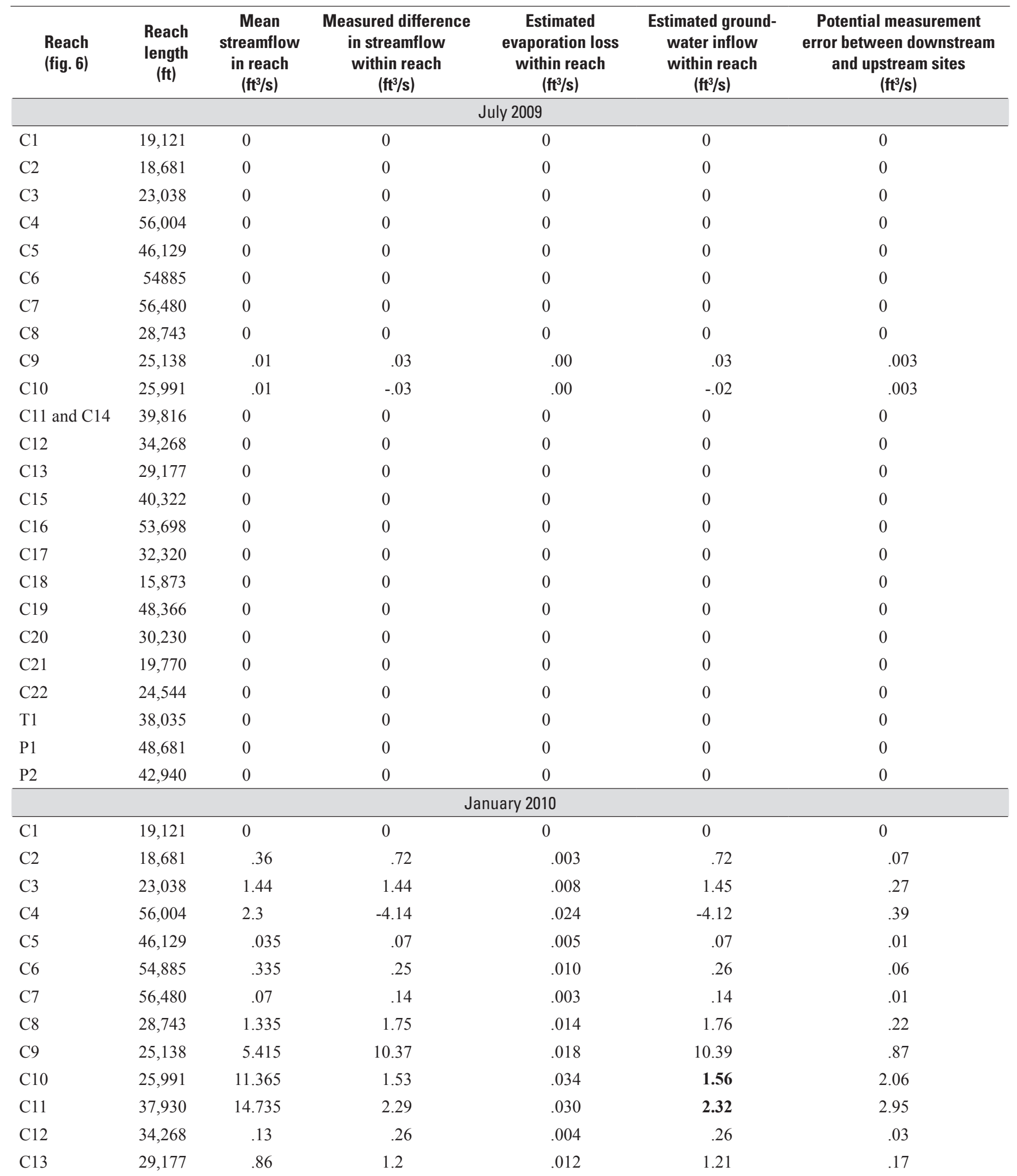


Table 5. Gain-loss determinations for reaches along Coleto Creek and contributing streams during three streamflow-measurement surveys in July 2009, January 2010, and June 2010, upper Coleto Creek watershed, southeast Texas.-Continued

$\left[\mathrm{ft}^{3} / \mathrm{s}\right.$, cubic feet per second; bold font indicates gain or loss that is less than potential measurement error for that particular reach]

\begin{tabular}{|c|c|c|c|c|c|c|}
\hline $\begin{array}{l}\text { Reach } \\
\text { (fig. 6) }\end{array}$ & $\begin{array}{c}\text { Reach } \\
\text { length } \\
\text { (ft) }\end{array}$ & $\begin{array}{l}\text { Mean } \\
\text { streamflow } \\
\text { in reach } \\
\left(\mathrm{ft}^{3} / \mathrm{s}\right)\end{array}$ & $\begin{array}{l}\text { Measured difference } \\
\text { in streamflow } \\
\text { within reach } \\
\left(\mathrm{ft}^{3} / \mathrm{s}\right)\end{array}$ & $\begin{array}{c}\text { Estimated } \\
\text { evaporation loss } \\
\text { within reach } \\
\left(\mathrm{ft}^{3} / \mathrm{s}\right)\end{array}$ & $\begin{array}{c}\text { Estimated ground- } \\
\text { water inflow } \\
\text { within reach } \\
\left(\mathrm{ft}^{3} / \mathrm{s}\right)\end{array}$ & $\begin{array}{l}\text { Potential measurement } \\
\text { error between downstream } \\
\text { and upstream sites } \\
\left(\mathrm{ft}^{3} / \mathrm{s}\right)\end{array}$ \\
\hline \multicolumn{7}{|c|}{ January 2010-Continued } \\
\hline $\mathrm{C} 14$ & 1,886 & 16.545 & 1.33 & 0.002 & 1.33 & 3.31 \\
\hline $\mathrm{C} 15$ & 40,322 & 22.62 & 4.02 & .057 & 4.08 & 4.03 \\
\hline $\mathrm{C} 16$ & 53,698 & .135 & .27 & .007 & .28 & .02 \\
\hline $\mathrm{C} 17$ & 32,320 & .135 & -.27 & .004 & -.27 & .02 \\
\hline $\mathrm{C} 18$ & 15,873 & .755 & 1.51 & .003 & 1.51 & .15 \\
\hline C19 & 48,366 & 2.59 & 1.62 & .029 & 1.65 & .52 \\
\hline $\mathrm{C} 20$ & 30,230 & 0 & 0 & 0 & 0 & 0 \\
\hline $\mathrm{C} 21$ & 19,770 & 0 & 0 & 0 & 0 & 0 \\
\hline $\mathrm{C} 22$ & 24,544 & .135 & .27 & .004 & .27 & .03 \\
\hline $\mathrm{T} 1$ & 38,035 & .0085 & .017 & .001 & .02 & .002 \\
\hline P1 & 48,681 & .115 & .23 & .013 & .24 & .02 \\
\hline P2 & 42,940 & .115 & -.23 & .012 & -.22 & .02 \\
\hline \multicolumn{7}{|c|}{ June 2010} \\
\hline $\mathrm{C} 1$ & 19,121 & 0 & 0 & 0 & 0 & 0 \\
\hline $\mathrm{C} 2$ & 18,681 & .15 & .3 & .007 & .31 & .03 \\
\hline $\mathrm{C} 3$ & 23,038 & .565 & .53 & .023 & .55 & .11 \\
\hline $\mathrm{C} 4$ & 56,004 & 2.5 & .78 & .080 & .86 & .38 \\
\hline $\mathrm{C} 5$ & 46,129 & 0 & 0 & 0 & 0 & 0 \\
\hline C6 & 54,885 & 0 & 0 & 0 & 0 & 0 \\
\hline $\mathrm{C} 7$ & 56,480 & 0 & 0 & 0 & 0 & 0 \\
\hline $\mathrm{C} 8$ & 28,743 & .64 & 1.28 & .021 & 1.30 & .013 \\
\hline $\mathrm{C} 9$ & 25,138 & 3.415 & 1.05 & .042 & 1.09 & .68 \\
\hline $\mathrm{C} 10$ & 25,991 & 4.24 & .6 & .057 & .66 & .76 \\
\hline $\mathrm{C} 11$ & 37,930 & 5.23 & 1.24 & .039 & 1.28 & .96 \\
\hline $\mathrm{C} 12$ & 34,268 & .025 & .05 & .012 & .06 & .005 \\
\hline $\mathrm{C} 13$ & 29,177 & .06 & .02 & .015 & .04 & .01 \\
\hline $\mathrm{C} 14$ and $\mathrm{C} 15$ & 42,208 & 5.85 & 0 & .093 & .09 & 1.05 \\
\hline $\mathrm{C} 16$ & 53,698 & 0 & 0 & 0 & 0 & 0 \\
\hline $\mathrm{C} 17$ & 32,320 & 0 & 0 & 0 & 0 & 0 \\
\hline $\mathrm{C} 18$ & 15,873 & 0 & 0 & 0 & 0 & 0 \\
\hline C19 & 48,366 & 0 & 0 & 0 & 0 & 0 \\
\hline $\mathrm{C} 20$ & 30,230 & 0 & 0 & 0 & 0 & 0 \\
\hline $\mathrm{C} 21$ & 19,770 & 0 & 0 & 0 & 0 & 0 \\
\hline $\mathrm{C} 22$ & 24,544 & 0 & 0 & 0 & 0 & 0 \\
\hline $\mathrm{T} 1$ & 38,035 & 0 & 0 & 0 & 0 & 0 \\
\hline P1 & 48,681 & .02 & .04 & .005 & .04 & .004 \\
\hline $\mathrm{P} 2$ & 42,940 & .02 & -.04 & .004 & -.04 & .004 \\
\hline
\end{tabular}




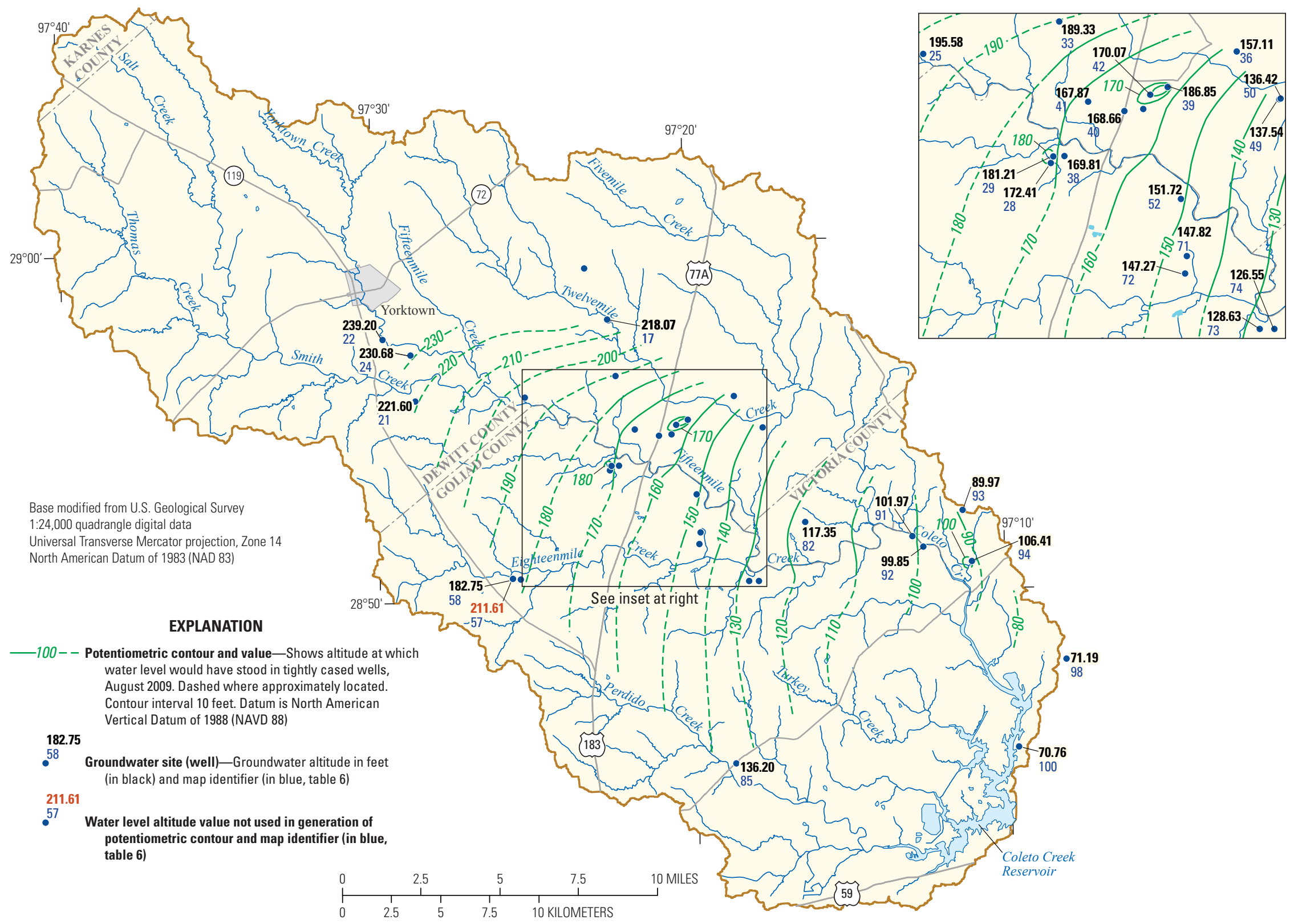

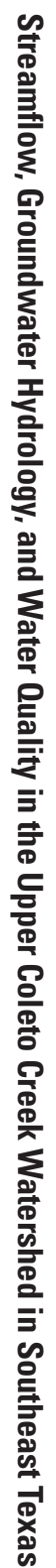

Figure 7. Potentiometric surface of the Evangeline aquifer in the upper Coleto Creek watershed, southeast Texas, August 2009 


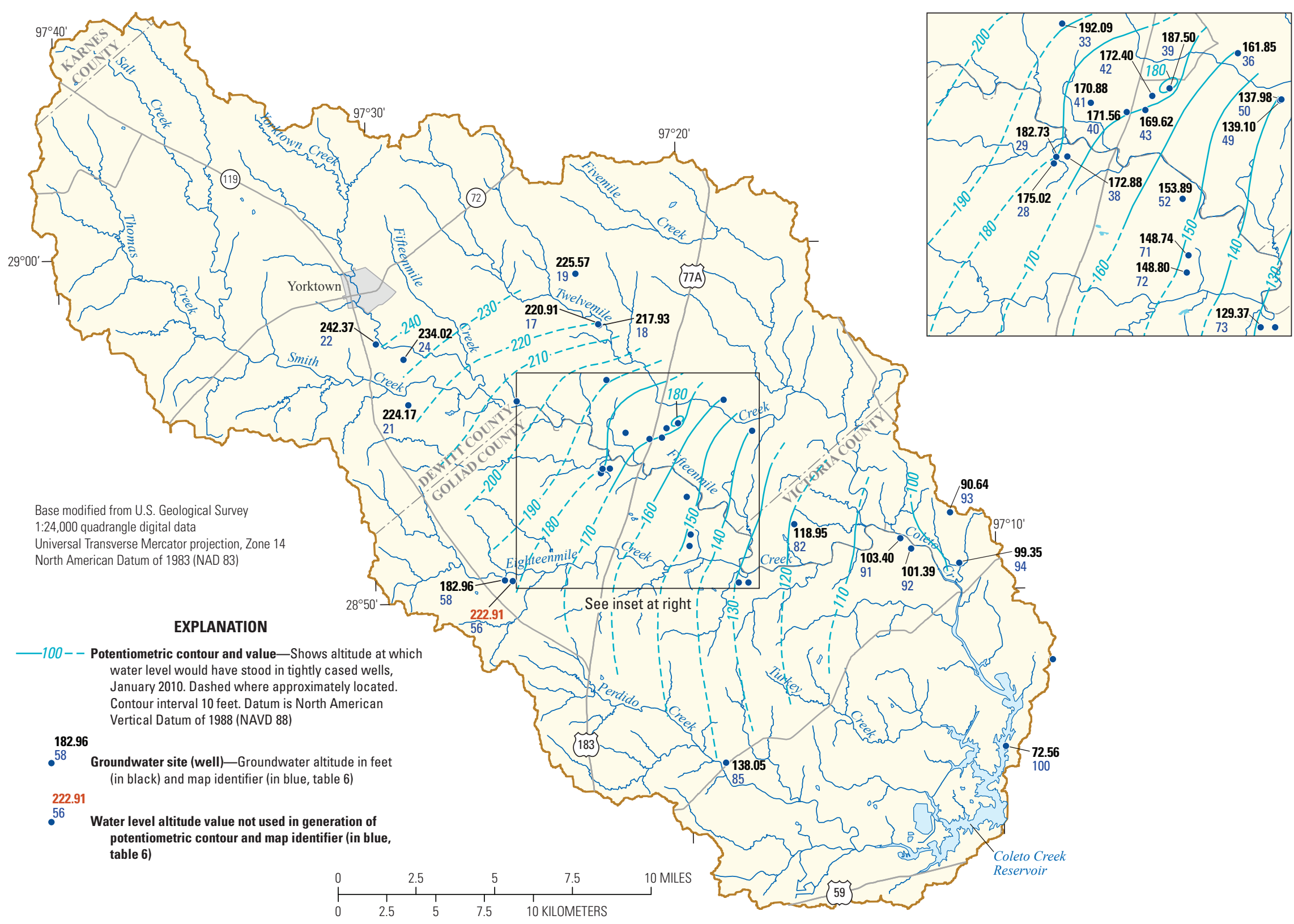

Figure 8. Potentiometric surface of the Evangeline aquifer in the upper Coleto Creek watershed, southeast Texas, January 2010. 


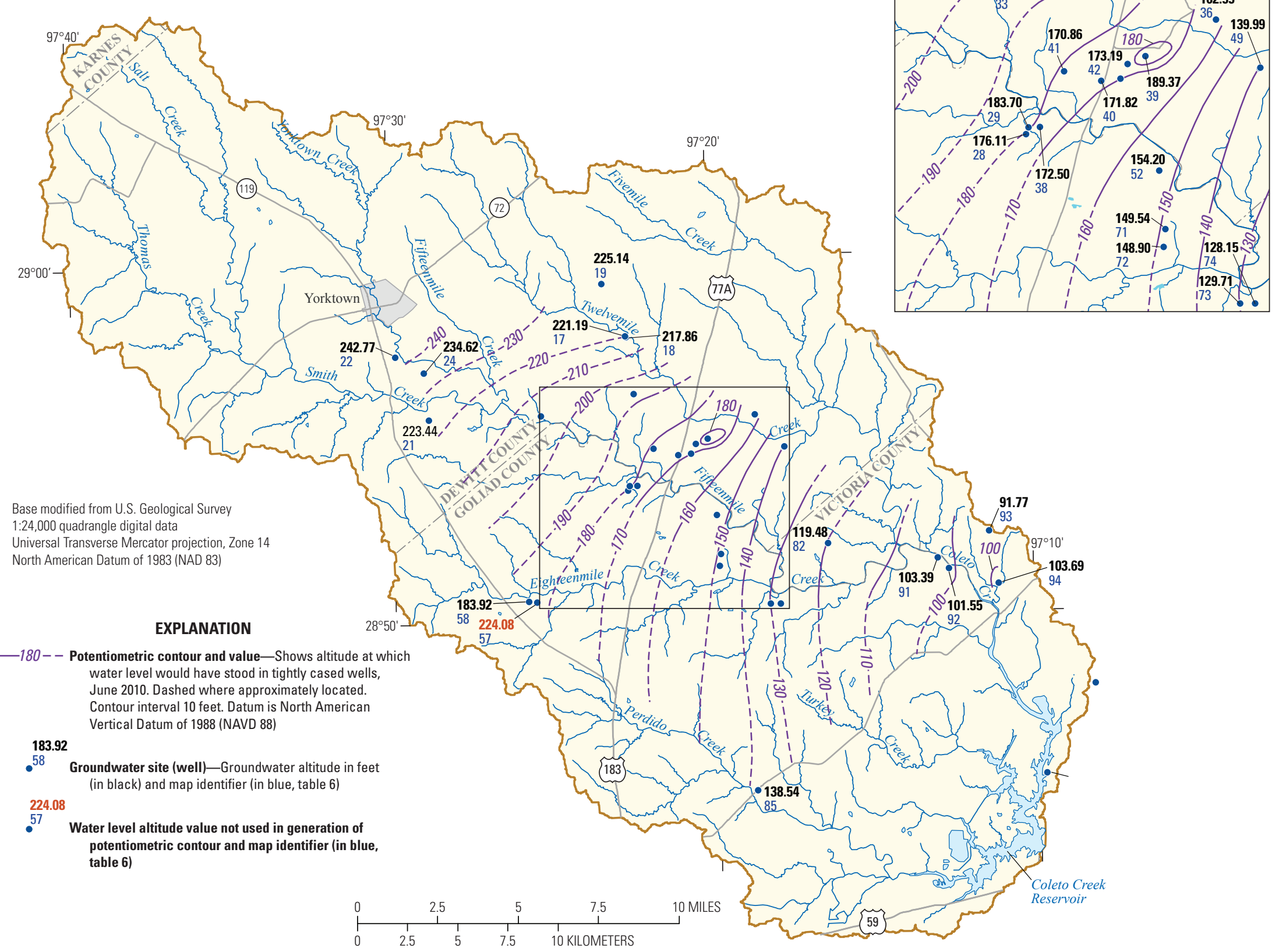

Figure 9. Potentiometric surface of the Evangeline aquifer in the upper Coleto Creek watershed, southeast Texas, June 2010. 


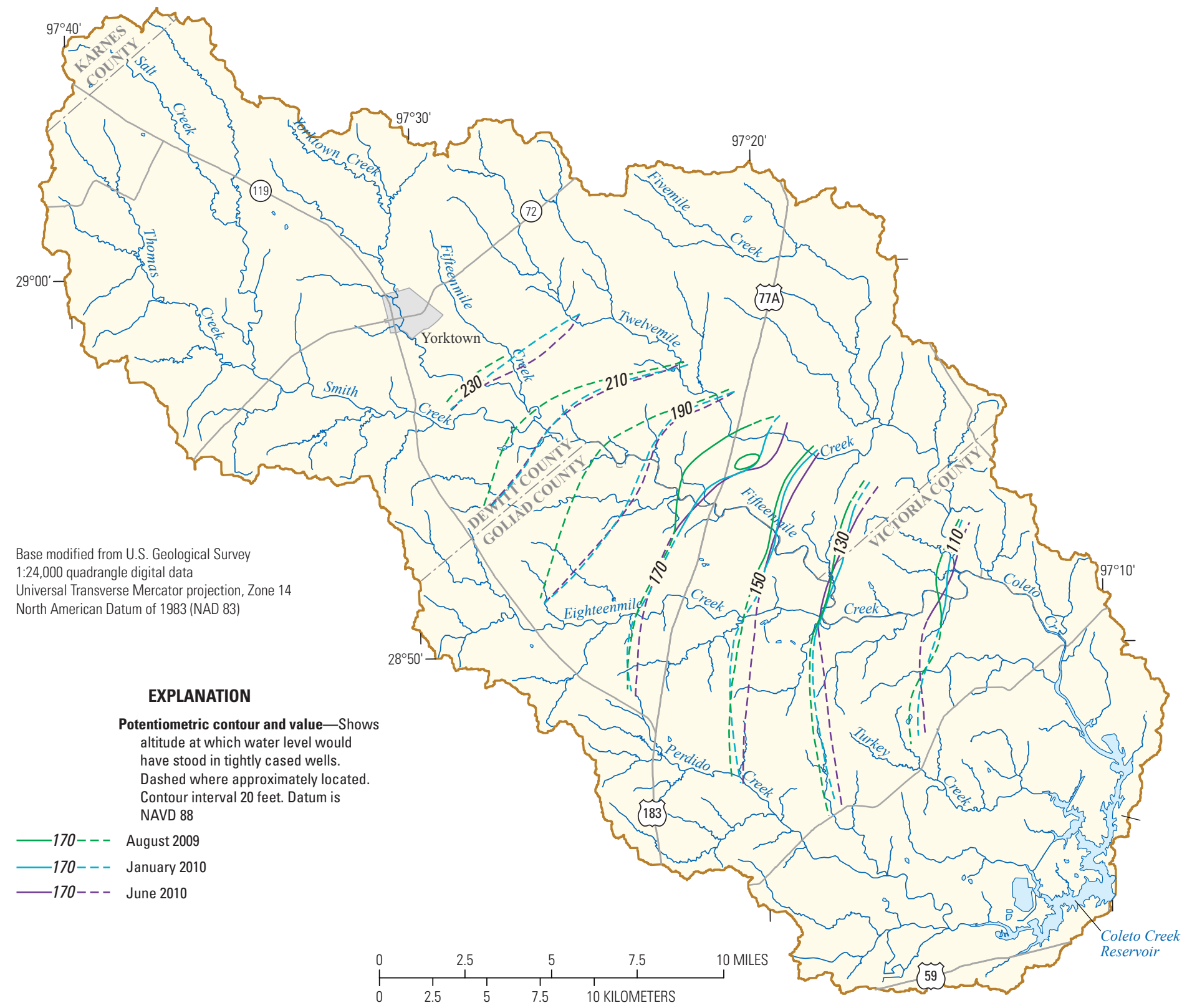

Figure 10. Comparison of potentiometric contours of the Evangeline aquifer in the upper Coleto Creek watershed, southeast Texas, during three synoptic measurement events, August 2009, January 2010, and June 2010. 
Table 6. Groundwater-level altitude measurements at selected wells in the upper Coleto Creek watershed, southeast Texas, August 2009-June 2010. [USGS, U.S. Geological Survey; NAVD 88, North American Vertical Datum of 1988; --, not measured; n/a, not available]

\begin{tabular}{|c|c|c|c|c|c|c|c|c|c|c|c|c|c|c|}
\hline $\begin{array}{c}\text { Site } \\
\text { identifier } \\
\text { (figs. 4, 6, } \\
\text { 12-15) }\end{array}$ & County & $\begin{array}{c}\text { USGS } \\
\text { station number }\end{array}$ & $\begin{array}{l}\text { State well } \\
\text { number }\end{array}$ & $\begin{array}{l}\text { Elevation } \\
\text { of land } \\
\text { surface } \\
\text { (feet above } \\
\text { NAVD 88)' }\end{array}$ & $\begin{array}{l}\text { Well depth } \\
\text { (feet) }\end{array}$ & $\begin{array}{l}\text { Date of } \\
\text { measure- } \\
\text { ment during } \\
\text { the first } \\
\text { round of } \\
\text { sampling }\end{array}$ & $\begin{array}{l}\text { First round, } \\
\text { water level } \\
\text { (feet below } \\
\text { land } \\
\text { surface) }\end{array}$ & $\begin{array}{l}\text { First round, } \\
\text { ground- } \\
\text { water-level } \\
\text { altitude } \\
\text { (feet above } \\
\text { NAVD 88) }\end{array}$ & $\begin{array}{l}\text { Date of } \\
\text { measure- } \\
\text { ment during } \\
\text { the second } \\
\text { round of } \\
\text { sampling }\end{array}$ & $\begin{array}{c}\text { Second } \\
\text { round, } \\
\text { water level } \\
\text { (feet below } \\
\text { land } \\
\text { surface) }\end{array}$ & $\begin{array}{c}\text { Second } \\
\text { round, } \\
\text { ground- } \\
\text { water-level } \\
\text { altitude } \\
\text { (feet above } \\
\text { NAVD 88) }\end{array}$ & $\begin{array}{l}\text { Date of } \\
\text { measure- } \\
\text { ment during } \\
\text { the third } \\
\text { round of } \\
\text { sampling }\end{array}$ & $\begin{array}{c}\text { Third round, } \\
\text { water level } \\
\text { (feet below } \\
\text { land } \\
\text { surface) }\end{array}$ & $\begin{array}{l}\text { Third round, } \\
\text { ground- } \\
\text { water-level } \\
\text { altitude } \\
\text { (feet above } \\
\text { NAVD 88) }\end{array}$ \\
\hline 17 & De Witt & 285750097224001 & 79-05-303 & 244.36 & 148 & $8 / 4 / 2009$ & 26.29 & 218.07 & $1 / 12 / 2010$ & 23.45 & 220.91 & $6 / 23 / 2010$ & 23.17 & 221.19 \\
\hline 18 & De Witt & 285752097224201 & $79-05-304$ & 248.30 & 44 & $8 / 4 / 2009$ & -- & -- & $1 / 12 / 2010$ & 30.37 & 217.93 & $6 / 23 / 2010$ & 30.44 & 217.86 \\
\hline 19 & De Witt & 285919097232301 & 79-05-305 & 296.87 & 200 & -- & -- & -- & $1 / 12 / 2010$ & 71.30 & 225.57 & $6 / 23 / 2010$ & 71.73 & 225.14 \\
\hline 21 & De Witt & 285541097285301 & $79-05-407$ & 280.23 & 130 & $8 / 12 / 2009$ & 58.63 & 221.60 & $1 / 22 / 2010$ & 56.06 & 224.17 & $6 / 23 / 2010$ & 56.79 & 223.44 \\
\hline 22 & De Witt & 285726097295301 & 79-05-406 & 251.56 & 160 & $8 / 12 / 2009$ & 12.36 & 239.20 & $1 / 12 / 2010$ & 9.19 & 242.37 & $6 / 23 / 2010$ & 8.79 & 242.77 \\
\hline 24 & De Witt & 285658097290101 & 79-05-408 & 252.08 & 181 & 8/4/2009 & 21.40 & 230.68 & $1 / 12 / 2010$ & 18.06 & 234.02 & $6 / 23 / 2010$ & 17.46 & 234.62 \\
\hline 25 & De Witt & 285543097252301 & $79-05-505$ & 210.88 & -- & $8 / 4 / 2009$ & 15.30 & 195.58 & $\mathrm{n} / \mathrm{a}^{2}$ & -- & -- & $\mathrm{n} / \mathrm{a}^{2}$ & -- & -- \\
\hline 28 & Goliad & 285337097224301 & 79-05-903 & 217.33 & 280 & $8 / 12 / 2009$ & 44.92 & 172.41 & $1 / 13 / 2010$ & 42.31 & 175.02 & $6 / 22 / 2010$ & 41.22 & 176.11 \\
\hline 29 & Goliad & 285344097224001 & 79-05-904 & 199.37 & 164 & $8 / 12 / 2009$ & 18.16 & 181.21 & $1 / 13 / 2010$ & 16.64 & 182.73 & $6 / 22 / 2010$ & 15.67 & 183.70 \\
\hline 33 & De Witt & 285616097222801 & 79-06-411 & 272.23 & 230 & $8 / 5 / 2009$ & 82.90 & 189.33 & $1 / 12 / 2010$ & 80.14 & 192.09 & $6 / 23 / 2010$ & 79.60 & 192.63 \\
\hline 36 & De Witt & 285537097184201 & $79-06-506$ & 219.68 & 120 & $8 / 12 / 2009$ & 62.57 & 157.11 & $1 / 12 / 2010$ & 57.83 & 161.85 & $6 / 23 / 2010$ & 57.13 & 162.55 \\
\hline 38 & Goliad & 285345097222501 & $79-06-712$ & 211.87 & 103 & $8 / 12 / 2009$ & 42.06 & 169.81 & $1 / 13 / 2010$ & 38.99 & 172.88 & $6 / 22 / 2010$ & 39.37 & 172.50 \\
\hline 39 & De Witt & 285459097201101 & 79-06-703 & 243.19 & 73 & $8 / 12 / 2009$ & 56.34 & 186.85 & $1 / 22 / 2010$ & 55.69 & 187.50 & $6 / 23 / 2010$ & 53.82 & 189.37 \\
\hline 40 & De Witt & 285434097191901 & $79-06-807$ & 212.03 & 113 & $8 / 5 / 2009$ & 43.37 & 168.66 & $1 / 12 / 2010$ & 40.47 & 171.56 & $6 / 23 / 2010$ & 40.21 & 171.82 \\
\hline 41 & De Witt & 285445097215301 & 79-06-709 & 219.61 & 120 & $8 / 5 / 2009$ & 51.74 & 167.87 & $1 / 12 / 2010$ & 48.73 & 170.88 & $6 / 23 / 2010$ & 48.75 & 170.86 \\
\hline 42 & De Witt & 285451097203401 & 79-06-710 & 229.95 & 137 & $8 / 12 / 2009$ & 59.88 & 170.07 & $1 / 22 / 2010$ & 57.55 & 172.40 & $6 / 23 / 2010$ & 56.76 & 173.19 \\
\hline 43 & De Witt & 285435097204301 & 79-06-707 & 202.19 & 125 & $8 / 12 / 2009$ & 36.14 & 166.05 & $1 / 22 / 2010$ & 32.57 & 169.62 & $6 / 23 / 2010$ & -- & -- \\
\hline 49 & De Witt & 285443097174801 & 79-06-808 & 201.64 & 150 & 8/6/2009 & 64.10 & 137.54 & $1 / 12 / 2010$ & 62.54 & 139.10 & $6 / 23 / 2010$ & 61.65 & 139.99 \\
\hline 50 & De Witt & 285443097174802 & 79-06-809 & 199.72 & 125 & $8 / 6 / 2009$ & 63.30 & 136.42 & $1 / 12 / 2010$ & 61.74 & 137.98 & $6 / 23 / 2010$ & -- & -- \\
\hline 52 & Goliad & 285254097195801 & $79-06-810$ & 192.97 & 180 & $8 / 5 / 2009$ & 41.25 & 151.72 & $1 / 13 / 2010$ & 39.08 & 153.89 & $6 / 22 / 2010$ & 38.77 & 154.20 \\
\hline 56 & Goliad & 285037097253901 & $79-13-231$ & 233.86 & -- & -- & -- & -- & $1 / 13 / 2010$ & 10.95 & 222.91 & $6 / 22 / 2010$ & 9.41 & 224.45 \\
\hline 57 & Goliad & 285038097255402 & $79-13-224$ & 234.62 & -- & $8 / 5 / 2009$ & 23.01 & 211.61 & $\mathrm{n} / \mathrm{a}^{3}$ & -- & -- & $6 / 22 / 2010$ & 10.54 & 224.08 \\
\hline 58 & Goliad & 285038097255401 & $79-13-225$ & 233.37 & 65 & $8 / 5 / 2009$ & 50.62 & 182.75 & $1 / 13 / 2010$ & 50.41 & 182.96 & $6 / 22 / 2010$ & 49.45 & 183.92 \\
\hline 71 & Goliad & 285149097195201 & $79-14-204$ & 231.42 & 122 & 8/6/2009 & 83.60 & 147.82 & $1 / 13 / 2010$ & 82.68 & 148.74 & $6 / 22 / 2010$ & 81.88 & 149.54 \\
\hline 72 & Goliad & 285129097195401 & $79-14-202$ & 182.66 & 88 & $8 / 12 / 2009$ & 35.39 & 147.27 & $1 / 13 / 2010$ & 33.86 & 148.80 & $6 / 23 / 2010$ & 33.76 & 148.90 \\
\hline 73 & Goliad & 285025097182101 & $79-14-205$ & 168.74 & 346 & 8/6/2009 & 40.11 & 128.63 & $1 / 14 / 2010$ & 39.37 & 129.37 & $6 / 22 / 2010$ & 39.03 & 129.71 \\
\hline 74 & Goliad & 285025097180201 & $79-14-203$ & 172.09 & 380 & $8 / 12 / 2009$ & 45.54 & 126.55 & -- & -- & -- & $6 / 22 / 2010$ & 43.94 & 128.15 \\
\hline 82 & Victoria & 285203097163001 & $79-14-303$ & 204.51 & 222 & $8 / 12 / 2009$ & 87.16 & 117.35 & $1 / 13 / 2010$ & 85.56 & 118.95 & $6 / 21 / 2010$ & 85.03 & 119.48 \\
\hline 85 & Goliad & 284518097185401 & $79-14-804$ & 169.16 & 270 & 8/6/2009 & 32.96 & 136.20 & $1 / 11 / 2010$ & 31.11 & 138.05 & $6 / 24 / 2010$ & 30.62 & 138.54 \\
\hline 91 & Goliad & 285134097130601 & $79-15-101$ & 127.02 & 133 & 8/6/2009 & 25.05 & 101.97 & $1 / 14 / 2010$ & 23.62 & 103.40 & $6 / 24 / 2010$ & 23.63 & 103.39 \\
\hline 92 & Goliad & 285116097124501 & $79-15-102$ & 125.12 & 132 & $8 / 12 / 2009$ & 25.27 & 99.85 & $1 / 13 / 2010$ & 23.73 & 101.39 & $6 / 22 / 2010$ & 23.57 & 101.55 \\
\hline 93 & Victoria & 285216097112801 & $79-15-205$ & 189.55 & -- & 8/7/2009 & 99.58 & 89.97 & $1 / 13 / 2010$ & 98.91 & 90.64 & $6 / 21 / 2010$ & 97.78 & 91.77 \\
\hline 94 & Victoria & 285049097111201 & $79-15-206$ & 147.86 & 121 & $8 / 7 / 2009$ & 41.45 & 106.41 & $1 / 13 / 2010$ & 48.51 & 99.35 & $6 / 21 / 2010$ & 44.17 & 103.69 \\
\hline 98 & Victoria & 284801097081601 & $79-15-604$ & 133.50 & -- & $8 / 7 / 2009$ & 62.31 & 71.19 & $\mathrm{n} / \mathrm{a}^{3}$ & -- & -- & $\mathrm{n} / \mathrm{a}^{3}$ & -- & -- \\
\hline 100 & Victoria & 284535097095101 & $79-15-904$ & 106.67 & -- & $8 / 7 / 2009$ & 35.91 & 70.76 & $1 / 14 / 2010$ & 34.11 & 72.56 & $6 / 21 / 2010$ & 33.88 & 72.79 \\
\hline 108 & Goliad & 285345097215201 & 79-06-713 & 206.30 & -- & -- & -- & -- & $1 / 13 / 2010$ & 32.60 & 173.70 & $6 / 22 / 2010$ & 34.89 & 171.41 \\
\hline
\end{tabular}

${ }^{1}$ Elevation obtained from digital elevation model data.

${ }^{2}$ Well deactivated by Texas Commission of Environmental Quality (TCEQ) on 10/18/2009.

${ }^{3}$ Well deactivated by TCEQ on 11/4/2009. 


\section{Nutrients}

Compounds rich in nitrogen and phosphorous, which are also referred to as nutrients, are essential to the health of plants and animals and occur naturally in water. Elevated concentrations of nutrients such as nitrate, which has a USEPA MCL of $10.0 \mathrm{mg} / \mathrm{L}$, can cause adverse affects in humans, particularly infants (U.S. Environmental Protection Agency, 2010). In 1999, the USGS reported on a study that investigated nutrient data from natural settings across the country and estimated a national average concentration of naturally occurring nitrate (sum of nitrate plus nitrite; contribution of nitrite to sum commonly is negligible) in groundwater of $2.0 \mathrm{mg} / \mathrm{L}$, reported as nitrogen. The same study also indicated that human activities have increased nutrients above background concentrations, and nitrate concentrations greater than $2.0 \mathrm{mg} / \mathrm{L}$ are often a result of livestock operations, proximity of wells to septic systems, irrigation intensity, and application and storage of fertilizers and manure. The effects of these anthropogenic activities on nitrate concentrations in groundwater might also be modified by soil characteristics, topography, precipitation quantity, and the presence or absence of confining layers above the aquifer (U.S. Geological Survey, 1999).

Nitrite was detected in 8 of the 42 samples collected, including 6 of 8 surface-water samples. Nitrite concentrations were very low (less than $0.04 \mathrm{mg} / \mathrm{L}$ as nitrogen in all cases) for all detections. Nitrate (as nitrate plus nitrite) was detected in all but three samples (fig. 13); nitrite contributions to nitrate were negligible (table 7). Nitrate concentrations exceeded the threshold concentration $(2.0 \mathrm{mg} / \mathrm{L}$ as nitrogen) associated with anthropogenic sources at only 3 of the 19 sites (State wells 79-06-411, 79-14-204, and Audilet Spring. State wells 79-06-411 and 79-14-204 are within about a 3-mi radius of Audilet Spring; all other sites within that radius exhibited slightly elevated nitrate concentrations ( 1.07 to $1.52 \mathrm{mg} / \mathrm{L}$ ) relative to the remaining sites in the study area, and nitrate concentrations less than $1.00 \mathrm{mg} / \mathrm{L}$ were measured in 24 out of 29 samples collected at these other sites.

\section{Trace Elements}

Many trace elements are beneficial in small quantities to the health of living things, but small increases in concentrations can result in negative health impacts (Maugh, 1973). Trace elements typically occur naturally in water at concentrations much less than $1 \mathrm{mg} / \mathrm{L}$ and are caused by water interacting with surrounding geological deposits (Hem, 1985). Anthropogenic sources of trace elements include pesticides, fossil fuels, paints, construction and plumbing materials, and corrosion inhibitors. Because of wide distribution of both natural and anthropogenic sources of trace elements, the possibility exists for either the occurrence or increased occurrence of some trace elements in water. Of the 23 trace elements for which water was analyzed as part of this study (table 7), all but selenium are classified as metals or metalloids.

The following trace elements were detected in all 42 of the samples: barium, cobalt, lithium, molybdenum, nickel, strontium, vanadium, arsenic, boron, selenium, and uranium. The detection frequencies for the remaining trace elements were as follows: manganese (40), chromium (39), lead (38), antimony (30), zinc (28), copper (27), iron (21), aluminum (16), cadmium (14), beryllium (13), silver (4), and thallium (1).

Public drinking-water standards or guidelines have not yet been established for 3 of the 23 trace elements on the analytical schedule: cobalt, lithium, and vanadium. Of the 20 remaining trace elements, measured concentrations were less than established public drinking-water standards in all samples for all but 2 elements, arsenic and manganese. Arsenic concentrations exceeded the USEPA Maximum Contaminant Level (MCL) (2010) of $10 \mu \mathrm{g} / \mathrm{L}$ (U.S. Environmental Protection Agency, 2010) in two samples (one collected at station 08177300 on Perdido Creek on June 21, 2010, and one collected from Audilet Spring on January 13, 2010). Potential health effects associated with excessive arsenic concentrations in drinking water include cardiovascular disease, increased cancer risk, diabetes, and anemia (U.S. Environmental Protection Agency, 2000). Arsenic occurs naturally, particularly in sulfide-rich rocks, and might also be associated with iron oxides on mineral surfaces. Potential anthropogenic sources of arsenic in the study area include pesticides, food additives for swine and poultry, wood preservatives, and petroleum products (Welch and others, 2000). Manganese concentrations exceeded the USEPA SMCL of $50 \mu \mathrm{g} / \mathrm{L}$ (U.S. Environmental Protection Agency, 2000) in seven of the 42 samples collected; these included both samples collected at USGS station 08176540 Yorktown Creek at County Road 452 near Yorktown, Tex., both samples collected at station 08177300 on Perdido Creek, and all three samples collected at State well 79-15-904. Manganese is ubiquitous in the environment and might be found in many types of rock and soil; it might also be released into the air by iron and steel production plants, powerplants, and coke ovens (Agency for Toxic Substances and Disease Registry, 2008). Manganese can impart a color, odor, or taste to drinking water at concentrations greater than $50 \mu \mathrm{g} / \mathrm{L}$, but health effects are not a concern until concentrations are approximately 10 times higher (Connecticut Department of Public Health, 2011). All three samples collected from State well 79-15-904 had concentrations in excess of $500 \mu \mathrm{g} / \mathrm{L}$ (716 $\mu \mathrm{g} / \mathrm{L}$ on August 7, 2009; 1,970 $\mu \mathrm{g} / \mathrm{L}$ on January 14, 2010; and $2,460 \mu \mathrm{g} / \mathrm{L}$ on June 21, 2010). 
Table 7. Water-quality data collected from surface-water, groundwater, and spring sites, upper Coleto Creek watershed, southeast Texas, August 2009-June 2010.

[USGS, U.S. Geological Survey; --, no data or not applicable; <, less than; E, estimated; ${ }^{\circ} \mathrm{C}$, degrees Celsius; mg/L, milligrams per liter; $\mu \mathrm{g} / \mathrm{L}$, micrograms per liter]

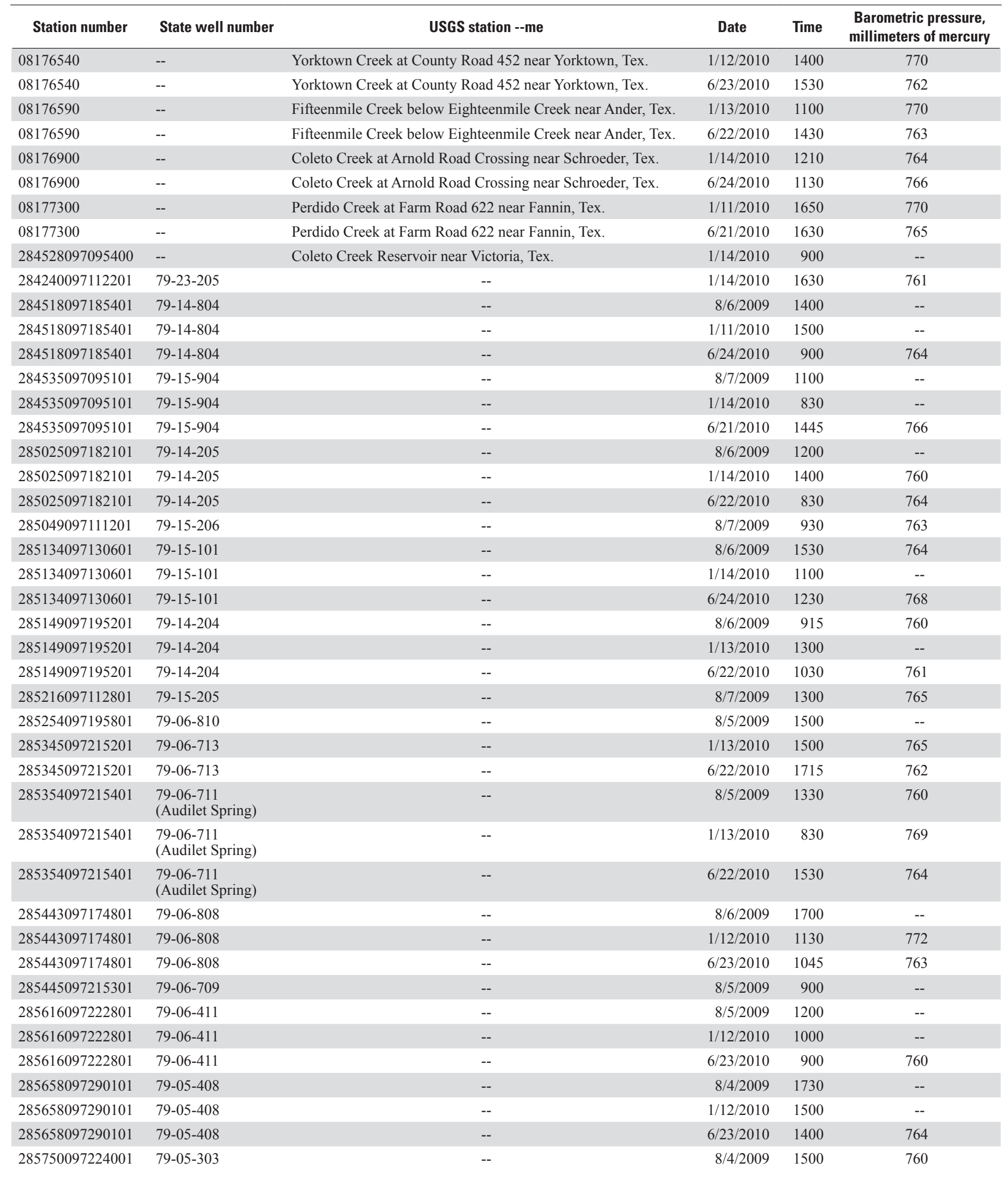


Table 7. Water-quality data collected from surface-water, groundwater, and spring sites, upper Coleto Creek watershed, southeast Texas, August 2009-June 2010.-Continued

[USGS, U.S. Geological Survey; --, no data or not applicable; <, less than; E, estimated; ${ }^{\circ} \mathrm{C}$, degrees Celsius; mg/L, milligrams per liter; $\mu \mathrm{g} / \mathrm{L}$, micrograms per liter]

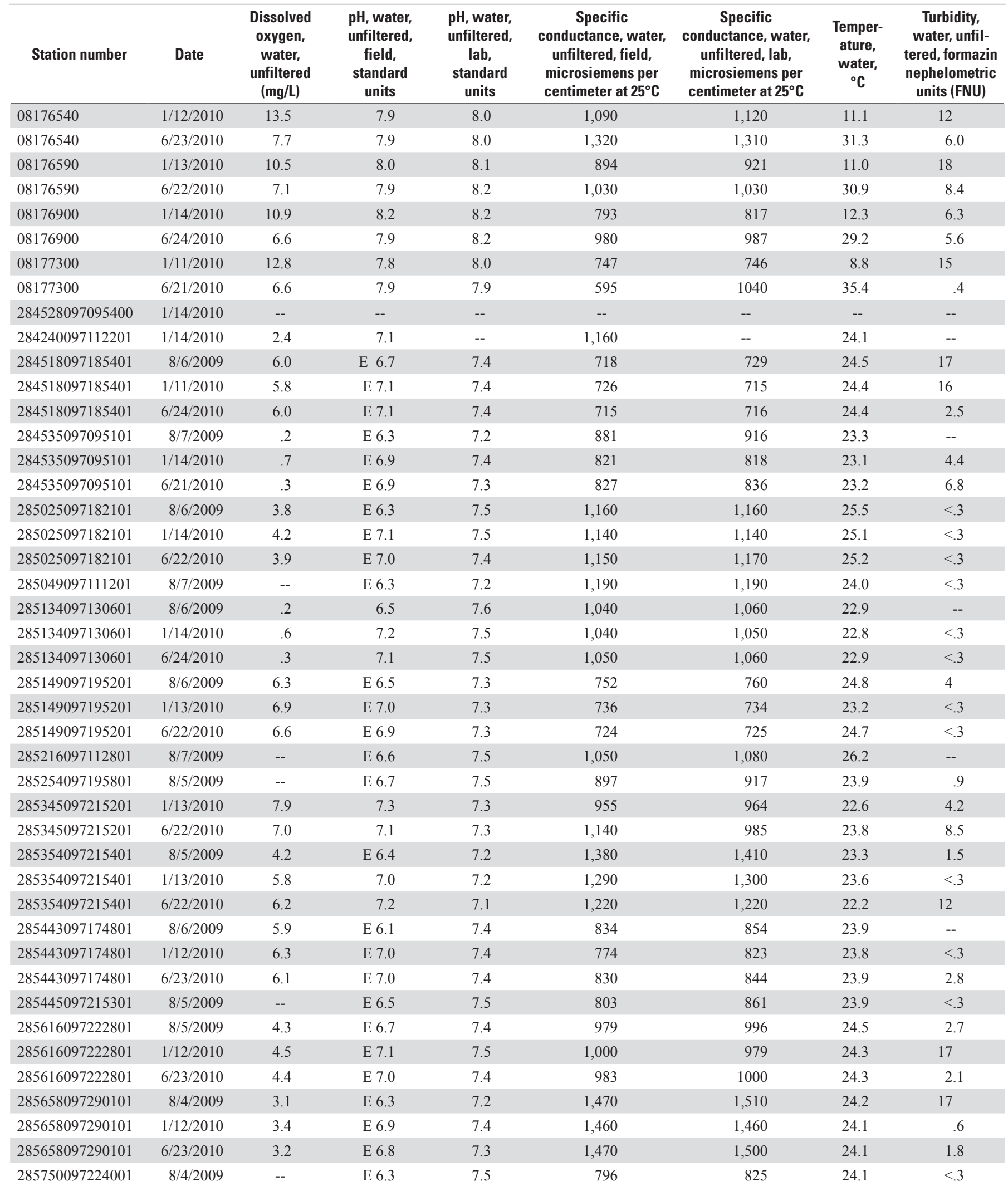


Table 7. Water-quality data collected from surface-water, groundwater, and spring sites, upper Coleto Creek watershed, southeast Texas, August 2009-June 2010.-Continued

[USGS, U.S. Geological Survey; --, no data or not applicable; <, less than; E, estimated; ${ }^{\circ} \mathrm{C}$, degrees Celsius; mg/L, milligrams per liter; $\mu \mathrm{g} / \mathrm{L}$, micrograms per liter]

\begin{tabular}{|c|c|c|c|c|c|c|c|c|c|}
\hline Station number & Date & $\begin{array}{c}\text { Dissolved solids } \\
\text { dried at } 180^{\circ} \mathrm{C}, \\
\text { water, filtered } \\
(\mathrm{mg} / \mathrm{L})\end{array}$ & $\begin{array}{c}\text { Hardness, } \\
\text { water, } \\
\text { (mg/L as } \\
\mathrm{CaCO}_{3} \text { ) }\end{array}$ & $\begin{array}{c}\text { Calcium, } \\
\text { water, } \\
\text { filtered } \\
\text { (mg/L) }\end{array}$ & $\begin{array}{c}\text { Magnesium, } \\
\text { water, } \\
\text { filtered } \\
\text { (mg/L) }\end{array}$ & $\begin{array}{l}\text { Potassium, } \\
\text { water, } \\
\text { filtered } \\
\text { (mg/L) }\end{array}$ & $\begin{array}{c}\text { Sodium } \\
\text { adsorp- } \\
\text { tion ratio, } \\
\text { water, } \\
\text { number }\end{array}$ & $\begin{array}{c}\text { Sodium, } \\
\text { water, } \\
\text { filtered } \\
\text { (mg/L) }\end{array}$ & $\begin{array}{c}\text { Alkalinity, water, } \\
\text { filtered, field } \\
\text { (mg/L as } \mathrm{CaCO}_{3} \text { ) }\end{array}$ \\
\hline 08176540 & $1 / 12 / 2010$ & 710 & 280 & 94.9 & 10.3 & 7.69 & 2.93 & 113 & 274 \\
\hline 08176540 & $6 / 23 / 2010$ & 769 & 331 & 111 & 13.0 & 8.62 & 3.43 & 143 & 286 \\
\hline 08176590 & $1 / 13 / 2010$ & 566 & 296 & 101 & 10.2 & 3.40 & 1.58 & 62.2 & 271 \\
\hline 08176900 & $1 / 14 / 2010$ & 498 & 263 & 91.1 & 8.39 & 3.24 & 1.43 & 53.1 & 243 \\
\hline 08176900 & $6 / 24 / 2010$ & 583 & 319 & 108 & 11.7 & 4.11 & 2.00 & 82.1 & 258 \\
\hline 08177300 & $1 / 11 / 2010$ & 469 & 253 & 81.2 & 12.1 & 3.13 & 1.30 & 47.3 & 221 \\
\hline 08177300 & $6 / 21 / 2010$ & 636 & 310 & 92.0 & 19.2 & 3.34 & 2.32 & 93.7 & 201 \\
\hline 284528097095400 & $1 / 14 / 2010$ & -- & -- & -- & -- & -- & -- & -- & -- \\
\hline 284535097095101 & 8/7/2009 & 541 & 358 & 120 & 14.0 & 2.15 & 1.13 & 49.2 & 329 \\
\hline 284535097095101 & $1 / 14 / 2010$ & 518 & 321 & 109 & 11.5 & 1.79 & .93 & 38.1 & 322 \\
\hline 284535097095101 & $6 / 21 / 2010$ & 457 & 347 & 119 & 12.1 & 1.76 & .94 & 40.4 & -- \\
\hline 285025097182101 & $8 / 6 / 2009$ & 665 & 296 & 88.7 & 17.7 & 3.26 & 2.86 & 113 & 248 \\
\hline 285025097182101 & $1 / 14 / 2010$ & 677 & 288 & 86.0 & 17.5 & 3.27 & 2.78 & 108 & 254 \\
\hline 285025097182101 & $6 / 22 / 2010$ & 689 & 310 & 93.0 & 18.6 & 3.51 & 2.98 & 120 & 254 \\
\hline 285049097111201 & 8/7/2009 & 726 & 394 & 132 & 15.7 & 2.85 & 1.75 & 79.9 & 286 \\
\hline 285134097130601 & $8 / 6 / 2009$ & 608 & 162 & -- & -- & -- & -- & -- & 258 \\
\hline 285134097130601 & $1 / 14 / 2010$ & 607 & 260 & 81.4 & 13.5 & 3.34 & 2.74 & 101 & 262 \\
\hline 285345097215201 & $6 / 22 / 2010$ & 585 & 315 & 98.1 & 16.8 & 3.21 & 2.15 & 87.8 & 292 \\
\hline 285354097215401 & $8 / 5 / 2009$ & 846 & 401 & 128 & 19.2 & 2.23 & 2.70 & 124 & 345 \\
\hline 285354097215401 & $1 / 13 / 2010$ & 814 & 367 & 118 & 17.3 & 2.45 & 2.62 & 115 & 329 \\
\hline 285354097215401 & $6 / 22 / 2010$ & 743 & 377 & 122 & 17.7 & 2.36 & 2.60 & 116 & 324 \\
\hline 285443097174801 & $8 / 6 / 2009$ & 501 & 263 & 90.3 & 8.94 & 2.43 & 1.78 & 66.3 & 273 \\
\hline 285443097174801 & $1 / 12 / 2010$ & 519 & 252 & 86.3 & 8.83 & 2.39 & 1.71 & 62.4 & 291 \\
\hline 285443097174801 & $6 / 23 / 2010$ & 503 & 282 & 97.1 & 9.47 & 2.60 & 1.81 & 69.7 & 292 \\
\hline 285445097215301 & $8 / 5 / 2009$ & 493 & 253 & 83.8 & 10.4 & 3.51 & 2.08 & 76.0 & 267 \\
\hline 285616097222801 & $8 / 5 / 2009$ & 586 & 285 & 92.8 & 12.9 & 4.22 & 2.23 & 86.6 & 260 \\
\hline 285616097222801 & $1 / 12 / 2010$ & 610 & 264 & 85.5 & 12.1 & 4.17 & 2.19 & 81.8 & 267 \\
\hline 285616097222801 & $6 / 23 / 2010$ & 587 & 299 & 97.1 & 13.5 & 4.60 & 2.32 & 91.9 & 268 \\
\hline 285658097290101 & $8 / 4 / 2009$ & 851 & 367 & 123 & 14.5 & 4.13 & 3.47 & 153 & 313 \\
\hline 285658097290101 & $1 / 12 / 2010$ & 871 & 361 & 120 & 14.4 & 4.32 & 3.55 & 155 & 320 \\
\hline 285658097290101 & $6 / 23 / 2010$ & 850 & 385 & 129 & 15.0 & 4.40 & 3.58 & 161 & 326 \\
\hline 285750097224001 & 8/4/2009 & 474 & 229 & 77.9 & 8.18 & 2.40 & 2.13 & 73.8 & 278 \\
\hline
\end{tabular}


Table 7. Water-quality data collected from surface-water, groundwater, and spring sites, upper Coleto Creek watershed, southeast Texas, August 2009-June 2010.-Continued

[USGS, U.S. Geological Survey; --, no data or not applicable; <, less than; E, estimated; ${ }^{\circ} \mathrm{C}$, degrees Celsius; mg/L, milligrams per liter; $\mu \mathrm{g} / \mathrm{L}$, micrograms per liter]

\begin{tabular}{|c|c|c|c|c|c|c|c|c|c|c|}
\hline Station number & Date & $\begin{array}{c}\text { Bicarbonate, } \\
\text { water, } \\
\text { filtered } \\
(\mathrm{mg} / \mathrm{L})\end{array}$ & $\begin{array}{c}\text { Bromide, } \\
\text { water, } \\
\text { filtered } \\
(\mathrm{mg} / \mathrm{L})\end{array}$ & $\begin{array}{c}\text { Carbon } \\
\text { dioxide, } \\
\text { water, } \\
\text { unfiltered } \\
\text { (mg/L) }\end{array}$ & $\begin{array}{c}\text { Carbonate, } \\
\text { water, } \\
\text { filtered, } \\
\text { field } \\
\text { (mg/L) }\end{array}$ & $\begin{array}{c}\text { Chloride, } \\
\text { water, } \\
\text { filtered } \\
\text { (mg/L) }\end{array}$ & $\begin{array}{c}\text { Fluoride, } \\
\text { water, } \\
\text { filtered } \\
\text { (mg/L) }\end{array}$ & $\begin{array}{c}\text { Silica, } \\
\text { water, } \\
\text { filtered } \\
(\mathrm{mg} / \mathrm{L} \text { as } \\
\left.\mathrm{SiO}_{2}\right)\end{array}$ & $\begin{array}{c}\text { Sulfate, } \\
\text { water, } \\
\text { filtered } \\
(\mathrm{mg} / \mathrm{L})\end{array}$ & $\begin{array}{c}\text { Ammonia, } \\
\text { water, } \\
\text { filtered } \\
(\mathrm{mg} / \mathrm{L} \text { as } \\
\left.\mathrm{NH}_{4}\right)\end{array}$ \\
\hline 08176540 & $1 / 12 / 2010$ & 331 & 0.56 & 6.8 & 1 & 170 & 0.27 & 26.5 & 54.9 & 0.092 \\
\hline 08176540 & $6 / 23 / 2010$ & 345 & .73 & 7.7 & 2 & 218 & .43 & 34.0 & 53.3 & .141 \\
\hline 08176590 & $1 / 13 / 2010$ & 329 & .42 & 4.9 & $<1$ & 117 & .31 & 23.6 & 36.4 & $<.026$ \\
\hline 08176900 & $1 / 14 / 2010$ & 293 & .36 & 3.4 & 2 & 98.7 & .28 & 20.8 & 31.7 & $<.026$ \\
\hline 08176900 & $6 / 24 / 2010$ & 309 & .52 & 5.9 & 2 & 139 & .39 & 38.0 & 28.6 & E. .023 \\
\hline 08177300 & $1 / 11 / 2010$ & 268 & .37 & 7.5 & $<1$ & 100 & .31 & 20.8 & 26.4 & $<.026$ \\
\hline 08177300 & $6 / 21 / 2010$ & 245 & .78 & 5.1 & $<1$ & 196 & .53 & 48.8 & 29.0 & E.023 \\
\hline 284528097095400 & $1 / 14 / 2010$ & -- & -- & -- & -- & -- & -- & -- & -- & -- \\
\hline 284518097185401 & $6 / 24 / 2010$ & 336 & .17 & E 46 & $<1$ & 56.5 & .70 & 48.1 & 18.1 & $<.026$ \\
\hline 284535097095101 & $8 / 7 / 2009$ & 400 & .42 & Е 289 & $<1$ & 81.5 & .24 & 38.5 & 14.8 & $<.026$ \\
\hline 284535097095101 & $1 / 14 / 2010$ & 393 & .43 & E 80 & $<1$ & 77.2 & .22 & 33.4 & 6.73 & $<.026$ \\
\hline 284535097095101 & $6 / 21 / 2010$ & -- & .40 & -- & -- & 73.8 & .25 & 35.4 & 5.98 & $<.026$ \\
\hline 285025097182101 & $8 / 6 / 2009$ & 302 & .57 & E 251 & $<1$ & 190 & .51 & 32.6 & 39.8 & $<.026$ \\
\hline 285025097182101 & $1 / 14 / 2010$ & 309 & .56 & E 38 & $<1$ & 194 & .51 & 30.2 & 39.8 & $<.026$ \\
\hline 285025097182101 & $6 / 22 / 2010$ & 309 & .54 & E 46 & $<1$ & 193 & .56 & 32.6 & 37.3 & $<.026$ \\
\hline 285049097111201 & $8 / 7 / 2009$ & 348 & .78 & E 252 & $<1$ & 192 & .22 & 37.3 & 22.9 & $<.026$ \\
\hline 285134097130601 & $8 / 6 / 2009$ & 314 & .53 & 157 & $<1$ & 167 & .37 & 15.6 & 26.9 & $<.026$ \\
\hline 285134097130601 & $1 / 14 / 2010$ & 319 & .48 & 37 & $<1$ & 168 & .41 & 26.7 & 26.8 & $<.026$ \\
\hline 285345097215201 & $6 / 22 / 2010$ & E 356 & .38 & 42 & $<1$ & 123 & .72 & 42.4 & 36.2 & $<.026$ \\
\hline 285354097215401 & $8 / 5 / 2009$ & 420 & .80 & E 271 & $<1$ & 200 & .72 & 58.6 & 48.0 & $<.026$ \\
\hline 285354097215401 & $1 / 13 / 2010$ & 401 & .76 & 68 & $<1$ & 195 & .69 & 53.3 & 47.0 & $<.026$ \\
\hline 285354097215401 & $6 / 22 / 2010$ & 395 & .63 & 39 & $<1$ & 165 & .73 & 53.5 & 47.1 & $<.026$ \\
\hline 285443097174801 & $8 / 6 / 2009$ & 332 & .29 & E 458 & $<1$ & 90.4 & .31 & 44.8 & 18.5 & $<.026$ \\
\hline 285443097174801 & $1 / 12 / 2010$ & 354 & .28 & E 53 & $<1$ & 90.6 & .31 & 40.6 & 17.9 & $<.026$ \\
\hline 285443097174801 & $6 / 23 / 2010$ & E 355 & .27 & E 58 & $<1$ & 89.2 & .33 & 44.7 & 16.3 & $<.026$ \\
\hline 285445097215301 & $8 / 5 / 2009$ & 325 & .30 & E 187 & $<1$ & 90.9 & .48 & 38.0 & 21.3 & $<.026$ \\
\hline 285616097222801 & $8 / 5 / 2009$ & 317 & .49 & E 96 & $<1$ & 133 & .53 & 43.8 & 27.8 & $<.026$ \\
\hline 285616097222801 & $1 / 12 / 2010$ & 325 & .49 & E 39 & $<1$ & 138 & .54 & 44.6 & 27.8 & $<.026$ \\
\hline 285616097222801 & $6 / 23 / 2010$ & 326 & .46 & E 49 & $<1$ & 132 & .57 & 44.6 & 26.0 & $<.026$ \\
\hline 285658097290101 & $8 / 4 / 2009$ & 381 & .74 & Е 289 & $<1$ & 259 & .42 & 36.6 & 35.8 & $<.026$ \\
\hline 285658097290101 & $1 / 12 / 2010$ & 390 & .74 & E 79 & $<1$ & 271 & .41 & 34.0 & 35.8 & $<.026$ \\
\hline 285658097290101 & $6 / 23 / 2010$ & 397 & .69 & E 91 & $<1$ & 269 & .47 & 36.2 & 33.7 & $<.026$ \\
\hline 285750097224001 & $8 / 4 / 2009$ & 339 & .28 & Е 269 & $<1$ & 81.8 & .41 & 39.2 & 22.0 & $<.026$ \\
\hline
\end{tabular}


Table 7. Water-quality data collected from surface-water, groundwater, and spring sites, upper Coleto Creek watershed, southeast Texas, August 2009-June 2010.-Continued

[USGS, U.S. Geological Survey; --, no data or not applicable; <, less than; E, estimated; ${ }^{\circ} \mathrm{C}$, degrees Celsius; mg/L, milligrams per liter; $\mu \mathrm{g} / \mathrm{L}$, micrograms per liter]

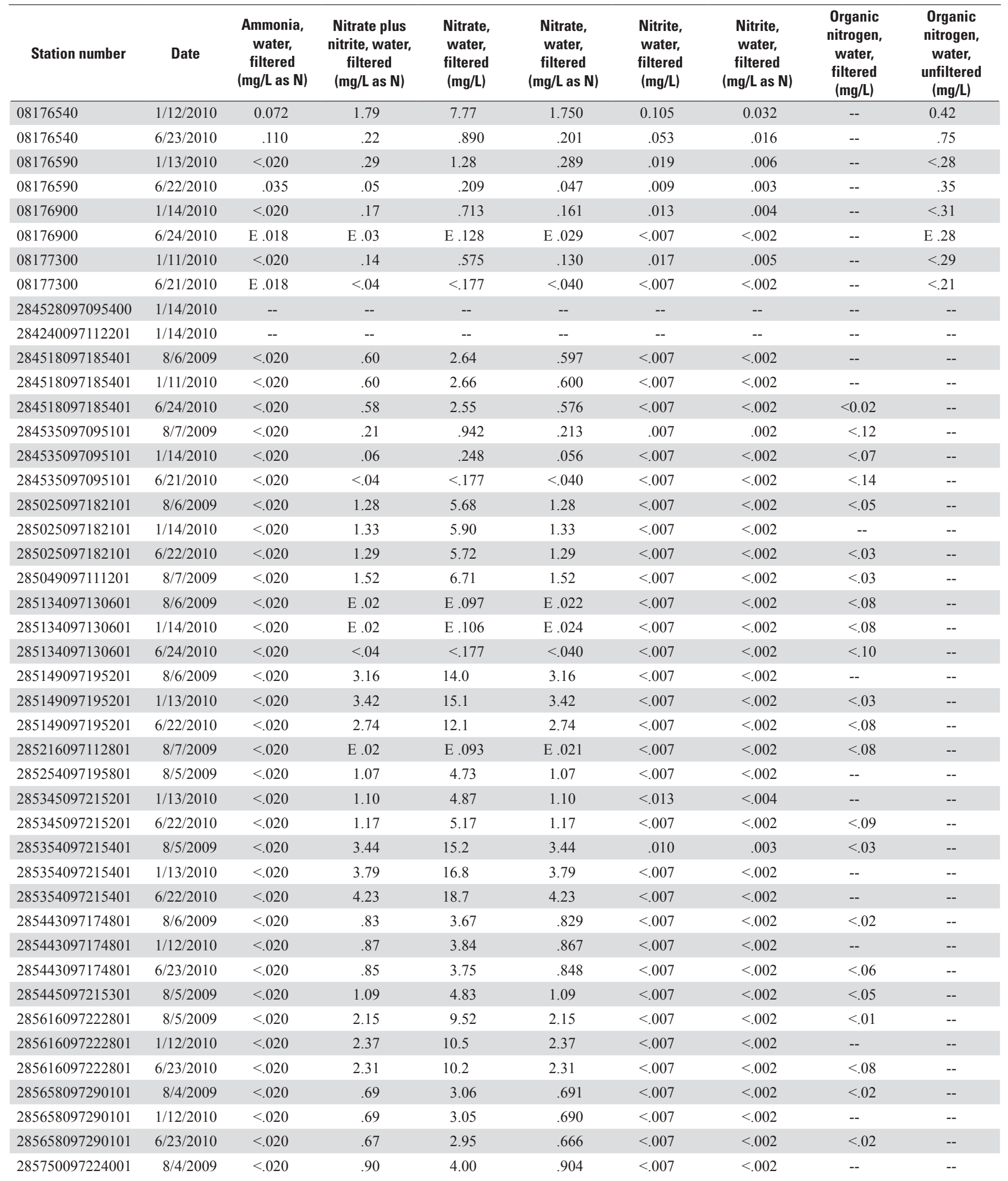


Table 7. Water-quality data collected from surface-water, groundwater, and spring sites, upper Coleto Creek watershed, southeast Texas, August 2009-June 2010.-Continued

[USGS, U.S. Geological Survey; --, no data or not applicable; <, less than; E, estimated; ${ }^{\circ} \mathrm{C}$, degrees Celsius; mg $/ \mathrm{L}$, milligrams per liter; $\mu \mathrm{g} / \mathrm{L}$, micrograms per liter]

\begin{tabular}{|c|c|c|c|c|c|c|c|}
\hline Station number & Date & $\begin{array}{l}\text { Orthophosphate, } \\
\text { water, } \\
\text { filtered } \\
(\mathrm{mg} / \mathrm{L})\end{array}$ & $\begin{array}{c}\text { Orthophosphate, } \\
\text { water, } \\
\text { filtered } \\
\text { (mg/L as P) }\end{array}$ & $\begin{array}{l}\text { Phosphorus, } \\
\text { water, } \\
\text { unfiltered } \\
(\mathrm{mg} / \mathrm{L} \text { as } \mathrm{P})\end{array}$ & $\begin{array}{c}\text { Total nitrogen (nitrate } \\
\text { + nitrite + ammonia + } \\
\text { organic-N), water, } \\
\text { filtered } \\
\text { (mg/L) }\end{array}$ & $\begin{array}{c}\text { Total nitrogen } \\
\text { (nitrate + nitrite + } \\
\text { ammonia + organic-N), } \\
\text { water, unfiltered } \\
\text { (mg/L) }\end{array}$ & $\begin{array}{c}\text { Aluminum, } \\
\text { water, } \\
\text { filtered } \\
(\mu \mathrm{g} / \mathrm{L})\end{array}$ \\
\hline 08176540 & $1 / 12 / 2010$ & 1.94 & 0.632 & 0.682 & -- & 2.28 & 13.3 \\
\hline 08176540 & $6 / 23 / 2010$ & 2.15 & .701 & .725 & -- & 1.08 & E 3.0 \\
\hline 08176590 & $1 / 13 / 2010$ & .131 & .043 & .058 & -- & .58 & 21.0 \\
\hline 08176900 & $6 / 24 / 2010$ & .247 & .081 & .079 & -- & .33 & E 2.1 \\
\hline 08177300 & $1 / 11 / 2010$ & .028 & .009 & .009 & -- & .42 & 7.8 \\
\hline 08177300 & $6 / 21 / 2010$ & .088 & .029 & E. .007 & -- & .23 & 7.8 \\
\hline 284528097095400 & $1 / 14 / 2010$ & -- & -- & -- & -- & -- & -- \\
\hline 284535097095101 & 8/7/2009 & .172 & .056 & -- & .34 & -- & $<4.0$ \\
\hline 284535097095101 & $1 / 14 / 2010$ & .200 & .065 & -- & .12 & -- & $<3.4$ \\
\hline 284535097095101 & $6 / 21 / 2010$ & .225 & .074 & -- & .14 & -- & E 2.7 \\
\hline 285025097182101 & $8 / 6 / 2009$ & .049 & .016 & -- & 1.33 & -- & $<4.0$ \\
\hline 285025097182101 & $1 / 14 / 2010$ & .052 & .017 & -- & 1.22 & -- & $<10.2$ \\
\hline 285025097182101 & $6 / 22 / 2010$ & .082 & .027 & -- & 1.33 & -- & $<3.4$ \\
\hline 285049097111201 & 8/7/2009 & .060 & .020 & -- & 1.55 & -- & $<4.0$ \\
\hline 285134097130601 & $8 / 6 / 2009$ & .045 & .015 & -- & $<.10$ & -- & 8.5 \\
\hline 285134097130601 & $1 / 14 / 2010$ & .047 & .015 & -- & $<.10$ & -- & 4.0 \\
\hline 285345097215201 & $6 / 22 / 2010$ & .086 & .028 & -- & 1.26 & -- & $<3.4$ \\
\hline 285354097215401 & $8 / 5 / 2009$ & .086 & .028 & -- & 3.48 & -- & $<4.0$ \\
\hline 285354097215401 & $1 / 13 / 2010$ & .067 & .022 & .012 & -- & 3.71 & $<10.2$ \\
\hline 285354097215401 & $6 / 22 / 2010$ & .126 & .041 & .011 & -- & 4.17 & E 2.8 \\
\hline 285443097174801 & 8/6/2009 & .067 & .022 & -- & .85 & -- & $<4.0$ \\
\hline 285443097174801 & $1 / 12 / 2010$ & .076 & .025 & -- & .77 & -- & $<3.4$ \\
\hline 285443097174801 & $6 / 23 / 2010$ & .111 & .036 & -- & .90 & -- & $<3.4$ \\
\hline 285445097215301 & $8 / 5 / 2009$ & .059 & .019 & -- & 1.14 & -- & $<4.0$ \\
\hline 285616097222801 & $8 / 5 / 2009$ & .064 & .021 & -- & 2.16 & -- & E 2.4 \\
\hline 285616097222801 & $1 / 12 / 2010$ & .065 & .021 & -- & 2.17 & -- & 7.9 \\
\hline 285616097222801 & $6 / 23 / 2010$ & .093 & .030 & -- & 2.39 & -- & 3.7 \\
\hline 285658097290101 & $8 / 4 / 2009$ & .058 & .019 & -- & .71 & -- & $<4.0$ \\
\hline 285658097290101 & $1 / 12 / 2010$ & .059 & .019 & -- & .61 & -- & $<10.2$ \\
\hline 285658097290101 & $6 / 23 / 2010$ & .081 & .027 & -- & .69 & -- & $<3.4$ \\
\hline 285750097224001 & $8 / 4 / 2009$ & .060 & .020 & -- & .90 & -- & $<4.0$ \\
\hline
\end{tabular}


Table 7. Water-quality data collected from surface-water, groundwater, and spring sites, upper Coleto Creek watershed, southeast Texas, August 2009-June 2010.-Continued

[USGS, U.S. Geological Survey; --, no data or not applicable; <, less than; E, estimated; ${ }^{\circ} \mathrm{C}$, degrees Celsius; mg/L, milligrams per liter; $\mu \mathrm{g} / \mathrm{L}$, micrograms per liter]

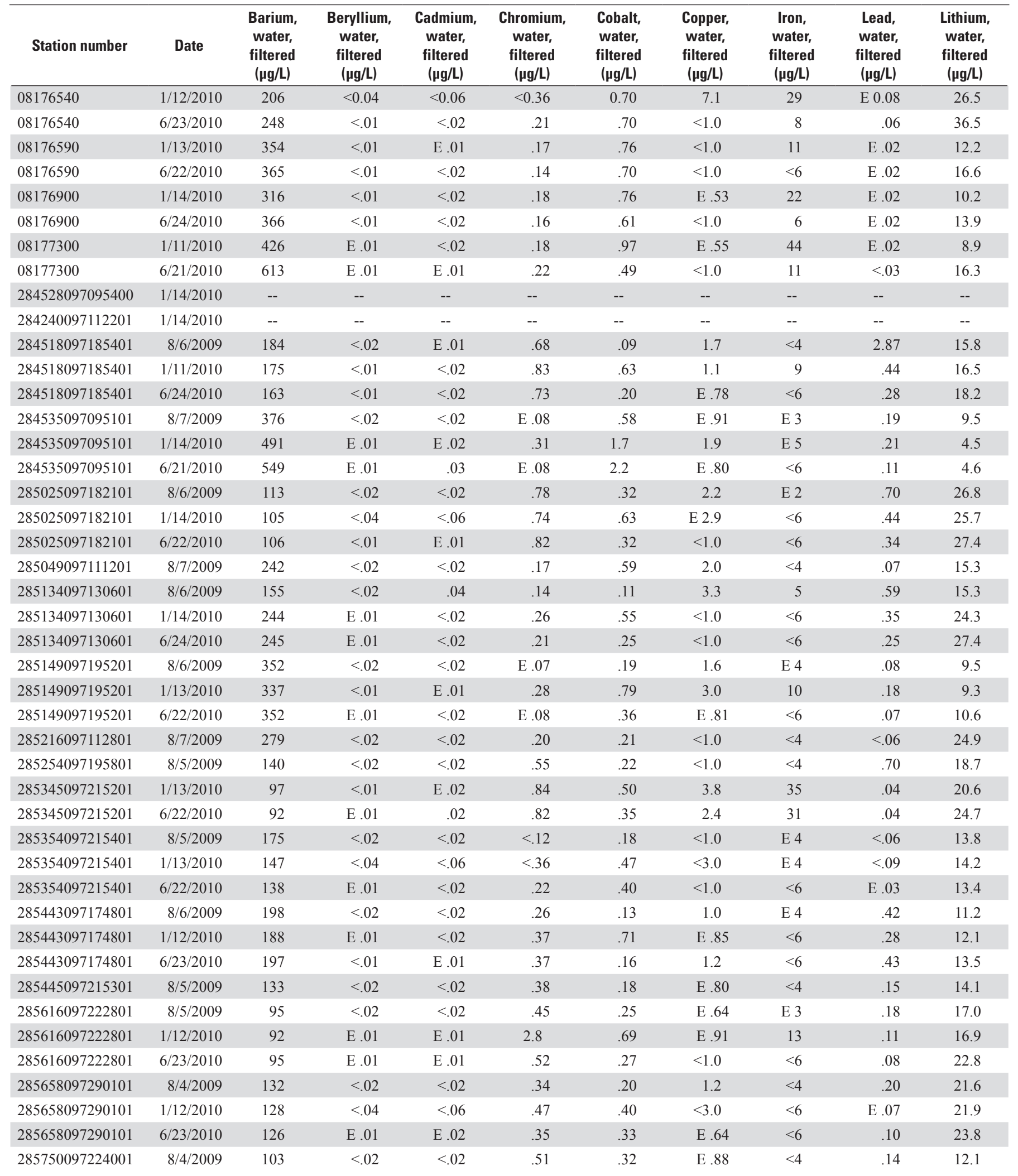


Table 7. Water-quality data collected from surface-water, groundwater, and spring sites, upper Coleto Creek watershed, southeast Texas, August 2009-June 2010.-Continued

[USGS, U.S. Geological Survey; --, no data or not applicable; <, less than; E, estimated; ${ }^{\circ} \mathrm{C}$, degrees Celsius; $\mathrm{mg} / \mathrm{L}$, milligrams per liter; $\mu \mathrm{g} / \mathrm{L}$, micrograms per liter]

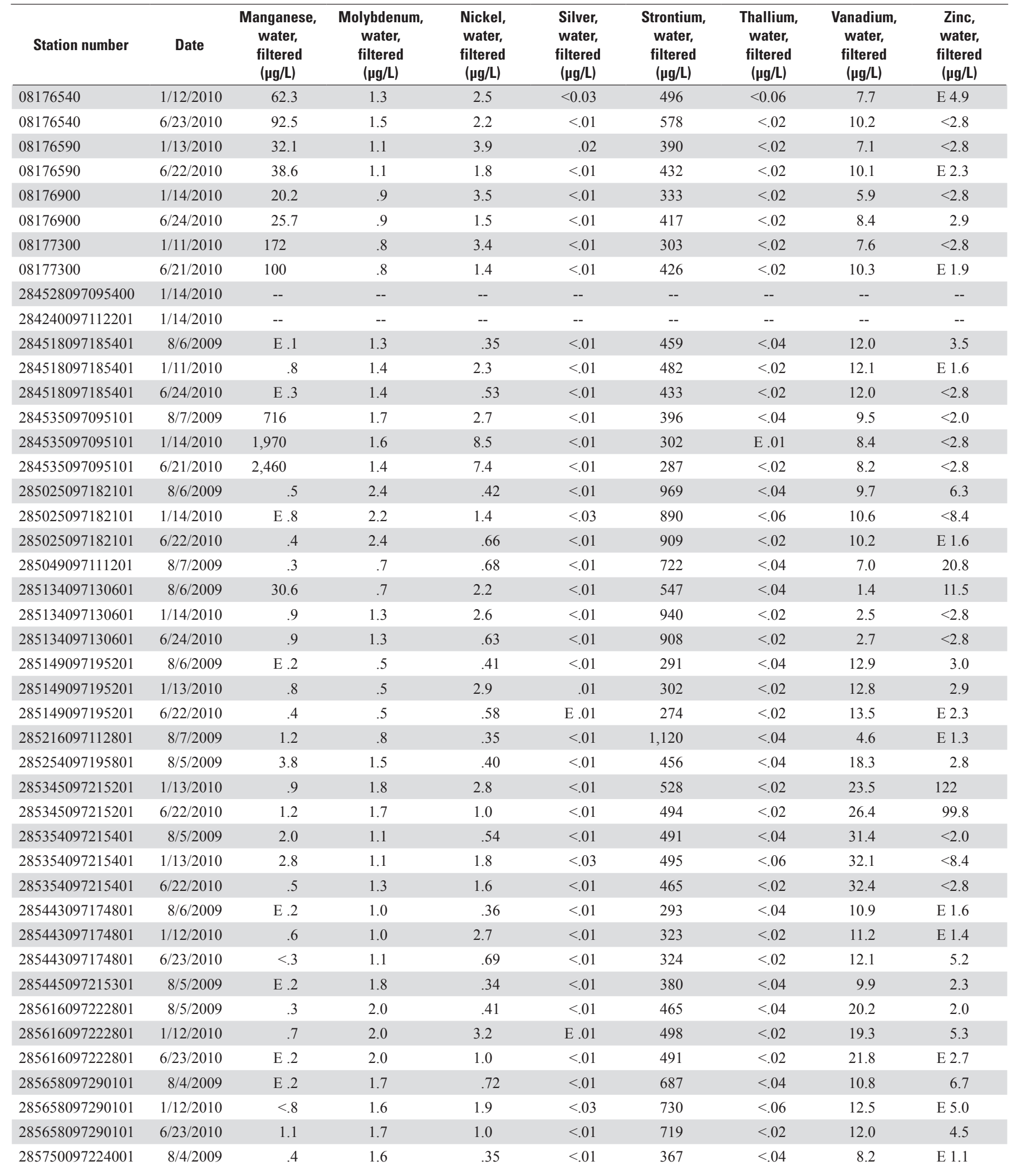


Table 7. Water-quality data collected from surface-water, groundwater, and spring sites, upper Coleto Creek watershed, southeast Texas, August 2009-June 2010.-Continued

[USGS, U.S. Geological Survey; --, no data or not applicable; <, less than; E, estimated; ${ }^{\circ} \mathrm{C}$, degrees Celsius; mg/L, milligrams per liter; $\mu \mathrm{g} / \mathrm{L}$, micrograms per liter]

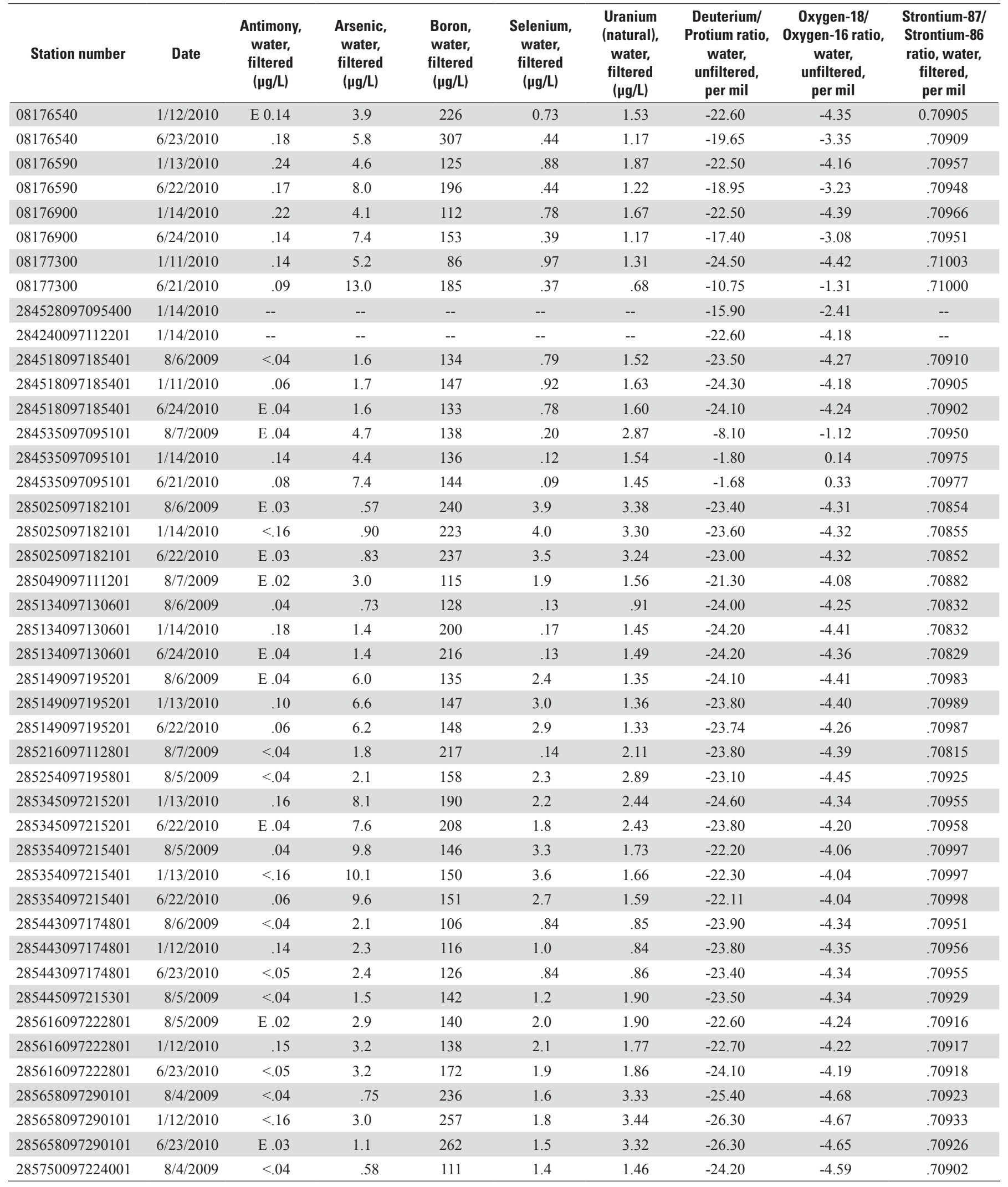




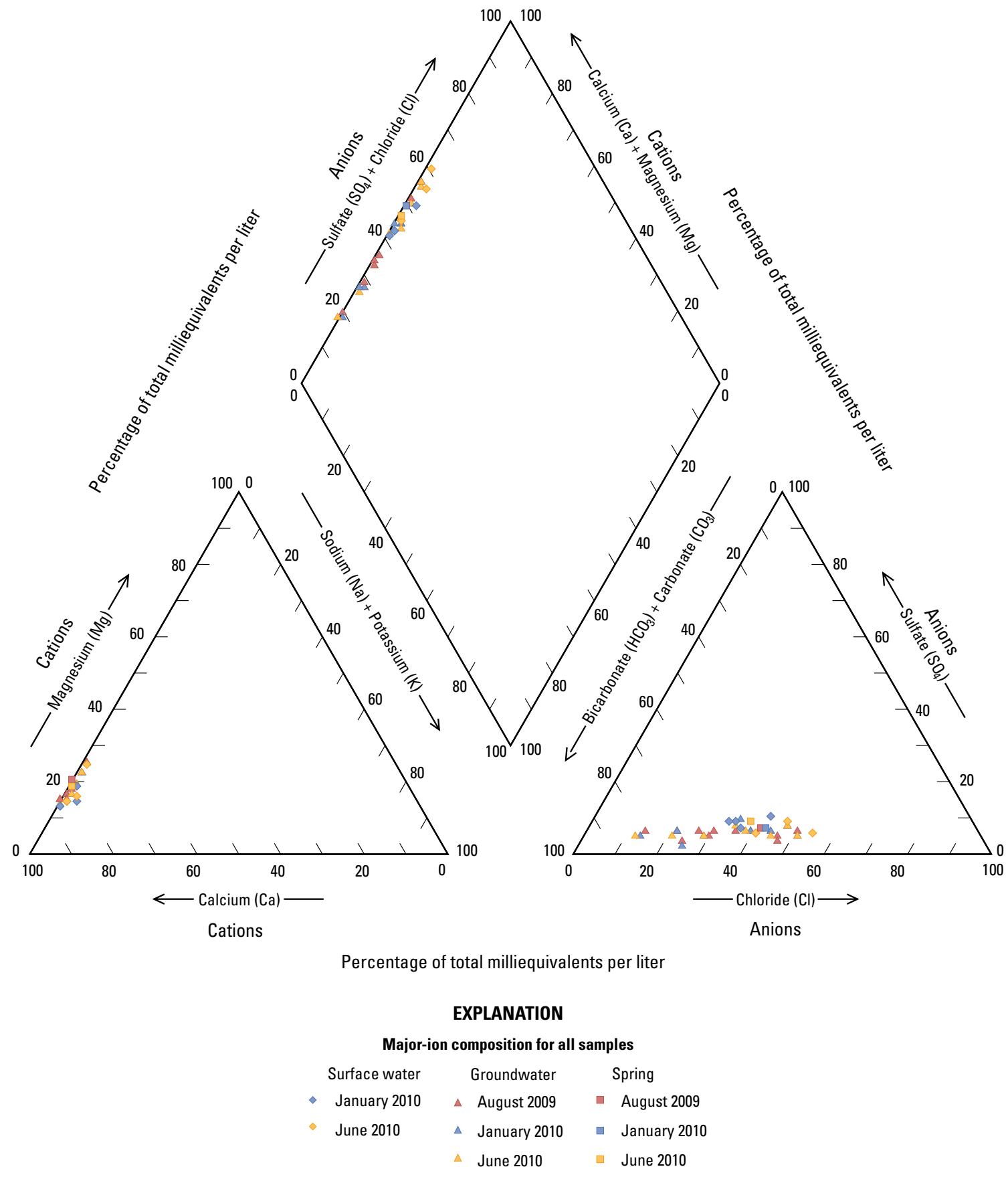

Figure 11. Trilinear diagrams showing composition of surface water, groundwater, and spring water in the upper Coleto Creek watershed, southeast Texas, August 2009, January 2010, and June 2010. 

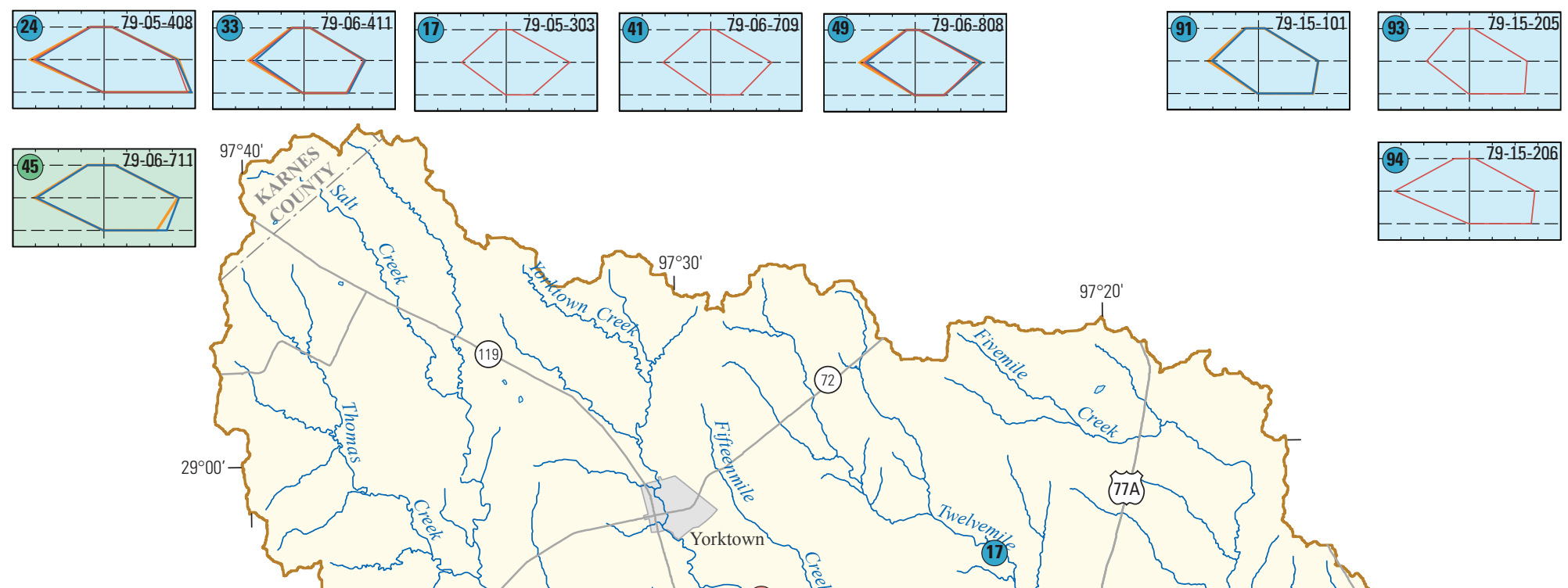

Base modified from U.S. Geological Survey

1:24,000 quadrangle digital data
Universal Transverse Mercator projection, Zone 14 North American Datum of 1983 (NAD 83)
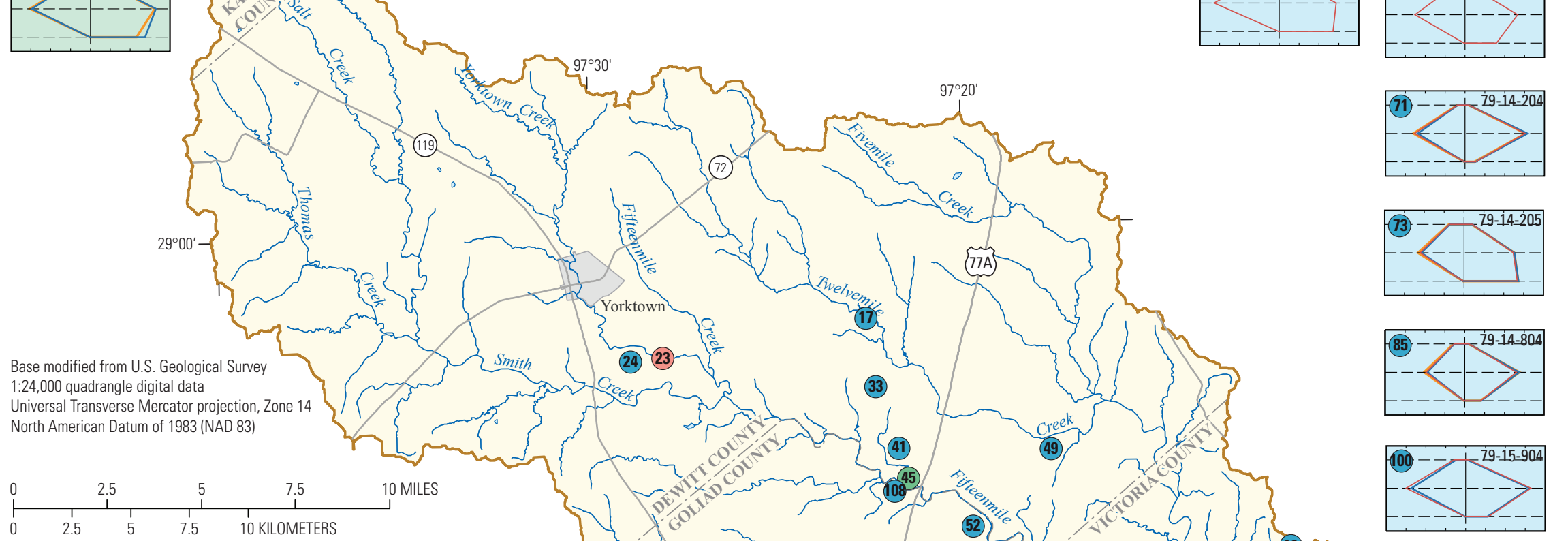

\section{EXPLANATION}

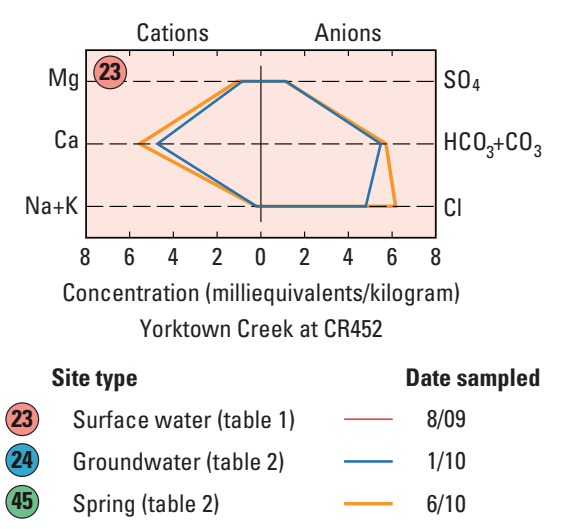

Figure 12. Stiff diagrams showing composition of surface water, groundwater, and spring water in the upper Coleto Creek watershed, southeast Texas, August 2009, January 2010, and June 2010.

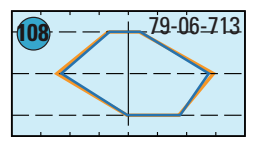

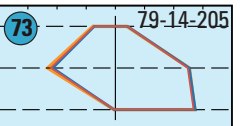
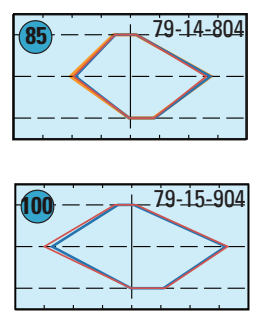

Perdido Creek at FM 622 


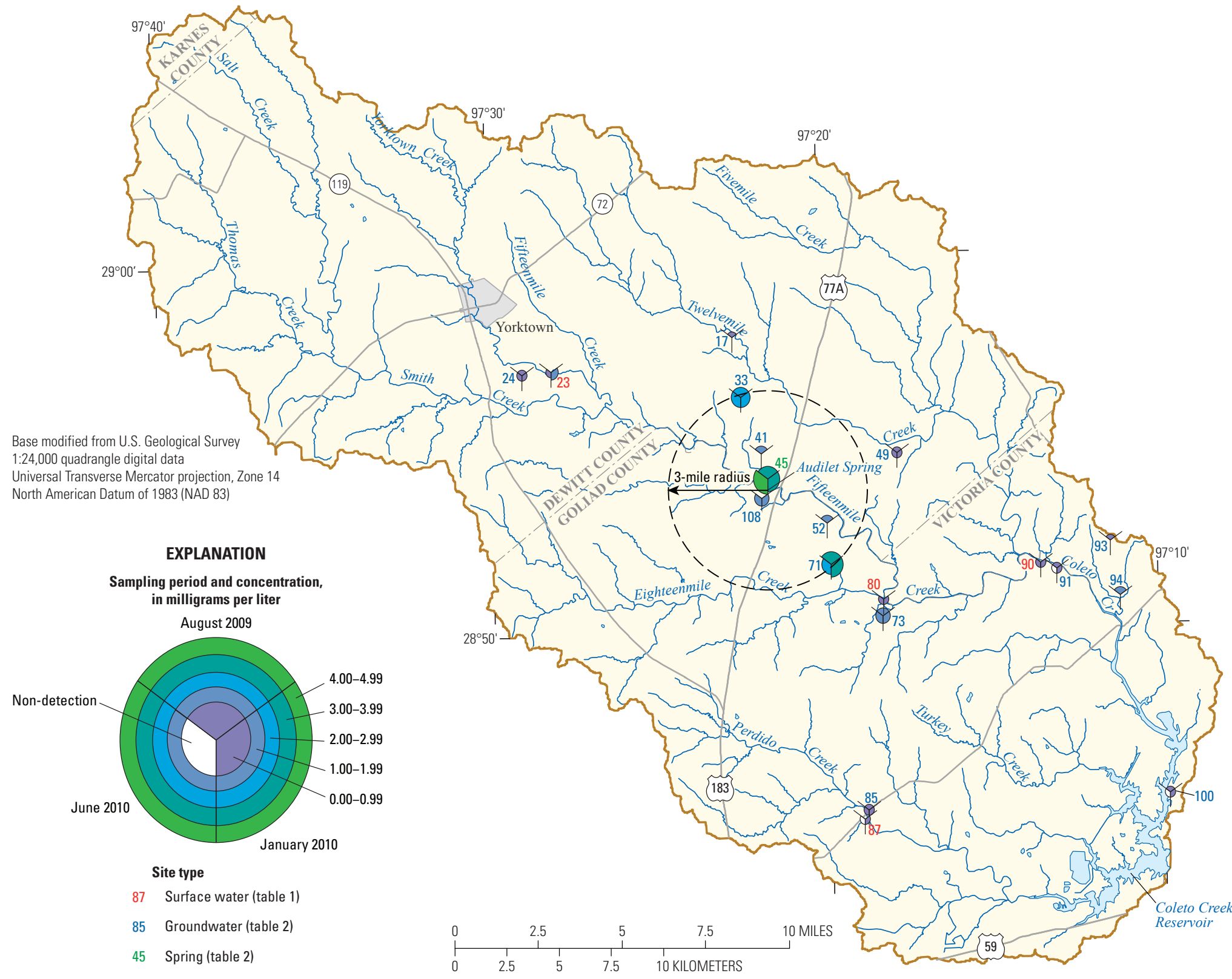

Figure 13. Nitrate concentrations (as nitrogen) in surface water, groundwater, and spring water in the upper Coleto Creek watershed, southeast Texas, August 2009, January 2010, and June 2010. 


\section{Isotopes}

Hydrogen and oxygen isotopes of water can be used to assess groundwater sources and recharge processes, thereby enhancing the knowledge of processes related to water quality. In the absence of thermal effects, evaporation and mixing are the primary processes that affect the isotopic composition of groundwater (Clark and Fritz, 1997). Figure 14 shows the relation of the ratio of oxygen-18 to oxygen-16 $\left(\delta^{18} \mathrm{O}\right.$, in per mil) to the ratio of deuterium to protium $(\delta \mathrm{D}$, in per mil) in samples collected for this study, relative to Vienna Standard Mean Ocean Water (VSMOW) isotopic standard (Baertschi, 1976; Hagemann and others, 1970).

The consistent proportionality between $\delta \mathrm{D}$ and $\delta^{18} \mathrm{O}$ in meteoric waters provides the basis for many hydrologic applications and is defined by a best-fit regression line known as the global meteoric water line (Craig, 1961) expressed by the equation

$$
\delta \mathrm{D}=8 \delta^{18} \mathrm{O}+10
$$

where

$\delta \mathrm{D} \quad$ is the ratio of hydrogen-2 to hydrogen-1
isotopes reported as the relative difference
in parts per thousand (per mil) between the
sample isotope ratio and the isotope ratio
of a known standard, and
$\delta^{18} \mathrm{O} \quad$ is the ratio of oxygen-18 to oxygen-16
isotopes reported as the relative difference
in parts per thousand (per mil) between the
sample isotope ratio and the isotope ratio
of a known standard.

A local meteoric water line (LMWL) was developed by Otero (2007) using isotopic signatures from south-central Texas precipitation data. All of the samples collected during this study plotted below the LMWL of $\delta \mathrm{D}=8.8032 \delta^{18} \mathrm{O}$ +17.825 , which indicates that the lighter water molecules associated with precipitation might have been preferentially removed as a result of evapotranspiration before they could enter the aquifer as recharge.

The majority of the water samples (36 out of 44 ) that were analyzed for $\delta \mathrm{D}$ and $\delta^{18} \mathrm{O}$ during the three sampling events plotted in a relatively tight cluster centered near the global meteoric water line (fig. 14); this finding indicates that these sites are most likely not heavily influenced by evaporative processes. The eight remaining samples, which include the four surface-water samples collected in June 2010, the sample collected from Coleto Creek Reservoir site in January 2010, and all three samples collected at State well 79-15-904 (site 100), deviate from the global meteoric water line in a way that indicates evaporative losses, with the largest losses occurring at station 08177300 on Perdido Creek. The surface-water samples collected from those same four locations in January 2010 did not exhibit signs of evaporative losses; rather, they exhibited an isotopic signature more closely related to that which was observed in the wells (other than State well 79-15-904). Isotopic signatures indicative of evaporative losses were also measured in the sample collected at the Coleto Creek Reservoir site and in the three samples collected from State well 79-15-904. As a surface-water body, this response is expected for the samples collected from Coleto Creek Reservoir site, but this type of response is atypical of wells in this area (as evidenced by the isotopic signatures observed at the remaining wells sampled in this study). The isotopic signatures of the three samples collected at State well 79-15-904, when taken in conjunction with its proximity to Coleto Creek Reservoir, indicate that there is likely a hydraulic connection between the two. The fact that the isotopic signatures at State well 79-15-904 represent water that is even heavier isotopically than the reservoir itself might be due to the proximity (less than 1,000 ft) of 79-15-904 to two backwater areas where evaporative loss rates are likely much higher than that of Coleto Creek Reservoir as a whole. State well 79-23-205 (107 in the bottom frame of fig. 14) is also close to Coleto Creek Reservoir but has an isotopic signature that more closely resembles those of the remaining wells (other than State well 79-15-904). This relation indicates that the groundwater at State well 79-23-205 does not have a hydraulic connection to Coleto Creek Reservoir under the hydrologic conditions observed over the course of this study.

Strontium is a minor component of most groundwater and a divalent cation that readily substitutes for the divalent calcium ion $\left(\mathrm{Ca}^{2+}\right)$ in carbonates and other rock-forming minerals (Clark and Fritz, 1997). Strontium isotopes-specifically, the ratio of strontium- 87 to strontium- $86\left(\delta^{87} \mathrm{Sr}\right.$, per mil) — act as a reactive tracer that can be used to indicate water-rock interactions or to trace groundwater movement. In general, strontium concentrations were consistent in all samples collected at individual wells (with the exception of the samples from State wells 79-15-904 and 79-15-101 in August 2009, table 7). Individual surface-water sites also exhibited consistent chemistry with regards to $\delta^{87} \mathrm{Sr}$ but varied widely between January 2010 and June 2010 with respect to the inverse of strontium concentrations $(1 / \mathrm{Sr})$, which were higher in January 2010 than in June 2010 at all four sites (fig. 15). This means that strontium concentrations were higher in June 2010 than in January 2010, as would be expected considering that elevated streamflow in January 2010 relative to June 2010 was influenced to some extent by additional precipitation (fig $5 C$ ), which would likely have lower strontium concentrations. 


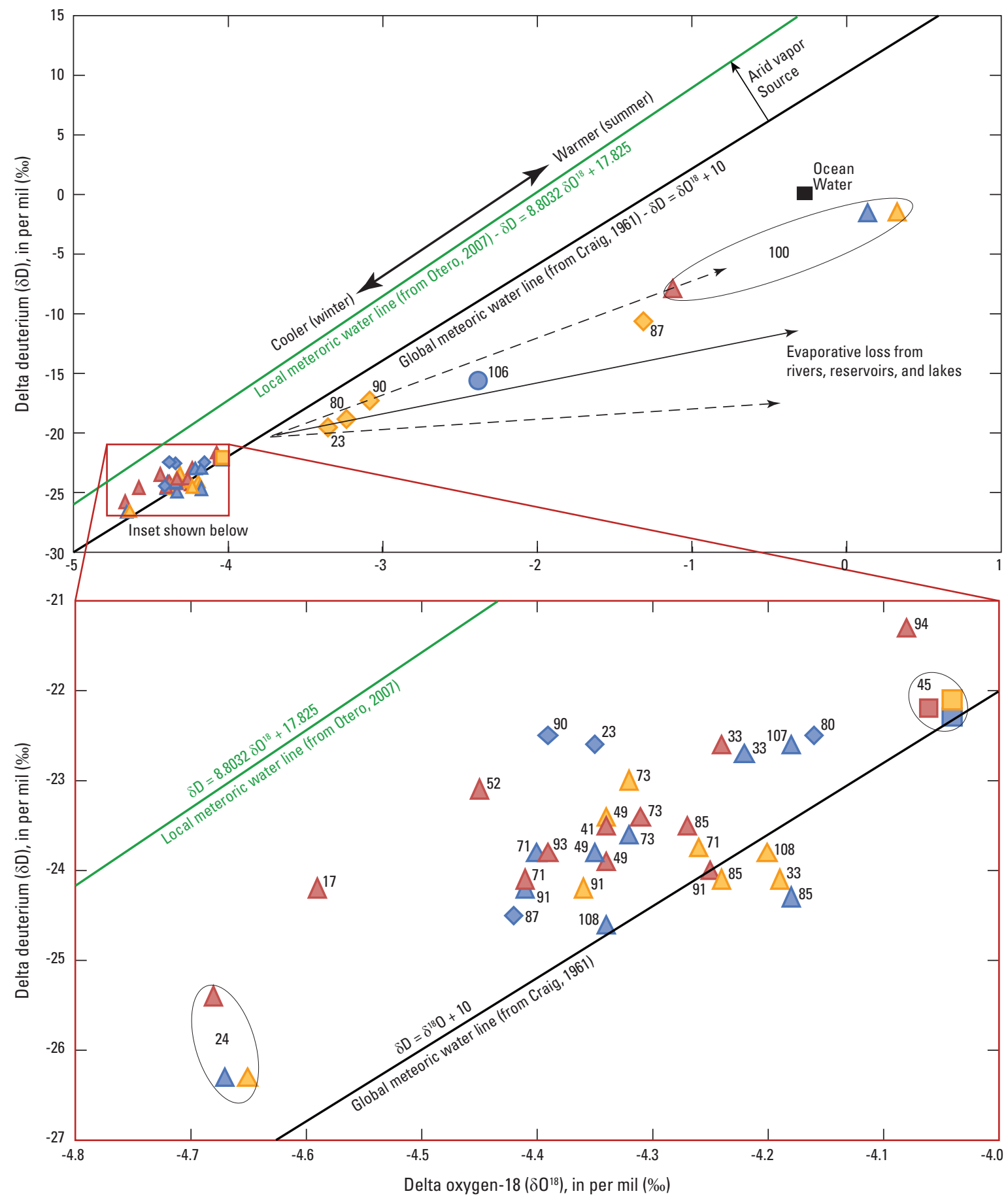

EXPLANATION

Site type, site number, and sampling period

\begin{tabular}{|c|c|c|c|}
\hline Surface water (table1) & Groundwater (table2) & Spring (table2) & Reservoir (table1) \\
\hline January 2010 & August 2009 & August 2009 & January 2010 \\
\hline June 2010 & January 2010 & January 2010 & \\
\hline & June 2010 & June 2010 & \\
\hline
\end{tabular}

Figure 14. Relation between delta oxygen-18 and delta deuterium in samples collected from selected surface-water, groundwater, and spring sites in the upper Coleto Creek watershed, southeast Texas, August 2009, January 2010, and June 2010. 


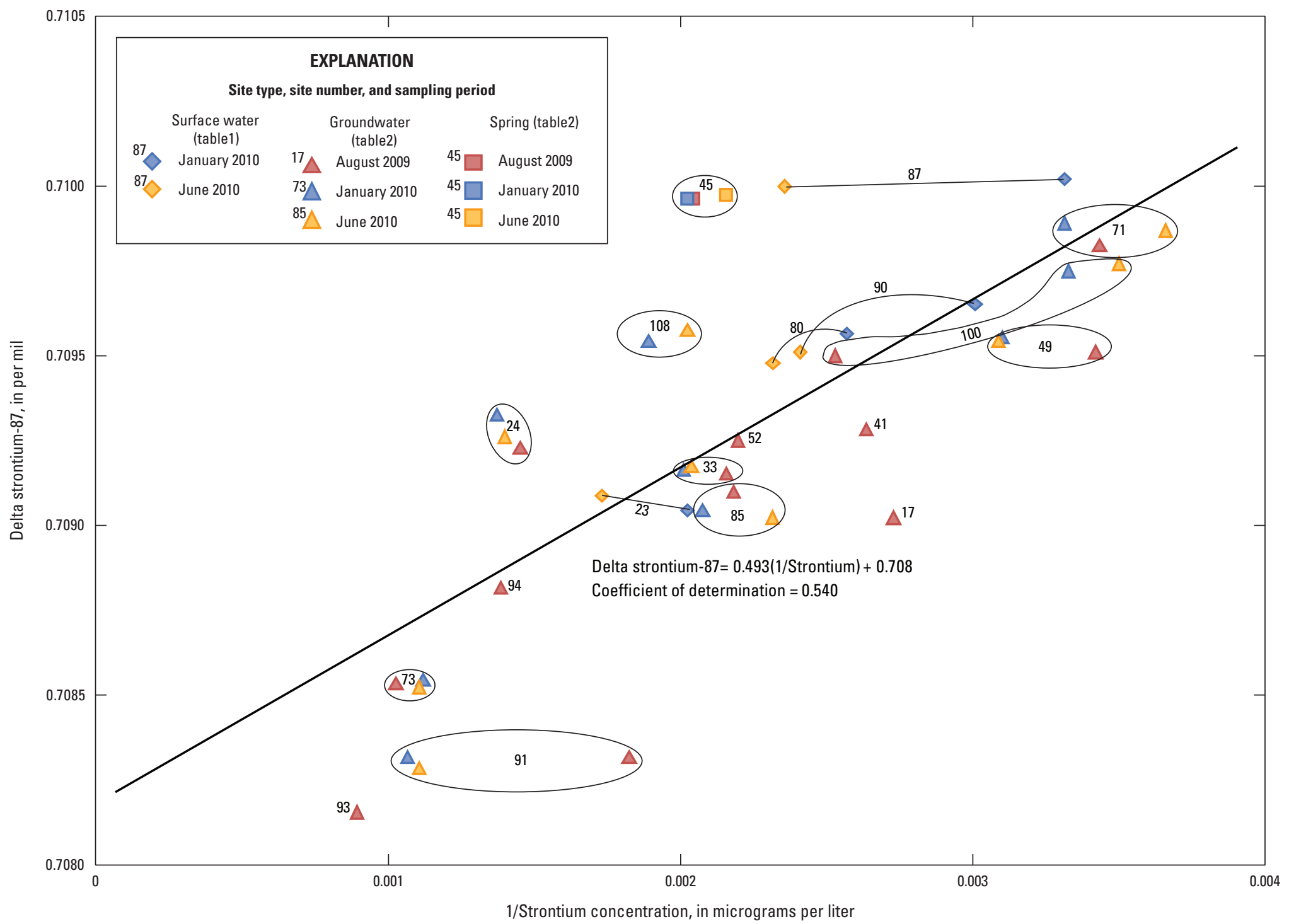

Figure 15. Relation between the inverse of strontium concentrations and delta strontium-87 in samples collected from surface-water, groundwater, and spring sites in the upper Coleto Creek watershed, southeast Texas, August 2009, January 2010, and June 2010. 
Examination of all the sites as a whole reveals a general pattern in strontium concentrations across the entire upper Coleto Creek watershed (fig. 15), as indicated by the best-fit regression line

$$
\delta^{87} \mathrm{Sr}=0.493 / \mathrm{Sr}+0.708
$$

where

$$
\begin{gathered}
8^{87} \mathrm{Sr} \text { is the ratio of strontium- } 87 \text { to strontium- } 86, \\
\text { and } \\
\mathrm{Sr} \text { is the concentration of strontium, in } \\
\text { micrograms per liter. }
\end{gathered}
$$

This pattern might indicate that most surface-water and groundwater samples derive primarily from a single source with relatively uniform water-rock interactions, the Evangeline aquifer. For samples collected from the following sites, one or more data values of the relation between the inverse of strontium concentration and $\delta^{87} \mathrm{Sr}$ differ appreciably from the bestfit regression line $\left(\delta^{87} \mathrm{~S}\right.$ values plot more than about 0.0003 per mil from the regression line) and thus do not closely fit the general pattern: site 17 (State well 79-05-303), site 24 (State well 79-05-408), site 45 (Audilet Spring), site 87 (station 08177300 on Perdido Creek ), and sites 91, 93, and 108 (State wells 79-15-101, 79-15-205, and 79-06-713, respectively). The reasons one or more of the samples collected from these sites do not closely fit the general pattern are not fully understood. The samples collected at these sites might represent a mix of water sources rather than water exclusively from the Evangeline aquifer, and the relative contributions from these different water sources might have varied by sampling period because each sampling period represented different hydrologic conditions.

\section{Summary}

The U.S. Geological Survey, in cooperation with the Goliad County Groundwater Conservation District, Victoria County Groundwater Conservation District, Pecan Valley Groundwater Conservation District, Guadalupe-Blanco River Authority, and San Antonio River Authority, examined streamflow, groundwater hydrology, and water quality in the upper Coleto Creek watershed. Findings of the study will enhance the scientific understanding of the study-area hydrology and be used to support water-management decisions in the study area. This report describes the results of streamflow measurements, groundwater-level altitude measurements, and water-quality analyses (from both surface water and groundwater sites) from three sampling events (July-August 2009, January 2010, and June 2010) designed to characterize groundwater (from the Evangeline aquifer) and surface water, and the interaction between them, in the upper Coleto Creek watershed upstream from Coleto Creek Reservoir in southeast Texas.
Three surface-water gain-loss surveys-July 29-30, 2009, January 11-13, 2010, and June 21-22, 2010 - were done under different hydrologic conditions to determine the locations and amounts of streamflow recharging or discharging from the Evangeline aquifer. During periods when flow in the reaches of the upper Coleto Creek watershed was common (such as June 2010, when 12 of 25 reaches were flowing) or likely (such as January 2010, when 22 of 25 reaches were flowing) most of the reaches appeared to be gaining; however, during droughtlike conditions (July 2009), there was virtually no streamflow in the entire upper Coleto Creek watershed. In July 2009, the only streamflow observed was in two reaches that either received inflow directly from Audilet Spring or were immediately downstream from Audilet Spring. Water levels in the Evangeline aquifer at this time seemed to have been reduced to the point that the aquifer could no longer provide sufficient quantities of water to sustain streamflow.

Groundwater-level altitudes were measured at as many as 33 different wells in the upper Coleto Creek watershed during three survey events: August 4-7 and 12, 2009; January 12-14 and 22, 2010; and June 21-24, 2010. These data were used in conjunction with groundwater-level altitudes from three wells continuously monitored by the Texas Commission of Environmental Quality to generate potentiometric surface maps for each of the three sampling events to help characterize groundwater hydrology of the Evangeline aquifer in the study area. The direction of groundwater flow shifts from southeast to east across the upper Coleto Creek watershed, roughly coinciding with the general flow direction of the main stem of Coleto Creek. Groundwater-level altitudes increased an average of 2.35 in. between the first and third sampling events as drought conditions in the summer of 2009 were followed by consistent rains the subsequent fall and winter.

A total of 44 water-quality samples were collected at 21 different sites over the course of the three sampling events. Major-ion compositions were relatively consistent among most of the samples (generally calcium bicarbonate waters, often with chloride making a major contribution), and dissolved solids concentrations were high (greater than $500 \mathrm{mg} / \mathrm{L}$ ) in 74 percent of them. Of the 23 trace elements that were analyzed in water samples as part of this study, only arsenic (in two samples) and manganese (in seven samples) had concentrations that exceeded public drinking-water standards or guidelines. Arsenic concentrations exceeded the U.S. Environmental Protection Agency (USEPA) Maximum Contaminant Level (MCL) of $10 \mu \mathrm{g} / \mathrm{L}$ in two samples (station 08177300 on Perdido Creek on June 21, 2010, and Audilet Spring on January 13, 2010), whereas manganese concentrations exceeded public drinking-water guidelines $(50 \mu \mathrm{g} / \mathrm{L})$ in both samples collected at Yorktown Creek at CR 452, both samples collected at station 08177300 on Perdido Creek, and all three samples collected at State well 79-15-904. At 3 of the 19 sites sampled-State wells 79-06-411, 79-14-204, and Audilet Spring — nitrate concentrations exceeded the threshold 
associated with anthropogenic contributions $(2.0 \mathrm{mg} / \mathrm{L})$, but all were less than the USEPA MCL. All three sites are within about a 3-mi radius surrounding Audilet Spring; all other sites within that radius exhibited slightly elevated nitrate concentrations relative to the remaining sites in the study area. The majority of the water samples (36 out of 44 ) that were analyzed for $\delta \mathrm{D}$ and $\delta^{18} \mathrm{O}$ during the three sampling events plotted in a relatively tight cluster centered near the global meteoric water line; this finding indicates that these sites are most likely not heavily influenced by evaporative processes. The eight remaining samples, which include the four surface-water samples collected in June 2010, the sample collected from Coleto Creek Reservoir site in January 2010, and all three samples collected at State well 79-15-904, deviate from the global meteoric water line in a way that indicates evaporative losses. The isotopic signatures of the three samples collected at State well 79-15-904, when taken in conjunction with its proximity to Coleto Creek Reservoir site, indicate that there is likely a hydraulic connection between the two. When all of the sites are examined as a whole, there is a pattern in strontium concentrations (as indicated by the best-fit regression line $\left.\delta^{87} \mathrm{Sr}=0.493 / \mathrm{Sr}+0.708\right)$ across the entire upper Coleto Creek watershed that might indicate both the surface-water and groundwater samples derive from a single source with relatively uniform water-rock interactions, the Evangeline aquifer.

\section{References}

Agency for Toxic Substances and Disease Registry, 2008, Toxicological profile for manganese (update): Atlanta, Ga., U.S. Public Health Service, 539 p.

Aronow, S., Brown, T.E., Brewton, J.L., Eargle, D.H., and Barnes, V.E., 1987, Geologic atlas of Texas, GA005 Beeville-Bay City sheet: Austin, University of Texas, Bureau of Economic Geology, 4 p., 1 sheet.

Ashworth, J.B., and Hopkins, Janie, 1995, Aquifers of Texas: Texas Water Development Board Report 345, 69 p.

Baertschi, P., 1976, Absolute ${ }^{18} \mathrm{O}$ content of standard mean ocean water: Earth and Planetary Science Letters, v. 31, p. 341-344.

Baker, E.T., Jr., 1979, Stratigraphic and hydrogeologic framework of part of the coastal plain of Texas: Texas Department of Water Resources Report 236, 43 p.

Bayless, E.R., Bullen, T.D., and Fitzpatrick, J.A., 2004, Use of ${ }^{87} \mathrm{Sr} /{ }^{86} \mathrm{Sr}$ and $\delta^{11} \mathrm{~B}$ to identify slag-affected sediment in southern Lake Michigan: Environmental Science \& Technology, v. 38, no. 5, p. 1330-1337.
Bruckner, M.Z., 2009, A primer on stable isotopes and some common uses in hydrology: Bozeman, Mont., Montana State University, accessed September 21, 2010, at http:// serc.carleton.edu/microbelife/research_methods/environ_ sampling/stableisotopes.html.

Bureau of Economic Geology, 1996, Physiographic map of Texas: Austin, Tex., University of Texas at Austin, 2 p.

Childress, C.J.O., Foreman, W.T., Connor, B.F., and Maloney, T.J., 1999, New reporting procedures based on longterm method detection levels and some considerations for interpretations of water-quality data provided by the U.S. Geological Survey National Water Quality Laboratory: U.S. Geological Survey Open-File Report 99-193, 19 p.

Clark, I.D., and Fritz, P., 1997, Environmental isotopes in hydrogeology: New York, Lewis Publishers, 328 p.

Connecticut Department of Public Health, 2011, Fact sheetManganese in drinking water: Drinking Water Section, accessed August 17, 2011, at http://www.ct.gov/dph/lib/dph/ drinking_water/pdf/manganese.pdf.

Coplen, T.B., Wildman, J.D., and Chen, Julie, 1991, Improvements in the gaseous hydrogen-water equilibration technique for hydrogen isotope ratio analysis: Analytical Chemistry, v. 63, p. 910-912.

Craig, Harmon, 1961, Isotopic variations in meteoric waters: Science, v. 133 , no. 3465 , p. $1702-1703$.

Cunningham, W.L., and Schalk, C.W., comps., 2011, Groundwater technical procedures of the U.S. Geological Survey: U.S. Geological Survey Techniques and Methods 1-A1, 151 p., accessed August 25, 2011, at http://pubs.usgs.gov/ tm/1a1/pdf/tm1-al.pdf.

Epstein, S., and Mayeda, T., 1953, Variation of $\mathrm{O}^{18}$ content of waters from natural sources: Geochemica et Cosmochemica Acta, v. 4, p. 213-224.

Fishman, M.J., ed., 1993, Methods of analysis by the U.S. Geological Survey National Water Quality LaboratoryDetermination of inorganic and organic constituents in water and fluvial sediments: U.S. Geological Survey OpenFile Report 93-125, 217 p.

Fishman, M.J., and Friedman, L.C., eds., 1989, Methods for determination of inorganic substances in water and fluvial sediments: U.S. Geological Survey Techniques of WaterResources Investigations, book 5, chap. A1, 545 p.

Fleming, B.J., DeJong, B.D., and Phelan, D.J., 2011, Geology, hydrology, and water quality of the Little Blackwater River watershed, Dorchester County, Maryland, 2006-09: U.S. Geological Survey Scientific Investigations Report 2011-5054, 82 p. 
Garbarino, J.R., 1999, Methods of analysis by the U.S. Geological Survey National Water Quality LaboratoryDetermination of dissolved arsenic, boron, lithium, selenium, strontium, thallium, and vanadium using inductively coupled plasma-mass spectrometry: U.S. Geological Survey Open-File Report 99-093, 31 p.

Garbarino, J.R., Kanagy, L.K., and Cree, M.E., 2006, Determination of elements in natural-water, biota, sediment and soil samples using collision/reaction cell inductively coupled plasma-mass spectrometry: U.S. Geological Survey Techniques and Methods, book 5, sec. B, chap. 1, 87 p.

Gesch, D.B., 2007, The National Elevation Dataset, in Maune, D., ed., Digital elevation model technologies and applications - The DEM users manual (2d ed.): Bethesda, Md., American Society for Photogrammetry and Remote Sensing, p. 99-118.

Gonfiantini, R., 1984, Advisory group meeting on stable isotope reference samples for geochemical and hydrological investigations, September 19-21, 1983: Vienna, International Atomic Energy Agency, Report to Director General, $77 \mathrm{p}$.

Guadalupe-Blanco River Authority, 2007, Coleto Creek Park and reservoir fact sheet, accessed October 10, 2007, at http://www.gbra.org/Recreation/ColetoCreek/Default.aspx.

Hageman, R., Nief, G., and Roth, E., 1970, Absolute D/H ratio for SMOW: Tellus, v. 22, p. 712-715.

Hem, J.D., 1985, Study and interpretation of the chemical characteristics of natural water ( $3 \mathrm{~d}$ ed.): U.S. Geological Survey Water-Supply Paper 2254, 263 p.

Kasmarek, M.C., and Robinson, J.L., 2004, Hydrogeology and simulation of ground-water flow and land-surface subsidence in the northern part of the Gulf Coast aquifer system, Texas: U.S. Geological Survey Scientific Investigations Report 2004-5102, 111 p.

Kendall, Carol, and McDonnell, J.J., eds., 1998, Isotope tracers in catchment hydrology: New York, Elsevier, 839 p.

Larkin, T.J., and Bomar, G.W., 1983, Climatic atlas of Texas: Texas Department of Water Resources, Limited Printing Report LP-192, $151 \mathrm{p}$.

Lizárraga, J.S., and Ockerman, D.J., 2010, Simulation of streamflow, evapotranspiration, and groundwater recharge in the Lower San Antonio River watershed, south-central Texas, 2000-2007: U.S. Geological Survey Scientific Investigations Report 2010-5027, $41 \mathrm{p}$.

Mace, R.E., Davidson, S.C., Angle, E.S., and Mullican, W.F. III, 2006, Aquifers of the Gulf Coast of Texas: Texas Water Development Board Report 365, 304 p.
Maugh, T.H, II, 1973, Trace elements-A growing appreciation of their effects on man: Science, v. 181, p. 253-254.

National Climatic Data Center, 2011, Weather/climate events, information and assessments-Weather/climate events, data and products: National Oceanic \& Atmospheric Administration, National Climatic Data Center Web Site, accessed August 26, 2011, at http://www.ncdc.noaa.gov/oa/ncdc. html.

Ockerman, D.J., 2002, Gain-loss study of lower San Pedro Creek and the San Antonio River, San Antonio, Texas, May-October 1999: U.S. Geological Survey Open-File Report 2002-023, 15 p.

Otero, C.L., 2007, Geologic, hydrologic, and geochemical identification of flow paths in the Edwards aquifer, northeastern Bexar and southern Comal Counties, Texas: U.S. Geological Survey Scientific Investigations Report 2007-5285, 48 p.

Patton, C.J., and Truitt, E.P., 2000, Methods of analysis by the U.S. Geological Survey National Water Quality Laboratory-Determination of ammonium plus organic nitrogen by a Kjeldahl digestion method and an automated photometric finish that includes digest cleanup by gas diffusion: U.S. Geological Survey Open-File Report 00-170, 31 p.

Proctor, C.V., Jr., Brown, T.E., Waechter, N.B., Aronow, S., and Barnes, V.E., 1974, Geologic atlas of Texas, GA0030 Seguin sheet: Austin, University of Texas, Bureau of Economic Geology, 6 p., 1 sheet.

Rantz, S.E., and others, 1982, Measurement and computation of streamflow-Volumes 1 and 2: U.S. Geological Survey Water-Supply Paper 2175, $631 \mathrm{p}$.

Rounds, S.A., 2006, Alkalinity and acid neutralizing capacity (ver. 3.0): U.S. Geological Survey Techniques of WaterResources Investigations, book 9, chap. A6, section 6.6, 56 p., available at http://pubs.water.usgs.gov/twri9A6/.

Ryder, P.D., 1996, Ground water atlas of the United StatesSegment 4, Oklahoma, Texas: U.S. Geological Survey Hydrologic Atlas 730-E, accessed August 20, 2008, at http://capp.water.usgs.gov/gwa/ch_e/E-text6.html.

Sauer, V.B., and Meyer, R.W., 1992, Determination of error in individual discharge measurements: U.S. Geological Survey Open-File Report 92-144, 21 p.

Stiff, H.A., 1951, The interpretation of chemical water analysis by means of patterns: Journal of Petroleum Technology, v. 3, p. 15 .

Texas Water Development Board, 2007, 2007 State Water Plan, accessed November 3, 2010, at http://www.twdb.state. tx.us/wrpi/swp/swp.asp. 
Texas Water Development Board, 2011, Reservoir storage summary, accessed August 1, 2011, at http://wiid.twdb.state. tx.us/ims/resinfo/BushButton/lakeStatus.asp.

Texas Water Development Board Center for Research in Water Resources, 2010, Texas evaporation download file, accessed November 30, 2010, at http://data.crwr.utexas.edu/txevap. html.

U.S. Census Bureau, 2011, Texas state and county quick facts, accessed January 25, 2011, at http://quickfacts.census.gov/ qfd/states/48000.html.

U.S. Drought Monitor, 2011, Drought monitor archives, accessed July 26, 2011, at http://droughtmonitor.unl.edu/ archive.html.

U.S. Environmental Protection Agency, 2000, Drinking water regulations and health advisories: U.S. Environmental Protection Agency Report EPA 822-B-00-001, 12 p.

U.S. Environmental Protection Agency, 2010, Current drinking-water standards: Office of Ground Water and Drinking Water, accessed November 22, 2010, at http:// www.epa.gov/safewater/mcl.html.
U.S. Geological Survey, 1980, Ground water: Office of Water Data Coordination, National Handbook of Recommended Methods for Water-Data Acquisition, chap. 2, 149 p.

U.S. Geological Survey, 1999, The quality of our Nation's waters-Nutrients and pesticides: U.S. Geological Survey Circular $1225,82 \mathrm{p}$.

U.S. Geological Survey, variously dated, National field manual for the collection of water-quality data: U.S. Geological Survey Techniques of Water-Resources Investigations, book 9, chaps. A1-A9, accessed September 20, 2010, at http:// water.usgs.gov/owq/FieldManual/.

U.S. Geological Survey, 2011, National Water Information System-U.S. Geological Survey water data for Texas, accessed July 27, 2011, at http://waterdata.usgs.gov/tx/nwis/ nwis.

Welch, A.J., Westjohn, D.B., Helsel, D.R., and Wanty, R.B., 2000, Arsenic in ground water of the United StatesOccurrence and geochemistry: Ground Water, v. 38, no. 4, p. 589-604.

World Health Organization, 2011, Chloride in drinking-water, accessed April 5, 2011, at http://www.who.int/water sanitation_health/dwq/chloride.pdf. 


\section{Appendixes}

Appendix 1. Quality control and quality assurance data, including an equipment blank and relative percent difference for sequential-replicate samples, upper Coleto Creek watershed, southeast Texas, August 2009-June 2010.

Appendix 2. Calculation of estimated evaporative losses within stream reaches, upper Coleto Creek watershed, southeast Texas, August 2009-June 2010. 
Appendix 1-1. Quality control and quality assurance data, including an equipment blank and relative percent difference for sequential-replicate samples, upper Coleto Creek watershed, southeast Texas, August 2009-June 2010.

[SR, sequential replicate; RPD, relative percent difference; E, estimated; -- , not computed or not analyzed; mg/L, milligrams per liter; ${ }^{\circ} \mathrm{C}$, degrees Celsius; $\mu \mathrm{g} / \mathrm{L}$, micrograms per liter; $<$, less than]

\begin{tabular}{|c|c|c|c|c|c|c|c|}
\hline $\begin{array}{r}\text { Station number } \\
\text { State well number }\end{array}$ & $\begin{array}{c}285616097222801 \\
79-06-411\end{array}$ & $\begin{array}{c}285616097222801 \\
79-06-411\end{array}$ & $\begin{array}{c}285616097222801 \\
79-06-411\end{array}$ & $\begin{array}{l}284518097185401 \\
79-14-804\end{array}$ & $\begin{array}{c}284518097185401 \\
79-14-804\end{array}$ & $\begin{array}{l}284518097185401 \\
79-14-804\end{array}$ & Blank \\
\hline $\begin{array}{l}\text { Date } \\
\text { Time }\end{array}$ & $\begin{array}{c}8 / 5 / 2009 \\
1200\end{array}$ & $\begin{array}{l}8 / 5 / 2009 \text { SR } \\
\quad 1201\end{array}$ & RPD & $\begin{array}{c}1 / 11 / 2010 \\
1500\end{array}$ & $\begin{array}{c}1 / 11 / 2010 \text { SR } \\
1501\end{array}$ & RPD & $\begin{array}{c}8 / 10 / 2009 \\
1403\end{array}$ \\
\hline Dissolved oxygen, water, unfiltered $(\mathrm{mg} / \mathrm{L})$ & 4.3 & 4.3 & -- & 5.8 & 5.8 & -- & -- \\
\hline $\mathrm{pH}$, water, unfiltered, field, standard units & E 6.7 & E 6.7 & -- & E 7.1 & 7.1 & -- & -- \\
\hline $\mathrm{pH}$, water, unfiltered, laboratory, standard units & 7.4 & 7.4 & -- & 7.4 & 7.5 & -- & 7.5 \\
\hline $\begin{array}{l}\text { Specific conductance, water, unfiltered, laboratory, } \\
\text { microsiemens per centimeter at } 25^{\circ} \mathrm{C}\end{array}$ & 996 & 998 & -- & 715 & 712 & -- & $<5$ \\
\hline $\begin{array}{l}\text { Specific conductance, water, unfiltered, microsie- } \\
\text { mens per centimeter at } 25^{\circ} \mathrm{C}\end{array}$ & 979 & 979 & -- & 726 & 726 & -- & -- \\
\hline Temperature, water ${ }^{\circ} \mathrm{C}$ & 24.5 & 24.5 & -- & 24.4 & 24.4 & -- & -- \\
\hline $\begin{array}{l}\text { Turbidity, water, unfiltered, formazin nephelometric } \\
\text { units (FNU) }\end{array}$ & 2.7 & 2.7 & -- & 16 & 16 & -- & -- \\
\hline $\begin{array}{l}\text { Dissolved solids dried at } 180^{\circ} \mathrm{C} \text {, water, filtered } \\
(\mathrm{mg} / \mathrm{L})\end{array}$ & 586 & 583 & 0.51 & 449 & 460 & 2.42 & 10 \\
\hline Hardness, water (mg/L as $\mathrm{CaCO}_{3}$ ) & 285 & 296 & 3.79 & 241 & 245 & 1.65 & $<.10$ \\
\hline $\begin{array}{l}\text { Noncarbonate hardness, water, filtered, field } \\
\qquad\left(\mathrm{mg} / \mathrm{L} \text { as } \mathrm{CaCO}_{3}\right)\end{array}$ & 25 & 36 & 36.07 & -- & -- & -- & -- \\
\hline Calcium, water, filtered (mg/L) & 92.8 & 96.8 & 4.22 & 75.4 & 76.6 & 1.58 & $<.02$ \\
\hline Magnesium, water, filtered $(\mathrm{mg} / \mathrm{L})$ & 12.9 & 13.2 & 2.30 & 12.5 & 12.9 & 3.15 & $<.012$ \\
\hline Potassium, water, filtered (mg/L) & 4.22 & 4.44 & 5.08 & 2.96 & 3.00 & 1.34 & $<.06$ \\
\hline Sodium adsorption ratio, water, number & 2.23 & 2.24 & .45 & 1.46 & 1.44 & 1.38 & -- \\
\hline Sodium, water, filtered (mg/L) & 86.6 & 88.5 & 2.17 & 51.9 & 51.9 & 0 & $<.12$ \\
\hline Alkalinity, water, filtered, field $\left(\mathrm{mg} / \mathrm{L}\right.$ as $\left.\mathrm{CaCO}_{3}\right)$ & 260 & 260 & 0 & 274 & 267 & 2.59 & -- \\
\hline Bicarbonate, water, filtered, field (mg/L) & 317 & 317 & 0 & 334 & 325 & 2.73 & -- \\
\hline Bromide, water, filtered (mg/L) & .49 & .45 & 8.51 & .18 & .18 & 0 & $<.02$ \\
\hline Carbon dioxide, water, unfiltered $(\mathrm{mg} / \mathrm{L})$ & E 96 & E 96 & -- & E 39 & 38 & -- & -- \\
\hline Carbonate, water, filtered, field (mg/L) & $<1$ & $<1$ & -- & $<1$ & $<1$ & -- & -- \\
\hline Chloride, water, filtered (mg/L) & 133 & 133 & 0 & 59.4 & 59.3 & .17 & $<.12$ \\
\hline Fluoride, water, filtered $(\mathrm{mg} / \mathrm{L})$ & .53 & .54 & 1.87 & .65 & .67 & 3.03 & $<.08$ \\
\hline Silica, water, filtered $\left(\mathrm{mg} / \mathrm{L}\right.$ as $\left.\mathrm{SiO}_{2}\right)$ & 43.8 & 46.0 & 4.90 & 45.3 & 46.2 & 1.97 & $<.02$ \\
\hline Sulfate, water, filtered (mg/L) & 27.8 & 27.8 & 0 & 19.9 & 20.0 & .50 & $<.18$ \\
\hline
\end{tabular}


Appendix 1-1. Quality control and quality assurance data, including an equipment blank and relative percent difference for sequential-replicate samples, upper Coleto Creek watershed, southeast Texas, August 2009-June 2010.-Contined

[SR, sequential replicate; RPD, relative percent difference; E, estimated; nc, not computed or not analyzed; mg/L, milligrams per liter; ${ }^{\circ} \mathrm{C}$, degrees Celsius; $\mu \mathrm{g} / \mathrm{L}$, micrograms per liter; <, less than]

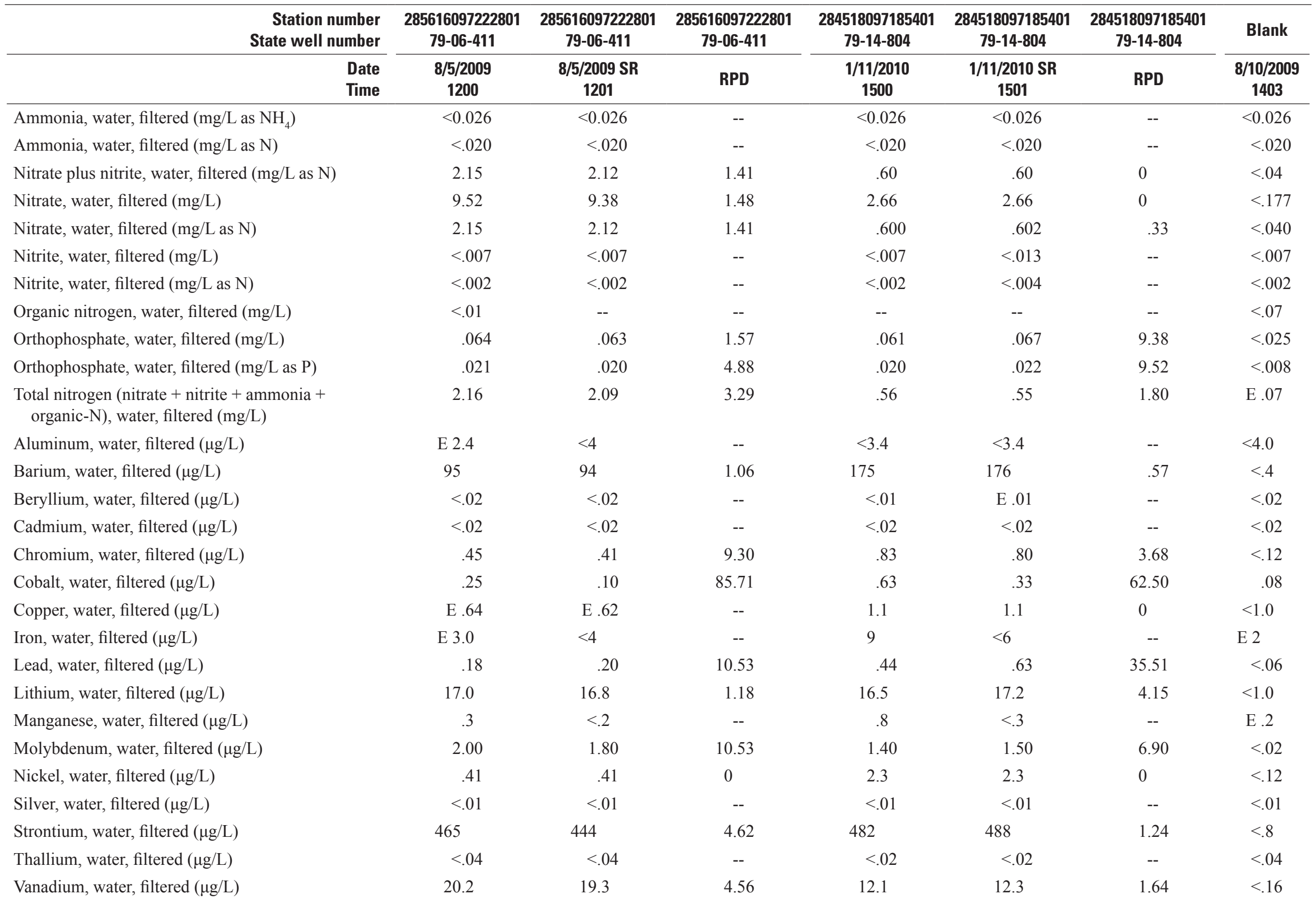


Appendix 1-1. Quality control and quality assurance data, including an equipment blank and relative percent difference for sequential-replicate samples, upper Coleto Creek watershed, southeast Texas, August 2009-June 2010.-Contined

[SR, sequential replicate; RPD, relative percent difference; E, estimated; nc, not computed or not analyzed; $\mathrm{mg} / \mathrm{L}$, milligrams per liter; ${ }^{\circ} \mathrm{C}$, degrees Celsius; $\mu \mathrm{g} / \mathrm{L}$, micrograms per liter; $<$, less than]

\begin{tabular}{|c|c|c|c|c|c|c|c|}
\hline $\begin{array}{l}\text { Station number } \\
\text { State well number }\end{array}$ & $\begin{array}{c}285616097222801 \\
79-06-411\end{array}$ & $\begin{array}{c}285616097222801 \\
79-06-411\end{array}$ & $\begin{array}{c}285616097222801 \\
79-06-411\end{array}$ & $\begin{array}{l}284518097185401 \\
79-14-804\end{array}$ & $\begin{array}{c}284518097185401 \\
79-14-804\end{array}$ & $\begin{array}{c}284518097185401 \\
79-14-804\end{array}$ & Blank \\
\hline $\begin{array}{l}\text { Date } \\
\text { Time }\end{array}$ & $\begin{array}{l}8 / 5 / 2009 \\
1200\end{array}$ & $\begin{array}{l}\text { 8/5/2009 SR } \\
1201\end{array}$ & RPD & $\begin{array}{l}1 / 11 / 2010 \\
1500\end{array}$ & $\begin{array}{c}1 / 11 / 2010 \text { SR } \\
1501\end{array}$ & RPD & $\begin{array}{l}8 / 10 / 2009 \\
1403\end{array}$ \\
\hline Zinc, water, filtered $(\mu \mathrm{g} / \mathrm{L})$ & 2.0 & E 1.9 & -- & E 1.6 & $<2.8$ & -- & $<2.0$ \\
\hline Antimony, water, filtered $(\mu \mathrm{g} / \mathrm{L})$ & E.02 & $<.04$ & -- & .06 & E .03 & -- & $<.04$ \\
\hline Arsenic, water, filtered $(\mu \mathrm{g} / \mathrm{L})$ & 2.9 & 2.8 & 3.51 & 1.7 & 1.8 & 5.71 & $<.06$ \\
\hline Boron, water, filtered $(\mu \mathrm{g} / \mathrm{L})$ & 140 & 134 & 4.38 & 147 & 138 & 6.32 & $<4$ \\
\hline Selenium, water, filtered $(\mu \mathrm{g} / \mathrm{L})$ & 2.0 & 2.0 & 0 & .92 & .94 & 2.15 & $<.06$ \\
\hline Uranium (natural), water, filtered $(\mu \mathrm{g} / \mathrm{L})$ & 1.90 & 1.78 & 6.52 & 1.63 & 1.64 & .61 & $<.01$ \\
\hline Deuterium/Protium ratio, water, unfiltered, per mil & -22.60 & -23.30 & -3.05 & -24.30 & -23.40 & -3.77 & -- \\
\hline $\begin{array}{l}\text { Oxygen-18/Oxygen-16 ratio, water, unfiltered, } \\
\text { per mil }\end{array}$ & -4.24 & -4.25 & -.24 & -4.18 & -4.25 & -1.66 & -- \\
\hline $\begin{array}{l}\text { Strontium-87/Strontium- } 86 \text { ratio, water, filtered, } \\
\text { per mil }\end{array}$ & .70916 & .70915 & 0 & .70905 & .70909 & .01 & -- \\
\hline
\end{tabular}


Appendix 2-1. Calculation of estimated evaporative losses within stream reaches, upper Coleto Creek watershed, southeast Texas, June 2009.

[km, kilometers; $\mathrm{ft}$, feet; in/d, inches per day; $\mathrm{ft} / \mathrm{s}$, feet per second; $\mathrm{ft} / \mathrm{s}$, cubic feet per second]

\begin{tabular}{|c|c|c|c|c|c|c|c|c|}
\hline Reach & $\begin{array}{c}\text { Reach } \\
\text { length } \\
(\mathbf{k m})\end{array}$ & $\begin{array}{c}\text { Reach } \\
\text { length } \\
\text { (ft) }\end{array}$ & $\begin{array}{l}\text { Stream width } \\
\text { at upstream } \\
\text { boundary of } \\
\text { reach } \\
\text { (ft) }\end{array}$ & $\begin{array}{l}\text { Stream width } \\
\text { at downstream } \\
\text { boundary of } \\
\text { reach } \\
\text { (ft) }\end{array}$ & $\begin{array}{l}\text { Average } \\
\text { stream width } \\
\text { for entire } \\
\text { reach } \\
\text { (ft) }\end{array}$ & $\begin{array}{l}\text { Evaporative } \\
\text { loss } \\
\text { (in/d) }\end{array}$ & $\begin{array}{l}\text { Evaporative } \\
\text { loss } \\
\text { (ft/s) }\end{array}$ & $\begin{array}{c}\text { Estimated } \\
\text { evaporation } \\
\text { loss within } \\
\text { reach } \\
\left(\mathrm{ft}^{3} / \mathrm{s}\right)\end{array}$ \\
\hline $\mathrm{C} 1$ & 5.828 & 19,121 & 0 & 0 & 0 & 0.17 & 0.00000017 & 0 \\
\hline $\mathrm{C} 2$ & 5.694 & 18,681 & 0 & 0 & 0 & .17 & .00000017 & 0 \\
\hline $\mathrm{C} 3$ & 7.022 & 23,038 & 0 & 0 & 0 & .17 & .00000017 & 0 \\
\hline $\mathrm{C} 4$ & 17.07 & 56,004 & 0 & 0 & 0 & .17 & .00000017 & 0 \\
\hline $\mathrm{C} 5$ & 14.06 & 46,129 & 0 & 0 & 0 & .17 & .00000017 & 0 \\
\hline $\mathrm{C} 6$ & 16.729 & 54,885 & 0 & 0 & 0 & .17 & .00000017 & 0 \\
\hline $\mathrm{C} 7$ & 17.215 & 56,480 & 0 & 0 & 0 & .17 & .00000017 & 0 \\
\hline $\mathrm{C} 8$ & 8.761 & 28,743 & 0 & 0 & 0 & .17 & .00000017 & 0 \\
\hline C9 & 7.662 & 25,138 & 0 & 2.2 & 1.1 & .17 & .00000017 & .00458 \\
\hline $\mathrm{C} 10$ & 7.922 & 25,991 & 2.2 & 0 & 1.1 & .17 & .00000017 & .00473 \\
\hline $\begin{array}{c}\text { C11 and } \\
\text { C14 }\end{array}$ & 12.136 & 39,816 & 0 & 0 & 0 & .17 & .00000017 & 0 \\
\hline $\mathrm{C} 12$ & 10.445 & 34,268 & 0 & 0 & 0 & .17 & .00000017 & 0 \\
\hline $\mathrm{C} 13$ & 8.893 & 29,177 & 0 & 0 & 0 & .17 & .00000017 & 0 \\
\hline $\mathrm{C} 15$ & 12.29 & 40,322 & 0 & 0 & 0 & .17 & .00000017 & 0 \\
\hline $\mathrm{C} 16$ & 16.367 & 53,698 & 0 & 0 & 0 & .17 & .00000017 & 0 \\
\hline $\mathrm{C} 17$ & 9.851 & 32,320 & 0 & 0 & 0 & .17 & .00000017 & 0 \\
\hline $\mathrm{C} 18$ & 4.838 & 15,873 & 0 & 0 & 0 & .17 & .00000017 & 0 \\
\hline C19 & 14.742 & 48,366 & 0 & 0 & 0 & .17 & .00000017 & 0 \\
\hline $\mathrm{C} 20$ & 9.214 & 30,230 & 0 & 0 & 0 & .17 & .00000017 & 0 \\
\hline $\mathrm{C} 21$ & 6.026 & 19,770 & 0 & 0 & 0 & .17 & .00000017 & 0 \\
\hline $\mathrm{C} 22$ & 7.481 & 24,544 & 0 & 0 & 0 & .17 & .00000017 & 0 \\
\hline $\mathrm{T} 1$ & 11.593 & 38,035 & 0 & 0 & 0 & .17 & .00000017 & 0 \\
\hline $\mathrm{P} 1$ & 14.838 & 48,681 & 0 & 0 & 0 & .17 & .00000017 & 0 \\
\hline P2 & 13.088 & 42,940 & 0 & 0 & 0 & .17 & .00000017 & 0 \\
\hline
\end{tabular}


Appendix 2-2. Calculation of estimated evaporative losses within stream reaches, upper Coleto Creek watershed, southeast Texas, January 2010.

[km, kilometers; $\mathrm{ft}$, feet; in/d, inches per day; $\mathrm{ft} / \mathrm{s}$, feet per second; $\mathrm{ft}^{3} / \mathrm{s}$, cubic feet per second]

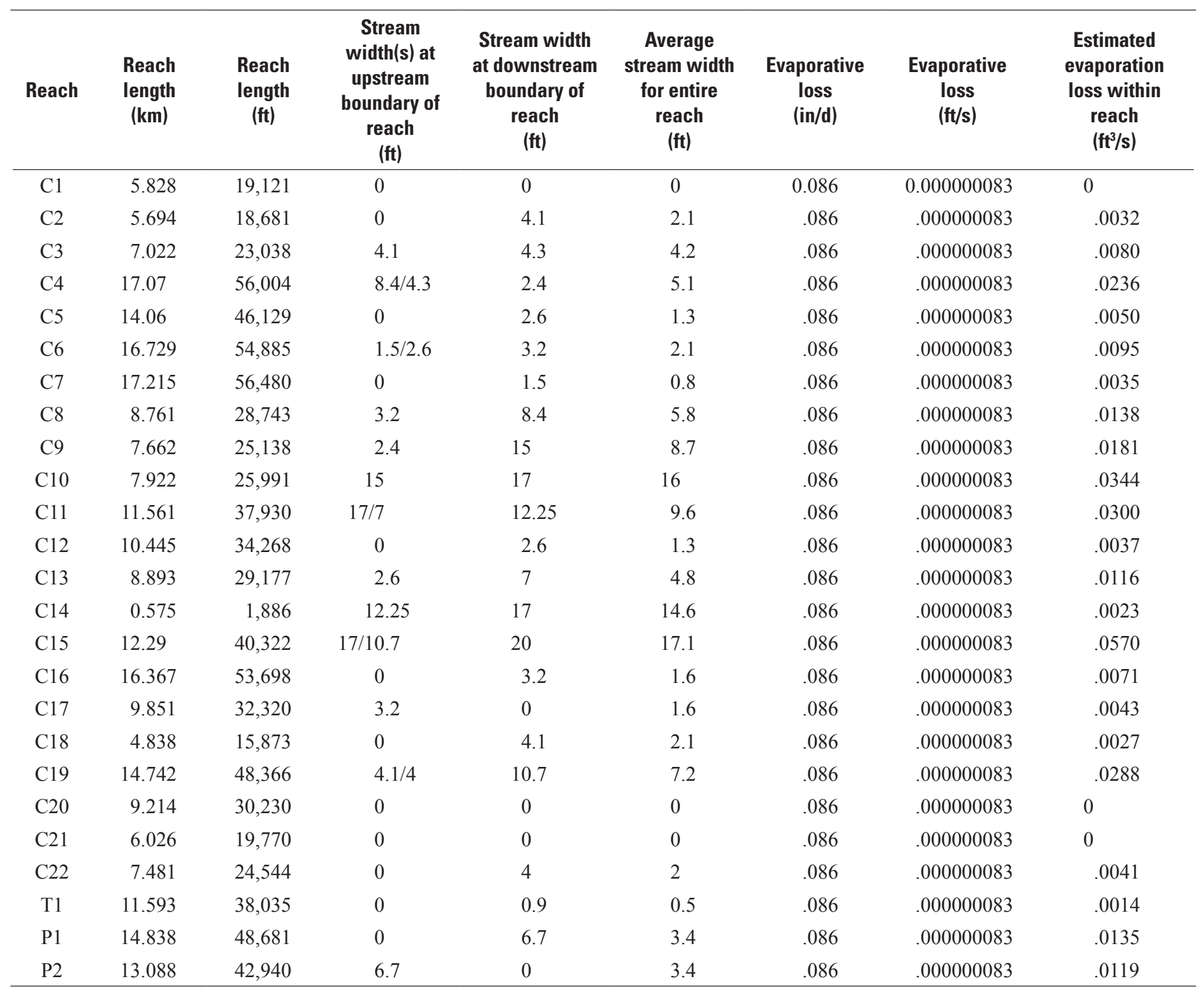


Appendix 2-3. Calculation of estimated evaporative losses within stream reaches, upper Coleto Creek watershed, southeast Texas, June 2010.

[km, kilometers; $\mathrm{ft}$, feet; in/d, inches per day; ft/s, feet per second; $\mathrm{ft}^{3} / \mathrm{s}$, cubic feet per second]

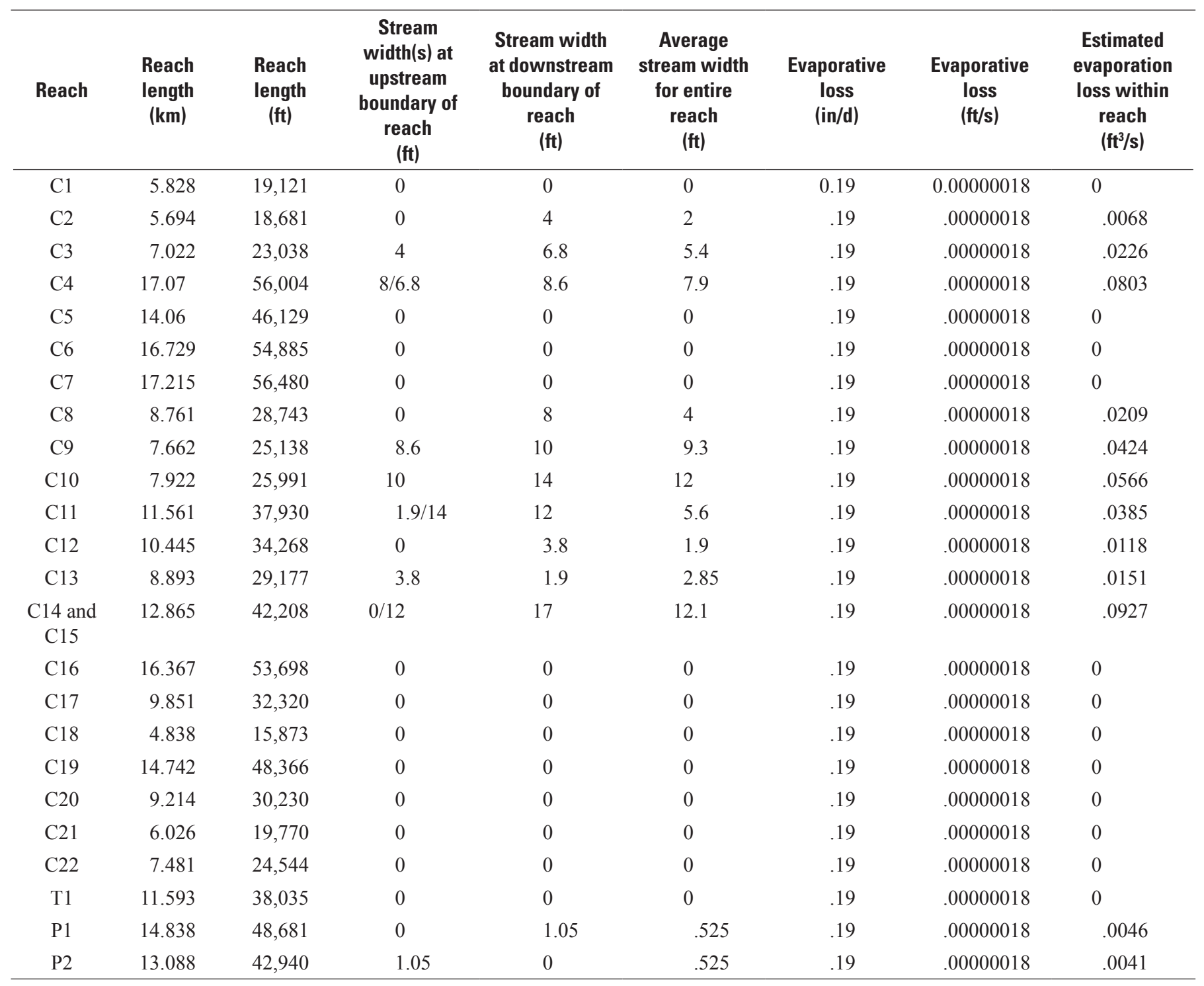


Publishing support provided by the: Lafayette and Rolla Publishing Service Centers

For more information concerning this publication, contact: Director, Texas Water Science Center U.S. Geological Survey

1505 Ferguson Lane

Austin, TX 78754-4733

(512) $927-3500$

Or visit the Texas Water Science Center Web site at: http://tx.usgs.gov/ 

